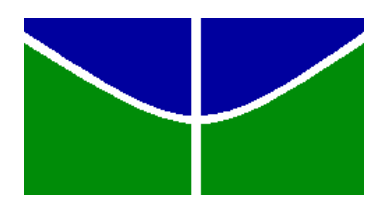

Universidade de Brasília - UnB

Instituto de Ciências Humanas - IH

Departamento de Serviço Social - SER

SARAH DE OLIVEIRA NASCIMENTO MEDEIROS

Matrícula: 00/63720

\title{
A EDUCAÇÃO EM DIREITOS HUMANOS NO PROJETO POLÍTICO-PEDAGÓGICO DO CENTRO DE ENSINO FUNDAMENTAL 01 DE SOBRADINHO/DF
}


SARAH DE OLIVEIRA NASCIMENTO MEDEIROS

\section{A EDUCAÇÃO EM DIREITOS HUMANOS NO PROJETO POLÍTICO-PEDAGÓGICO DO CENTRO DE ENSINO FUNDAMENTAL 01 DE SOBRADINHO/DF}

Monografia apresentada como requisito para a conclusão do curso de Bacharel em Serviço Social da Universidade de Brasília - UnB.

Orientadora: Prof ${ }^{a}$. Dr ${ }^{\mathrm{a}}$. Nair Heloisa Bicalho de Sousa

Universidade de Brasília - UnB

Brasília - 2008 


\section{RESUMO}

A educação em direitos humanos constitui pré-requisito indispensável à cidadania e à construção de uma cultura em direitos humanos. A cidadania é definida, contemporaneamente, como uma prática de ressignificação, desencadeada pelos conflitos de interpretação engendrada por políticas culturais. A luta pelos direitos humanos constitui um grande desafio que depende de práticas pedagógicas e projetos participativos que promovam a organização do trabalho pedagógico da escola de forma a favorecer a formação de cidadãos e a construção de valores. Este trabalho tem como foco de interesse a investigação da educação em direitos humanos no projeto político-pedagógico do Centro de Ensino Fundamental 01 de Sobradinho, DF.

Palavras-chave: Educação, Direitos humanos, Projeto político-pedagógico, Educação em direitos humanos. 


\section{SUMÁRIO}

1- APRESENTAÇ̃̃O

2- JUSTIFICATIVA.

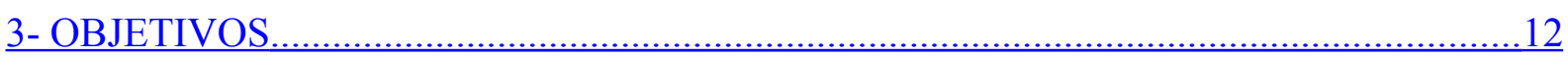

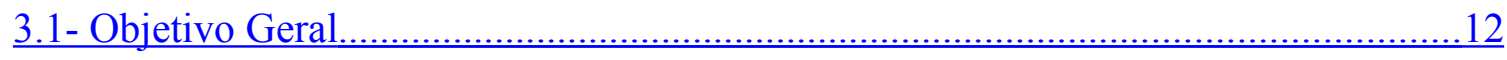

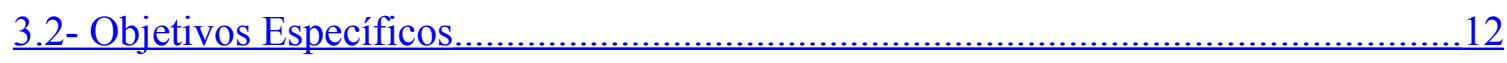

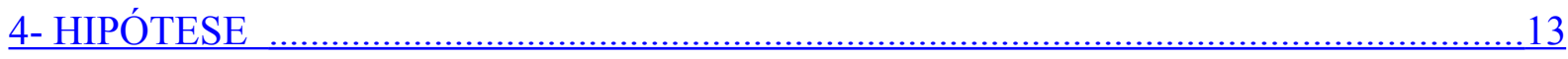

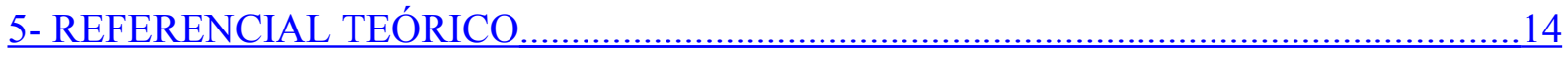

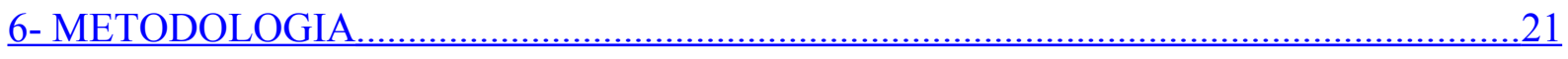

7- ESTUDO DE CASO: Centro de Ensino Fundamental 01 de Sobradinho DF - CEF 01....24

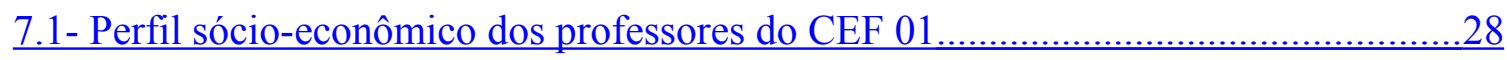

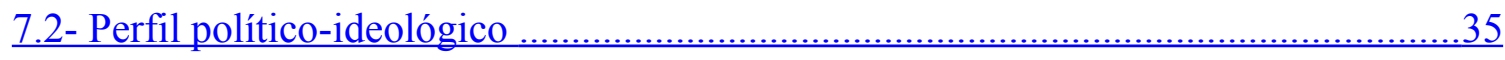

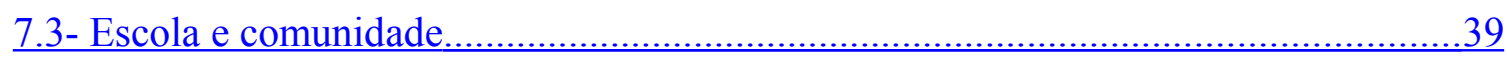

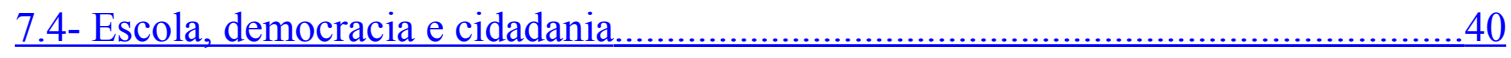

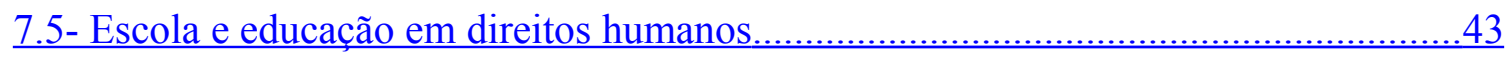


Ao analisar o PPP do CEF 01 pode-se perceber que, longe de possuir a intenção de esgotar a discussão do tema e de entender completamente o universo pesquisado como um todo, para além de suas relações e construções sociais bem como institucionais, foi possível verificar que o tema educação em direitos humanos encontra-se diluído em diversos projetos da escola, mas não de maneira sistematizada em ações ou projetos específicos. Há pouca clareza quanto à educação em direitos humanos, apesar de haver forte intenção, por parte do corpo docente, de transmitir valores e formar cidadãos

$\underline{\text { A avaliação continuada do PPP é positiva, visto que ainda há bastante o que acrescentar e }}$ rever nas práticas pedagógicas dos docentes e, visto que a construção coletiva deste projeto indica a possibilidade de agregação de outros que visem à formação de cidadãos como $\underline{\text { sujeitos de direitos, conhecedores dos seus deveres, solidários e capazes de refletirem a }}$ $\underline{\text { respeito da realidade social em que estão inseridos e, de maneira mais profunda, contribuírem }}$ para uma mudança dessa realidade.

O conhecimento do Plano Nacional de Educação em Direitos Humanos por parte dos professores, e a conscientização clara de que a educação em direitos humanos tem por objetivo a formação de uma cultura de respeito à dignidade humana, através da promoção e da vivência de valores como igualdade, justiça, solidariedade, cooperação, liberdade, tolerância e paz são de fundamental importância à construção de um projeto político-pedagógico que realmente contemple de maneira satisfatória a educação em direitos humanos. 


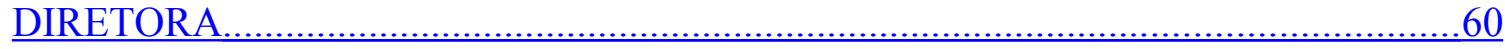

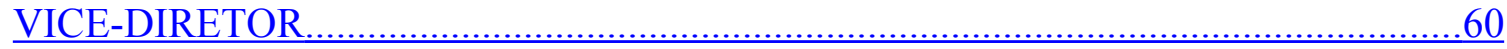

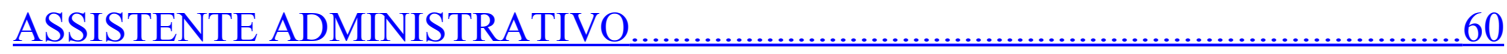

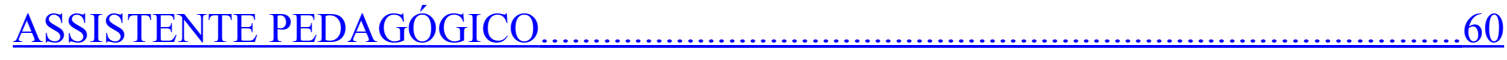

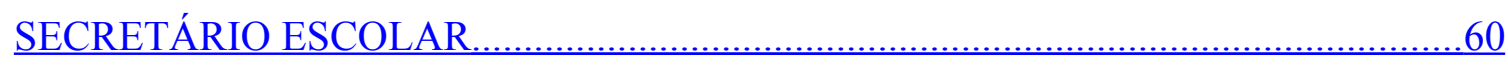

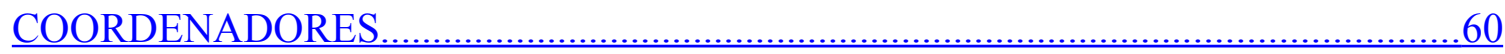




\section{1- APRESENTAÇÃO}

Nas disciplinas Pesquisa em Serviço Social I e II, ministradas pela Prof ${ }^{a}$. Dr ${ }^{a}$. Nair Heloísa Bicalho de Sousa, o tema da educação em direitos humanos foi amplamente explorado e deu origem a uma pesquisa sobre os projetos político-pedagógicos de escolas públicas em Brasília - DF. O foco da pesquisa tinha como referência a proposta do Plano Nacional de Educação em Direitos Humanos (PNEDH) lançado em versão preliminar pela Secretaria Especial de Direitos Humanos em 2003.

Em dois estudos de caso realizados em Brasília foi possível observar que os alunos não estavam acessando conhecimentos a respeito deste tema por meio do currículo e da vivência escolar, apesar dos projetos político-pedagógicos possuírem ações e diretrizes que contemplassem o tema. Isto despertou meu interesse em dar continuidade à pesquisa sobre a educação em direitos humanos em uma escola localizada em Sobradinho, cidade satélite do Distrito Federal.

O PNEDH define a educação em direitos humanos como:

"um processo sistemático e multidimensional que orienta a formação do sujeito de direitos, articulando as seguintes dimensões: apreensão de conhecimentos historicamente construídos sobre os direitos humanos e a sua relação com os contextos internacional, nacional e local; afirmação de valores, atitudes e práticas sociais que expressam a cultura dos direitos humanos em todos os espaços da sociedade; formação de uma consciência cidadã capaz de se fazer presente nos níveis cognitivo, social, ético e político; desenvolvimento de processos metodológicos participativos e de construção coletiva - utilizando linguagens e materiais didáticos orientados à mudança de mentalidade - bem como práticas individuais e sociais que gerem ações e instrumentos em favor da defesa, promoção e ampliação dos direitos humanos." (Comitê Nacional de Educação em Direitos Humanos, 2006, p. 07) 
Com base nesta definição, a educação em direitos humanos configura-se como pré-requisito indispensável para o acesso a diversos outros direitos, além de favorecer o respeito diante de grupos socialmente excluídos, e também de capacitar o cidadão para exercer a cidadania plena.

Este trabalho tem como eixo de interesse a investigação da educação em direitos humanos no projeto político-pedagógico do Centro de Ensino Fundamental 01 de Sobradinho, DF. 


\section{2- JUSTIFICATIVA}

"Educar é impregnar de sentido cada ato do cotidiano é um processo coletivo, recíproco e horizontal de cultivo do potencial das pessoas para torná-las conscientes, cidadãs pensantes, capazes de problematizar a realidade, de sentir as injustiças e as desigualdades como afrontas à sua própria dignidade e, partindo dos aspectos estruturais da sociedade, ser capaz de transformá-la.” (FREIRE, 1970)

Para a democracia ser efetiva em todos os campos da sociedade, é imprescindível combiná-la com a educação em direitos humanos, pois ela fortalece e auxilia na organização da sociedade civil, à medida que favorece a construção de uma cidadania plena.

O processo de aprendizado se dá durante toda existência dos indivíduos e é construído coletivamente. No entanto, a escola constitui um espaço privilegiado e propício ao aprendizado. O governo brasileiro tem conforme a Constituição de 1998, o compromisso de promover uma educação de qualidade universal como direito, por meio de ações fundamentais como a universalização do ensino fundamental, a ampliação da educação infantil, a expansão do ensino médio e da educação superior, além da melhoria da qualidade da educação.

No Brasil, a luta pelos direitos humanos surgiu como uma resposta às diversas formas de violência sofridas no período da ditadura militar, principalmente nas décadas de 1960 e 1970. Assim, durante a redemocratização dos anos 1980, diversos debates e seminários além da intensa mobilização social, surgiram com a intenção de criar uma nova cultura política que preservasse, dentre outras premissas, a defesa dos direitos humanos e a construção da cidadania. Em 1988 a Constituição Federal é promulgada contendo normas de 
defesa dos direitos humanos e de promoção da cidadania, recebendo inclusive o apelido de “Constituição Cidadã”.

A Organização das Nações Unidas - ONU - estabeleceu entre 1995 e 2004 a Década da Educação em Direitos Humanos. O objetivo central era possibilitar que governos e sociedades civis fossem estimulados a criar um ambiente propício à formulação e implementação de projetos e programas de educação em direitos humanos ao nível internacional.

No âmbito nacional, em 2003 surgiu a primeira versão do Plano Nacional de Educação em Direitos Humanos (PNEDH), que orientava a construção de ações e programas comprometidos com uma cultura de justiça social e paz.

Em 2006, após a sistematização das contribuições oriundas dos encontros estaduais de educação, houve apresentação dessas propostas ao Comitê Nacional de Educação em Direitos Humanos (CNEDH), em seminário para apreciação e análise e desse modo foi feita a revisão da versão preliminar do PNEDH, a qual foi posteriormente submetida à consulta pública, via internet para sua versão definitiva. "Esta versão se destaca como política pública em dois sentidos principais: primeiro, como proposta de um projeto de sociedade baseada nos princípios da democracia e da justiça social; segundo, como construção de uma cultura de direitos humanos, entendida como processo a ser apreendido e vivenciado numa perspectiva de cidadania ativa." 1

Em suas linhas de ação, o PNEDH define como prioritário o desenvolvimento normativo e institucional; a produção de informação e conhecimento; a realização de parcerias e intercâmbios internacionais, ampliando o acesso às ações de educação em direitos humanos às pessoas com necessidades especiais; a formação e capacitação de profissionais de

\footnotetext{
${ }^{1}$ Brasil. Comitê Nacional de Educação em Direitos Humanos. Plano Nacional de Educação em Direitos Humanos. Brasília: Secretaria Especial dos Direitos Humanos, Ministério da Educação, Ministério da Justiça, UNESCO, 2007.
} 
maneira contínua, introduzindo o tema de forma interdisciplinar e transdisciplinar; a gestão de projetos e programas os quais devem ser previstos no orçamento da União, dos estados e dos municípios, visando implementar o PNEDH e, por fim, a avaliação e o monitoramento sistemático dos programas, projetos e ações de direitos humanos direcionados para as áreas do PNEDH, bem como a elaboração de relatórios dessas avaliações.

Partindo do princípio de que não existe cidadania sem a educação em direitos humanos e a construção de uma cultura a respeito desses direitos, posto que a cidadania se define contemporaneamente como uma prática de ressignificação, desencadeada pelos conflitos de interpretação engendrada por políticas culturais, justifica-se esta pesquisa como um instrumento para verificar se há, verdadeiramente, no CEF 01 de Sobradinho, um projeto político-pedagógico (PPP) comprometido com este tema e se este projeto tem, efetivamente, sido expresso nos discursos e práticas dos professores no que diz respeito à tolerância, à solidariedade, ao respeito e à paz. 


\section{3- OBJETIVOS}

\section{1- Objetivo Geral}

Investigar o projeto político-pedagógico do Centro de Ensino Fundamental 01 de Sobradinho - DF (CEF 01), tendo em vista seu comprometimento com a educação em direitos humanos.

\section{2- Objetivos Específicos}

$\checkmark$ Finalidade da escola: verificar em que medida a escola, por meio de seu projeto político-pedagógico, contribui para a formação social, cultural, política, profissional e humana dos alunos, assim como esse projeto encontra-se em conformidade com as propostas do Plano Nacional de Educação em Direitos Humanos.

$\checkmark$ Currículo: analisar os valores presentes no currículo de modo a conhecer se estes estão voltados para uma orientação emancipatória dos alunos.

$\checkmark$ Estrutura organizacional: analisar a estrutura administrativa (gestão de recursos humanos, físicos, financeiros) e pedagógica da escola (constituição e distribuição de poder, ensino/aprendizagem).

$\checkmark$ Processo de decisão: verificar se há um processo decisório democrático e participativo que envolva pais, direção, professores e alunos.

$\checkmark$ Relações de trabalho: pesquisar sobre a natureza das condições de trabalho na escola.

$\checkmark$ Avaliação: conhecer o processo de avaliação existente na escola. 


\section{4- HIPÓTESE}

Apesar do PPP do CEF 01 contemplar o tema da cidadania e da formação de valores morais junto aos alunos, falta na sua concepção e implementação, uma definição clara da educação em direitos humanos e uma articulação do corpo docente com esta proposta. 


\section{5- REFERENCIAL TEÓRICO}

Os direitos humanos balizam as ações dos cidadãos, abrangendo o campo ético, político, jurídico e os assuntos cotidianos, visando formação de sujeitos titulares de direitos, autônomos e passíveis de se libertarem da situação de opressão "a sua inserção lúcida na realidade, na situação histórica, que a levou (a pessoa oprimida) à crítica desta mesma situação e ao ímpeto de transformá-la" (FREIRE, 1970, p.19). O autor acrescenta que o educando é, juntamente com o educador, sujeito do processo de transformação da realidade e o diálogo entre ambos configura-se como a principal ferramenta deste processo. Assim, o método deixa de ser instrumento exclusivo do educador e passa a não mais representar manipulação por parte deste (verticalização do conhecimento), mas uma troca ente os dois personagens da educação: educador e educando.

A educação não sistemática, segundo Paulo Freire, possui a capacidade de efetivar seu papel transformador da realidade tendo como principais parceiros os sujeitos oprimidos, em contraponto com a educação sistemática, que serve integralmente à estrutura dominante e à manutenção da distância entre opressor (sujeito detentor do conhecimento) e oprimido (sujeito dependente do conhecimento do opressor).

Quando Freire (1970) afirma que "educar-se é impregnar de sentido cada ato do cotidiano" dialoga perfeitamente com Candau (2006) na necessidade urgente de se construir uma cultura dos direitos humanos a partir do cotidiano, por meio de uma profunda transformação dos valores e comportamentos, visando à adoção de novas práticas sociais e à construção da cidadania e da democracia a partir da educação e da prática dos direitos humanos. A autora afirma que é necessário trabalhar o cotidiano em toda sua complexidade para promover uma transformação da realidade e a principal ferramenta para é a educação em direitos humanos. 
O processo educativo precisa levar em conta o contexto social em que os educandos estão inseridos. A prática educativa deve afirmar uma pedagogia que promova convicções firmes e conscientes de que as violações não são fenômenos naturais, mas realidades construídas historicamente, e deve ser expressa na forma de trabalhar a dimensão ética da educação.

A Declaração Universal dos Direitos Humanos, no seu artigo 26, estabelece a educação como direito. Em seu preâmbulo, a implementação dos direitos humanos fica vinculada à intervenção educativa. A escola e o professorado são, dessa forma, convocados a exercer um papel-chave na divulgação dos direitos humanos. "Sem educação não se realizam os direitos humanos” (Warat). Com base nesta visão, Warat defende ainda “... uma educação desde e para os direitos humanos que impulsione e ajude as pessoas para que aprendam desde pequenas a conviver com conflitos e resolvê-los de forma positiva, não coercitiva, sem as imprevisões de violência".

A Declaração Universal dos Direitos Humanos convoca a escola a exercer a formação em direitos humanos para que ocorra o crescimento dos indivíduos e a emergência de sua cidadania. O grande desafio é a correspondência eficaz entre leis e ações. Candau (2006) sustenta que a educação em direitos humanos é de extrema importância para a construção de uma sociedade verdadeiramente democrática no Brasil e na América Latina. Enfatiza a educação como instrumento capaz de fortalecer a sociedade civil e construir alternativas viáveis, orientadas a uma cidadania plena e a um novo modelo de sociedade, onde todos tenham "o direito a ter direitos", avançando para um compromisso de mudança estrutural capaz de construir uma sociedade inclusiva.

Para Horta (2000), educar em direitos humanos supõe considerar a vida cotidiana como referência permanente da ação educacional: a) em sala de aula, suscitar um encontro relacional e sensível com a realidade do ambiente; b) abrir ao máximo o campo 
perceptivo dos alunos, chamando-os a comparecerem abertos às realidades perceptivas que os envolvem e se integram à sua experiência cotidiana; c) considerar apenas as aprendizagens adquiridas em conexão com a vida real como as que se integram verdadeiramente à personalidade, transformando-se em caminhos e desafios; d) empreender com os alunos um trabalho de educação e reeducação da percepção, capaz de desenvolver capacidades sensoriais e perceptivas que os desperte para um tipo de presença curiosa, interessada e crítica diante do que acontece em sua realidade.

Sua proposta é uma alternativa crítica ao modelo dominante, centrado em um tipo de percepção estereotipada da realidade, claramente despersonalizante e massificadora, que uniformiza e pretende obter uma adaptação submissa, convidando ao conformismo e oferecendo uma percepção parcial das situações. Deve haver compromisso com a vida por meio de um projeto alternativo, capaz de encarar a felicidade e a dignidade como direito de todos. Educar em direitos humanos não se limita a um trabalho com indivíduos isolados, que tomam consciência de seus problemas e tendem a procurar solução para eles, mas abrange conjuntos de pessoas que, coletivamente, se dão conta do efeito multiplicador e do poder que a tomada de consciência coletiva adquire.

Santiago (2004) aponta a luta pelos direitos humanos como um grande desafio, pois depende de práticas pedagógicas por meio de projetos participativos, que visam às resoluções de conflitos de forma cordial, onde temas cotidianos como discriminação, racismo, exclusão e opressão seriam tratados com uma pedagogia que busca a necessária adequação da instituição escolar às mudanças socioculturais e político-econômicas desse século.

O PPP é um instrumento importantíssimo das escolas, que visa melhorar a qualidade do ensino por meio da organização do trabalho pedagógico da escola, que é pensado e desenvolvido de acordo com sua realidade específica para fortalecer as relações 
entre a escola e o sistema de ensino como um todo. Projeto, conforme Veiga (2004) significa projetar, lançar para diante, pressupõe ruptura com o presente e promessas para o futuro. É constituído para buscar, coletivamente, arcar com as demandas internas exclusivas da escola; é político porque é democraticamente articulado com interesses sócio-políticos da população e visa à formação de um cidadão para um tipo de sociedade e é pedagógico porque visa à formação do cidadão participativo, criativo, responsável, comprometido e crítico por meio da educação em uma escola que possua os atributos necessários para promover essa construção.

Acrescenta ainda que o PPP deve ser construído e desenvolvido de acordo com a realidade específica em que a escola está inserida, para fortalecer as relações entre o sistema de ensino e a mesma.

A interferência pedagógica se dá, tendo em vista a formação de cidadãos participativos, responsáveis, comprometidos, críticos e criativos por meio da educação em um ambiente escolar que possua os atributos necessários à promoção desta construção. O PPP é uma ruptura com a verticalização das propostas educacionais. Compete às instâncias superiores o apoio financeiro, recursos humanos e o apoio às inovações nas escolas e no processo de construção deste instrumento de emancipação escolar.

Construir um PPP requer grande reflexão e inúmeras ações que vinculam teoria e prática e nem sempre tem conseguido superar a dicotomia entre as dimensões política e pedagógica. Transformação significa mudança na base político-econômica, que sustenta uma estrutura social. A educação atua no nível da formação de consciências e não diretamente na base estrutural da sociedade.

Assim, o PPP só se concretiza na sala de aula. Não basta possuir um projeto é necessário que ele esteja latente todo o tempo na sala de aula. Funciona do professor para o aluno. No entanto, sua construção deve contemplar as necessidades e visões de todos os agentes da escola: professores, direção, funcionários e alunos. 
Mário Osório Marques (2004) afirma que o projeto político pedagógico não é algo que surge do nada. A aprendizagem escolar é aquela formalmente intencionada e sistemática em tempo e lugar próprios e com recursos adequados. Para que haja democratização da aprendizagem e universalização dos direitos educacionais, é fundamental "tanto vontade política quanto uma sociedade civil fortalecida, com espaço e voz para poder participar efetivamente do sistema educacional" (SACAVINO, 2007). Isso requer uma transformação, definição e implementação das políticas educacionais, além da distribuição eqüitativa dos recursos e do acesso ao direito à educação.

Demo (1995) ressalta o baixo índice de aprendizagem nas escolas públicas decorrente do despreparo dos professores. A situação da escola pública se dá não só pelos índices de pobreza, mas pela má qualidade dos professores que, para melhorarem suas aulas precisam, antes de tudo, "aprender a aprender". Cuidar do professor passa pela melhoria da sua formação e investimento em sua organização sindical para promover sua cidadania e conscientização política.

O Estado brasileiro possui como princípio a afirmação dos direitos humanos como universais, indivisíveis e interdependentes e, para sua efetivação, todas as políticas públicas devem considerá-los na perspectiva da construção de uma sociedade, baseada na promoção da igualdade de oportunidades e da eqüidade, no respeito à diversidade, na consolidação de uma cultura democrática e na justiça social.

O governo brasileiro possui, nessa direção, o compromisso maior de promover educação de qualidade para todos, erradicando o analfabetismo, oferecendo melhoria da qualidade a todos os níveis das diversas modalidades de ensino.

A efetivação dos compromissos contidos no PNEDH somente será possível com ampla união de esforços em prol da realização dessa política, que deve configurar-se como política de Estado. 
Educar em direitos humanos é um desafio central da humanidade, que tem maior importância na América Latina caracterizada, tanto por déficits históricos nas violações dos direitos humanos quanto por graves e sistemáticas violações dos direitos básicos de segurança, sobrevivência, identidade cultural, e bem-estar mínimo de grandes contingentes populacionais.

A difusão da cultura dos direitos humanos no país prevê a disseminação de valores solidários, de justiça social e de cooperação, fortalecendo a sociedade civil através da identificação de suas necessidades, transformando-as em conquistas, ao passo que o governo brasileiro venha a valorizá-las tornando-as políticas públicas universais.

A educação precisa ser compreendida como um direito em si mesmo e como principal meio de acesso aos demais direitos. A cidadania plena só será efetivada quando a educação ocupar um lócus de importância para o pleno desenvolvimento humano e suas potencialidades, por meio da construção do conhecimento, desenvolvimento dos valores, atitudes e comportamentos, da justiça social, defesa do meio-ambiente e respeito aos socialmente excluídos.

"A violação dos direitos humanos produz vítimas. Vítimas são aquelas
pessoas humanas que sofrem qualquer tipo de apequenamento ou de negação
de seu ser humano, de seu ser ético. Em termos ético-filosóficos, vítima é
aquele ser que está numa situação na qual é inviabilizada a possibilidade de
produção e reprodução de sua vida material, de sua corporeidade, de sua
identidade cultural e social, de sua participação política e de sua expressão
como pessoa, enfim, da vivência de seu ser sujeito de direitos."
(CARBONARI, 2007, p. 170)

Educar em direitos humanos, por assim dizer, significa gerar possibilidades emancipatórias nos educandos. Reconhecê-los como sujeitos de direito é o primeiro passo para a efetivação e da cidadania plena. Mais do que garantir direitos, a escola possui o papel de favorecer a libertação dos alunos da sua situação de vítima. Tal libertação se dá ao passo 
que a escola não só instrui por meio dos conhecimentos curriculares, mas, antes disso, se importa com a formação de valores visando à cidadania.

Reconhecer a dignidade do outro é essencial para que as práticas escolares não sejam direcionadas pelo paternalismo, reproduzindo a vitimização daquele que deveria ser, de fato, sujeito de direitos.

Mais do que ensinar: fazer pensar, fazer refletir a respeito de sua realidade é a essência do ato de educar. Educar implica em libertar (dar ao outro a possibilidade de libertar-se), em contribuir para a formação de sujeitos livres e autônomos que tenham respeitadas sua autonomia e liberdade. "A construção dos sujeitos se dá na tensão entre liberdade e igualdade" (CARBONARI, 2007). A liberdade explora as diversas opções, dá espaço a escolhas, conforme as diferenças. A igualdade garante o acesso de todos a um mínimo de possibilidades com justiça, não obstante às diferenças.

A proteção dos direitos vai além da mera defesa dos mesmos. Alcança a construção de direitos e é isso que a escola deve primar: a formação de cidadãos pensantes, críticos, capazes não só de buscar a garantia de seus direitos, mas também e, principalmente, de serem reconhecidos como capazes de contribuir para a construção e reconstrução dos direitos. "A garantia dos direitos é processo de realização plural e multidimensional; muito mais que satisfação das carências. As carências e necessidades básicas precisam ser satisfeitas, mas também sempre em perspectiva universal e aberta, como desenvolvimento de potencialidades.” (CARBONARI, 2007).

Práticas fragmentadas que valorizam o preenchimento de quadros, questionários de avaliação e o cumprimento de metas, dificultam ou não estimulam uma reflexão das práticas pedagógicas visto que estão baseadas no reducionismo da escola. Não preparam o aluno para o exercício da cidadania e muito menos o qualificam para o mercado de trabalho. Tais práticas sufocam o potencial humano dos alunos e sua capacidade crítica. 
A unidade entre teoria, prática, valores, ações conscientes e organizadas, participação e reflexão coletiva, além de uma articulação da escola com a comunidade e a família são imprescindíveis à promoção da emancipação e da autonomia dos sujeitos.

A verdadeira educação deve cumprir, com excelência, a tarefa de construir sujeitos pluridimensionais, humanizados, com condições mínimas de lutar pela garantia da sua dignidade humana, capazes de fazer uma leitura saudável da realidade em que estão inseridos para que passem a serem cooperativos, responsáveis e comprometidos com a efetivação e a garantia dos direitos humanos.

Por fim:

"Propor-se a pensar e a fazer educação em direitos humanos é muito mais do que dar vazão para uma coleção de boas intenções e a mobilização de boas vontades - por mais que sejam necessárias. Exige encetar a novidade como um compromisso ético, social e político capaz de se traduzir em práticas alternativas e transformadoras que se consolidem tanto em normas exteriores e institucionais, quanto em convencimento e vivência." (CARBONARI, 2007, p.184).

\section{6- METODOLOGIA}

Esta pesquisa teve por objetivo conhecer, a partir de uma perspectiva dialética estrutural-histórica e por meio de um estudo de caso, a presença da educação em direitos humanos, no projeto político-pedagógico do Centro de Ensino Fundamental 01 de Sobradinho - CEF 01 .

As diversas categorias capazes de captar os conflitos e tensões existentes nessa instituição social serão analisadas nesta perspectiva, porque a realidade encontra-se em constante transformação. A dialética considera a realidade contraditória, porque sua dinâmica é de igual forma, contraditória. Assim a escola precisa ser vista em sua totalidade, a partir de sua historicidade em seu contexto social, econômico, político e cultural, levando-se em conta 
que esta instituição é formada por sujeitos autônomos que traçam suas trajetórias dentro deste ambiente.

Para tomar parte desta realidade, fez-se apropriada a pesquisa qualitativa, pois esta responde a questões bastante particulares, tais como significados, motivos, crença, valores, categorias difíceis de serem mensuradas ou quantificadas, porém essenciais à apreensão da realidade em que o significado se configura como conceito principal da investigação.

"A expressão pesquisa qualitativa assume diferentes significados no
campo das ciências sociais. Compreende um conjunto de diferentes
técnicas interpretativas, que visam a descrever e a decodificar os
componentes de um sistema complexo de significados. Tem por
objetivo traduzir e expressar o sentido dos fenômenos do mundo
social; trata-se de reduzir a distância entre o indicador e o indicado,
entre a teoria e os dados, entre o contexto e a ação" (MAANEN, 1979,
p. 520).

Como são diversas as formas de avançar no conhecimento de um fenômeno, diferentes maneiras de conceber e lidar com o mundo geram formas distintas de perceber e interpretar os significados e sentidos do objeto pesquisado, que não se opõem nem se contradizem. O contexto e a integração com o objeto de estudo implicam uma melhor compreensão do fenômeno estudado, permitindo o uso de comparações, descrições e interpretações.

"Diferentemente da arte e da poesia, que se concebem na inspiração, a pesquisa é um labor artesanal, que se não prescinde da criatividade, realiza-se fundamentalmente por uma linguagem fundada em conceitos, proposições, métodos e técnicas, linguagem esta que se constrói com ritmo próprio e particular" (DESLANDES, 1994, P.25). A abordagem qualitativa não pode pretender o alcance da realidade como um todo; deve ter como preocupação primeira a compreensão da lógica que permeia a prática no contexto da realidade social. 
Como o foco da pesquisa encontra-se em fenômenos contemporâneos, dentro do contexto de vida real, faz-se adequado um estudo de caso, pois este possui a possibilidade de aprofundamento, visto que os recursos encontram-se concentrados no objeto de estudo e o objetivo central é compreender as relações sociais: “A função da pesquisa não é a de simplesmente descrever o observado, mas sim compreendê-lo" (LAVILLE e DIONNE, 1999).

Como instrumentos de coleta de dados foram utilizados a observação participante e entrevistas contendo perguntas abertas e fechadas que foram aplicadas com 8 professores, 1 diretor e 1 coordenador pedagógico.

A observação participante é bastante indicada para que se possa conhecer melhor a realidade escolar, em virtude de permitir a familiarização com o local de pesquisa, garantindo uma compreensão mais profunda das vivências cotidianas presentes no comportamento dos professores, alunos, gestores e funcionários. "Consiste na participação real do pesquisador com a comunidade ou grupo. Ele se incorpora ao grupo, confunde-se com ele" (MARCONI E LAKATOS, 1994).

A entrevista proporciona uma interação social entre pesquisador e entrevistado e garante uma maior qualidade dos dados levantados. O roteiro de entrevista foi composto por perguntas sobre: finalidade da escola, estrutura organizacional, currículo, controle social, tempo escolar, processo de decisão, relações de trabalho e avaliação. Foi construído de forma semi-estruturada, com perguntas previamente formuladas, porém com certa abertura para uma abordagem livre do tema proposto, incluindo a possibilidade de formular novas questões no momento da entrevista.

Assim, a pesquisa foi focalizada no Centro de Ensino Fundamental 01 de Sobradinho - DF. Foram entrevistados 8 (oito) professores, 1 (uma) diretora e 1 (um) 
coordenador pedagógico. A aplicação das entrevistas foi realizada entre os meses de abril e maio de 2008, tendo ocorrido boa receptividade da pesquisadora por parte dos entrevistados.

Os dados coletados são apresentados sob forma de gráficos com percentuais referentes às freqüências obtidas para cada categoria em análise, de modo a dar visibilidade aos mesmos.

\section{7- ESTUDO DE CASO: Centro de Ensino Fundamental 01 de Sobradinho DF - CEF 01}

O Centro de Ensino Fundamental 01 de Sobradinho - CEF 01- foi construído em 1972 e inaugurado em 1973. Fisicamente, conta com uma boa estrutura: possui 11 salas de aula, 01 sala especial, 01 biblioteca, 01 secretaria, 01 sala para a direção, 01 sala onde funciona o áudio e o administrativo, 01sala de professores com copa, 01 banheiro para portadores de necessidades especiais, 01 depósito de educação física, 02 banheiros para educação física, 01 depósito de material, 01 laboratório de informática com 20 computadores, 01 sala de coordenação, 01 cantina conjugada com o depósito de merenda, 01 pátio coberto, 02 banheiros para alunos, 01 sala de vídeo/múltiplas funções, 01 depósito de material de limpeza, 02 banheiros para servidores, 01 sala para servidores, 01 guarita e 01 quadra esportiva.

Apesar do tempo de construção, a escola encontra-se em bom estado de conservação e limpeza. Possui jardins, mantidos por membros da direção e alguns professores. O espaço físico é bem aproveitado e, na medida do possível, pequenas reformas são feitas com o apoio da comunidade, de alguns pais e do empresariado local. Os quadros das salas de aula ainda são de giz. O sistema de ventilação é precário, visto que parte dos ventiladores datam da inauguração da escola e não funcionam mais, além do telhado ser de amianto, contribuindo para o aquecimento das salas de aula. A quadra de esportes encontra-se 
em situação bastante precária: possui muitos buracos e não é coberta, necessitando de reforma com urgência.

Geograficamente, a escola encontra-se entre duas comunidades com perfis sócio-econômicos distintos: a quadra 02 de Sobradinho, população de classe média, e o DNOCS, comunidade localizada à direita da BR 020, no sentido Brasília-Sobradinho, ao lado do Setor de Expansão Econômica de Sobradinho. Este é constituído por uma população de baixa renda, não possui infra-estrutura básica, é conhecido como uma "favela" e o GDF está em vias de regularizar o loteamento e urbanizá-lo.

Atualmente, a escola conta somente com verbas institucionais do governo do Distrito Federal - GDF. As tentativas de recolhimento de taxas de Associação de Pais e Mestres - APM foram bastante frustradas em função de boa parte dos alunos pertencerem a uma comunidade carente, e suas famílias, não muito raro, possuírem como única fonte de renda os projetos sociais governamentais.

O CEF 01 atende 674 alunos, distribuídos em 19 turmas, em 02 turnos: matutino e vespertino. As turmas atendem, em média, a 35 alunos, sendo distribuídas da seguinte maneira: 03 turmas de $4^{\mathrm{a}}$ série; 05 de $5^{\mathrm{a}} ; 03$ de $6^{\mathrm{a}} ; 03$ de $7^{\mathrm{a}} ; 03$ de $8^{\mathrm{a}}$, além de 01 de aceleração da $4^{\mathrm{a}}$ e 01 de aceleração da $8^{\mathrm{a}}$.

Para atender às necessidades dos alunos e viabilizar o ensino, a escola conta, atualmente, com 32 professores, 01 secretário administrativo, 01 diretora, 01 vice-diretor, 02 coordenadores pedagógicos, 08 servidores de conservação e limpeza, 04 merendeiras, 03 vigias e 02 porteiros. A biblioteca é assistida por uma servidora readaptada.

O projeto político-pedagógico de 2007-2008 estabelece como missão da escola "implementar novas iniciativas que conduzam à elevação no nível de aprendizagem dos alunos e uma integração disciplinar mais efetiva, procurando assim preparar o educando para viver plenamente a cidadania, cumprindo seus deveres e usufruindo seus diretos" 
(grifo nosso). Como metas, dentre outras, cabe ressaltar: capacitar lideranças entre os adolescentes; dar condições para a atuação do Conselho Escolar e incentivar a participação dos pais na vida escolar dos filhos.

As demais metas adotadas no projeto político-pedagógico da escola são: 1) a Lei de Diretrizes e Bases da Educação Nacional (Lei 93494/96), onde é ressaltado o dever do poder público para com a educação em geral e, em particular, para com o ensino fundamental, assegurando a todos "a formação comum indispensável para o exercício da cidadania e fornece meios para progredir no trabalho e em estudos posteriores"; 2) Parâmetros Curriculares Nacionais como referenciais de qualidade para a educação no ensino fundamental em todo o país, delimitado com a função de "garantir o respeito às diversidades culturais, regionais, étnicas, religiosas e políticas que atravessam uma sociedade múltipla e estratificada".

Por último, ressalta no Currículo da Educação Básica das Escolas Públicas do Distrito Federal como um de seus princípios: "valores e atitudes - permeiam o currículo em sua totalidade (...) o corpo docente do CEF 01 dedica-se à discussão e viabilização de estratégias que forneçam a formação de valores e atitudes em seus alunos”. O CEF 01 em seu PPP adota como filosofia Os Quatro Pilares da Educação, relatório de Jacques Delors, publicado em 1996 pela Organização das Nações Unidas para a Educação, a Ciência e a Cultura (UNESCO), que ressalta a importância de: a) aprender a aprender; b) aprender a fazer; c) aprender a conviver; e) aprender a ser. Com esses princípios educativos da escola do século XXI, o CEF 01 articula seu projeto político-pedagógico a partir de uma compreensão humanista e capaz de preparar os educandos para lidar com os desafios do presente.

O PPP da escola propõe uma série de projetos a serem desenvolvidos pelos professores de forma inter e transdisciplinar. Dentre eles, vale ressaltar alguns que possuem de maneira mais explícita, ações ou ideologias direta ou indiretamente voltadas para valores, 
formação de consciência crítica nos alunos e promoção da inclusão social $\left(3^{\circ}\right.$ projeto citado abaixo).

1. Projeto Sala de Leitura: possui como objetivo geral "proporcionar aos alunos noções claras de análise de valores, reflexão sobre temas surgidos, ampliação de sua competência discursiva para atuar nos diversos contextos sociais, favorecendo condições básicas para tomada de decisões responsáveis e estimular o gosto pela leitura." Vale ressaltar que este projeto possui, entre suas metas, a adoção de temas transversais, principalmente, valores e atitudes. As ações planejadas prevêem a abordagem de problemas sociais tais como: menor abandonado, desemprego, analfabetismo, preconceitos, desigualdade social, problemas de migração, problemas ambientais, etc. Um dos focos deste projeto é, por meio destas ações, "proporcionar um ambiente de estímulo à produção de textos, preparando, gradativamente para a formação do indivíduo capaz de "pensar" e "fazer", ser crítico e buscar soluções".

2. Projeto Valores Humanos: "implantar a prática de valores como a Amizade, o Respeito, a Justiça e a Solidariedade para melhorar o convívio, o cooperativismo e o desenvolvimento de todos, realizando, com responsabilidade, atividades em grupos, assumindo direitos e deveres que thes correspondem." Especificamente, possui por objetivos desenvolver o respeito mútuo entre os alunos; reconhecer ações positivas para a formação de uma sociedade mais justa; facilitar o trabalho em grupo; possibilitar o contato com histórias de vida em que os valores foram essenciais; solidarizar-se ante os problemas e 
necessidades de seus companheiros, contribuindo para a superação. Vale ressaltar que, neste projeto, os alunos desenvolverão, dentre outras atividades, "ações solidárias, mostrando responsabilidade e engajamento no contexto social".

3. Projetos Individuais e Paralelos - Noções básicas da língua de sinais para a comunicação diária: possui o objetivo de "promover a comunicação básica entre ouvintes e não ouvintes".

O PPP é construído coletivamente e seu resultado expressa pensamentos, valores e atitudes relevantes. Os profissionais envolvidos nesta construção, bem como na implementação dos projetos, demonstram estarem comprometidos com um ensino de qualidade em um ambiente propício à construção do conhecimento e à formação da cidadania.

Com base no PPP, na observação participante e nas entrevistas, foi possível perceber todo o corpo docente, direção e funcionários, comprometidos com a construção de uma estrutura e um compromisso comum que favorece a relação educador/educando, visando o sucesso do processo ensino/aprendizagem.

O projeto político-pedagógico se expressa nas práticas e atitudes daqueles que contribuem para sua construção. A discussão sobre interdisciplinaridade, planejamento participativo e a própria construção coletiva do PPP, demonstra coerência nas práticas escolares e nas relações pedagógicas, bem como entre a reflexão e a ação dos indivíduos.

\section{1- Perfil sócio-econômico dos professores do CEF 01}

Nesta parte referente ao perfil sócio-econômico dos professores, serão tratadas as categorias tais como sexo, idade, estado civil, cor/raça, religião, escolaridade, renda familiar, local de moradia e tempo de serviço (como professor na SEE-DF e na escola). 


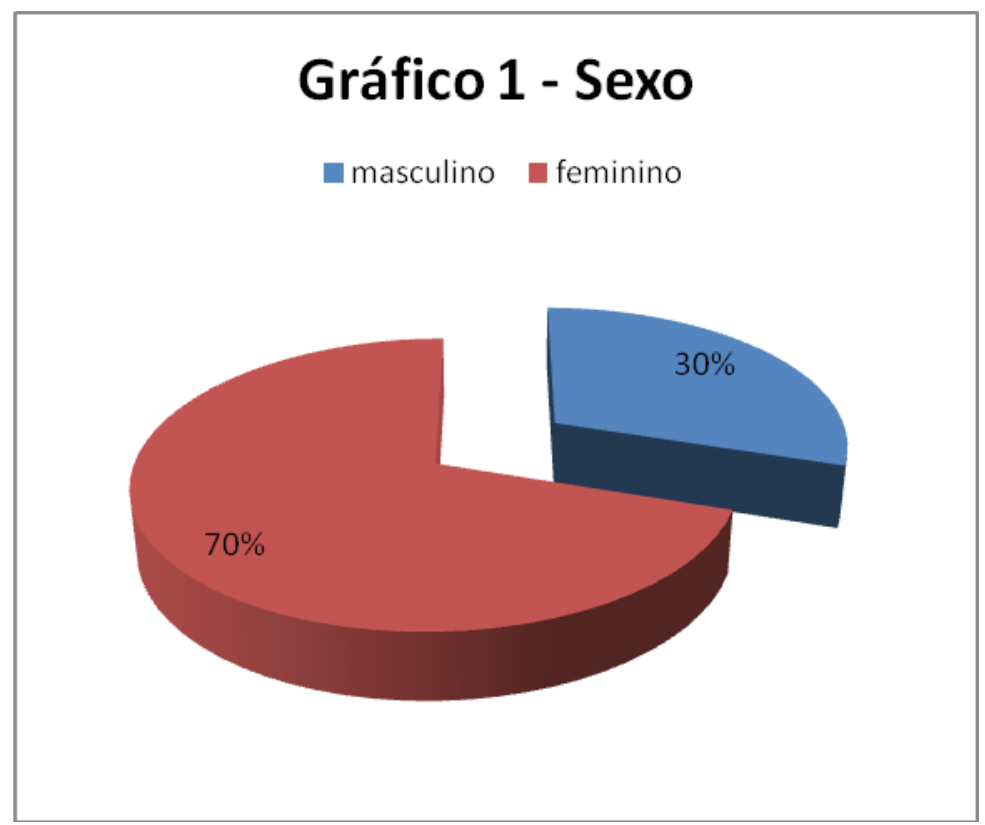

A equipe de professores entrevistados é composta da seguinte forma: $70 \%$ são mulheres e 30\% homens, ou seja, é predominantemente feminina. Esta característica é predominante na categoria docente da educação.

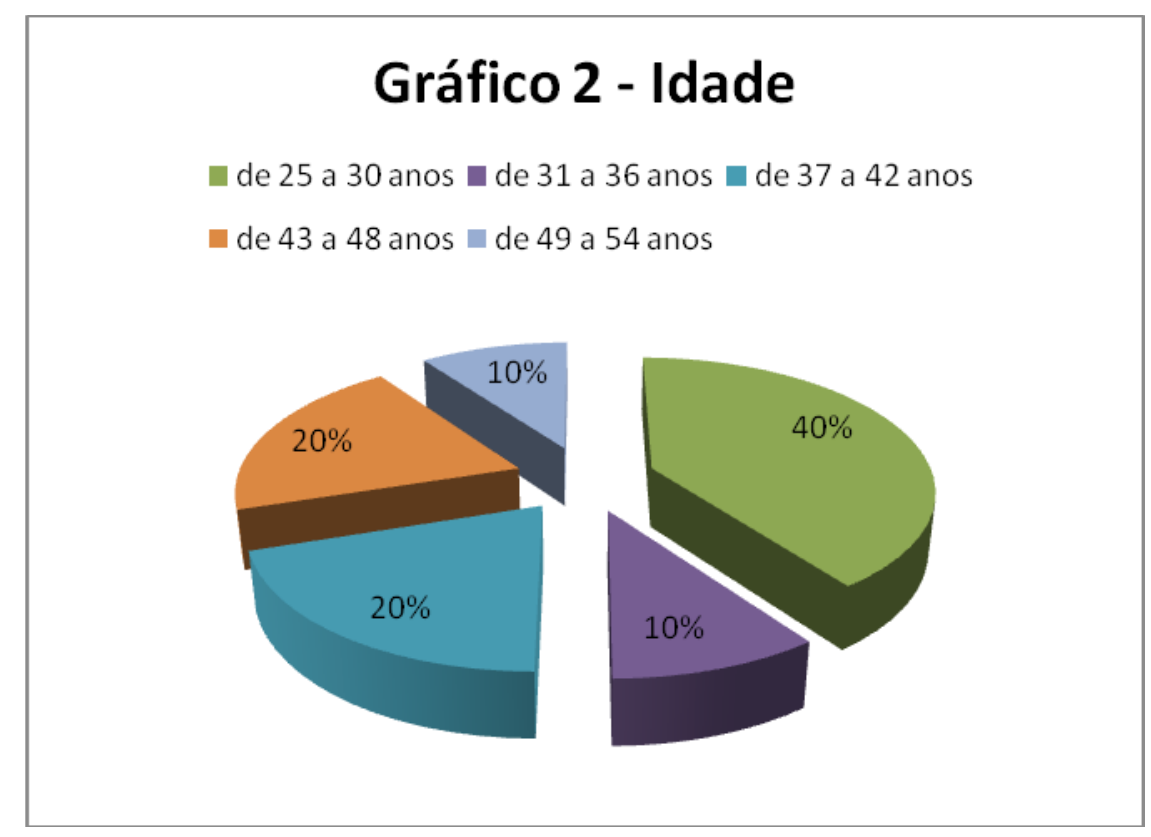

Com relação à idade, $40 \%$ dos professores são bastante jovens, entre 25 e 30 anos, $20 \%$ possui idade entre 43 e 48 anos, $20 \%$, entre 49 e 54, 10\%, entre 37 e 42 e outros $10 \%$ entre 31 e 36 anos. Este dado é interessante, pois mostra que a escola possui professores 
de diversas gerações, favorecendo um convívio mais enriquecedor para os alunos em função das histórias de vida e das experiências vividas por esses atores sociais.

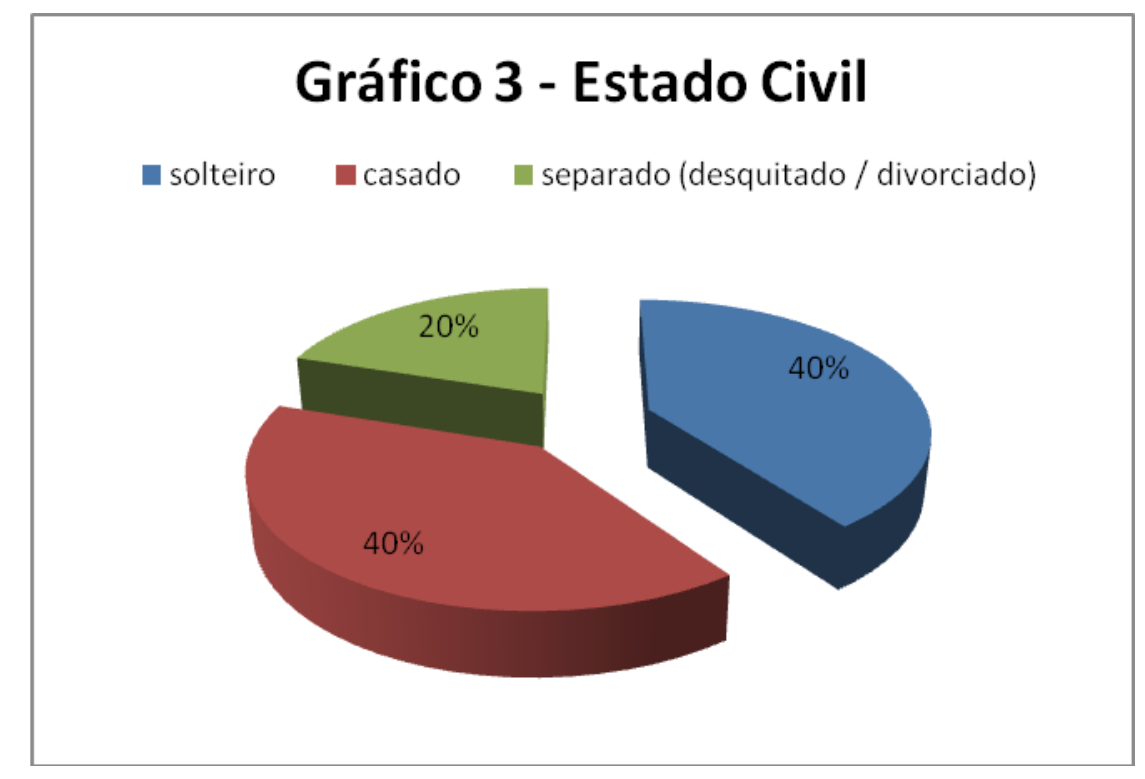

Dos entrevistados, $40 \%$ são solteiros, $40 \%$ casados e $20 \%$ separados (desquitados/divorciados). O fato de $60 \%$ possuírem ou já terem possuído experiência de vida familiar pode contribuir para o entendimento da complexidade das relações familiares vivenciadas pelos alunos, especialmente aqueles que possuem mais problemas de relacionamento com suas famílias.

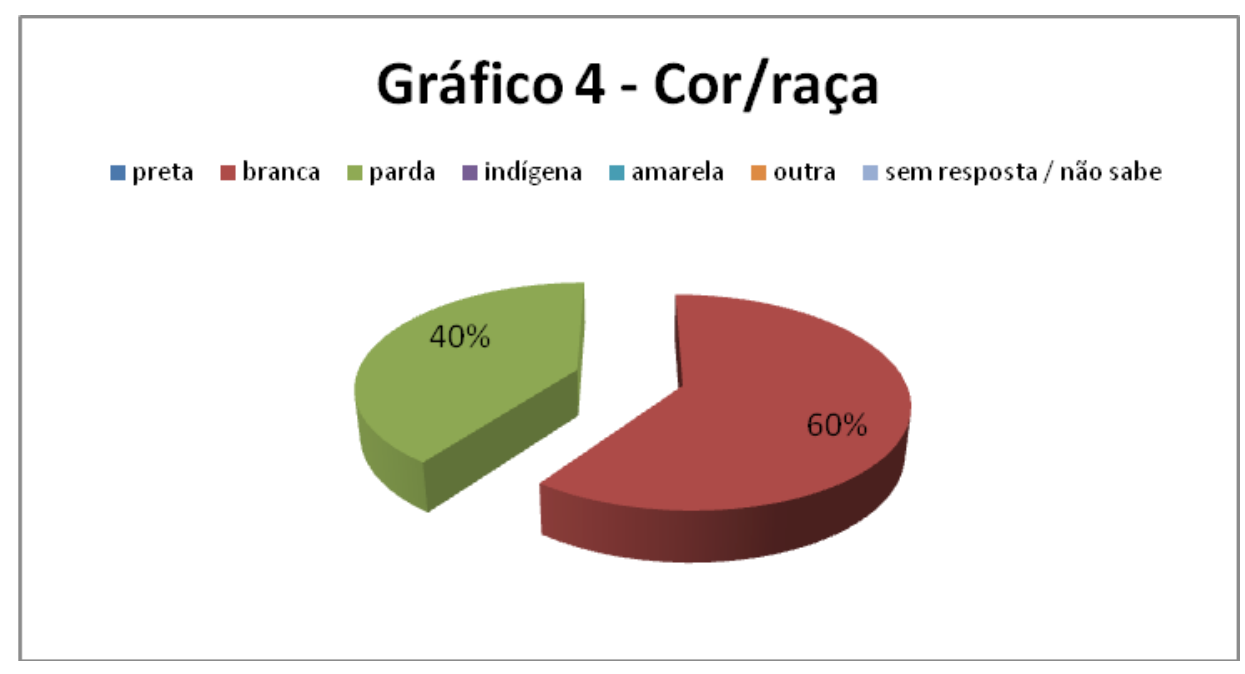

É interessante observar que, mesmo diante da diversidade cultural do nosso país, a maioria (60\%) dos entrevistados se qualificou como brancos, $40 \%$ como pardos e 
nenhum deles se enquadraram em alguma outra classificação de cor/etnia. Isto pode refletir a hierarquia social do Brasil, considerando que os indivíduos de cor branca possuem, em geral, melhores posições sociais, ocupando cargos que exigem maior formação acadêmica e trabalho intelectual.

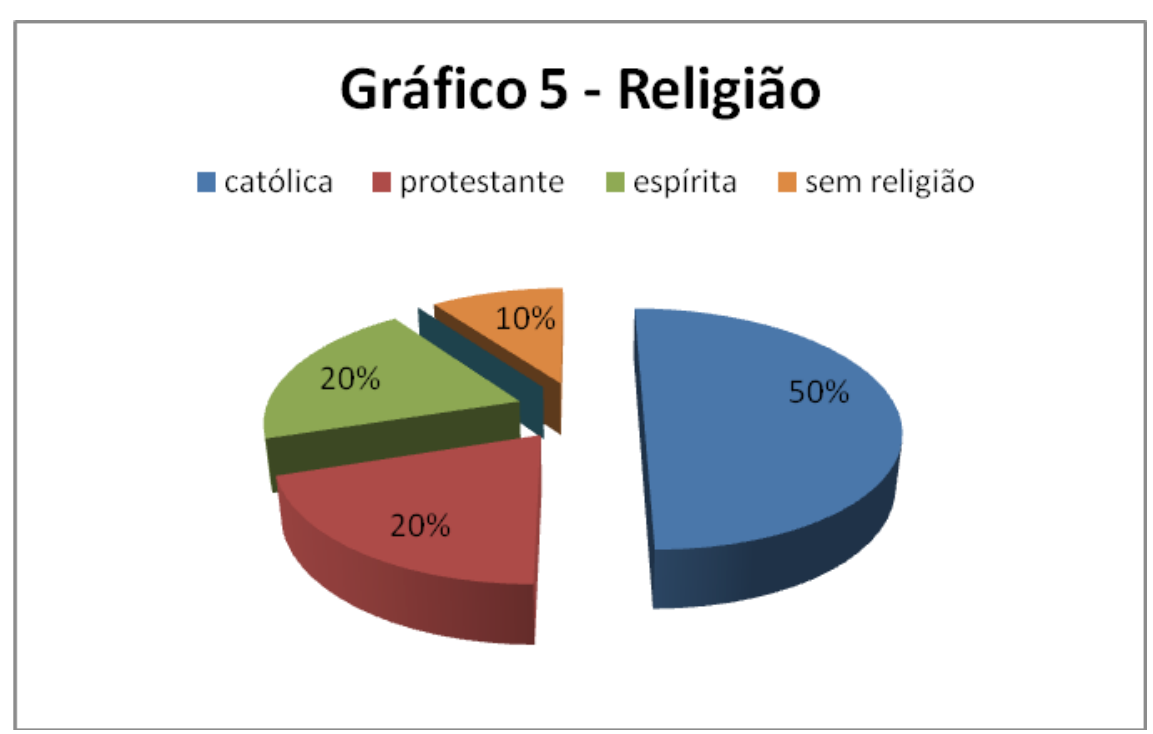

Metade, ou seja, $50 \%$ dos entrevistados são católicos, $20 \%$, espíritas, $20 \%$, protestantes e $10 \%$ se definiram sem religião. Neste caso, o catolicismo se apresenta como a religião predominante no corpo docente, sendo que apenas $10 \%$ não apresentam nenhuma filiação religiosa.

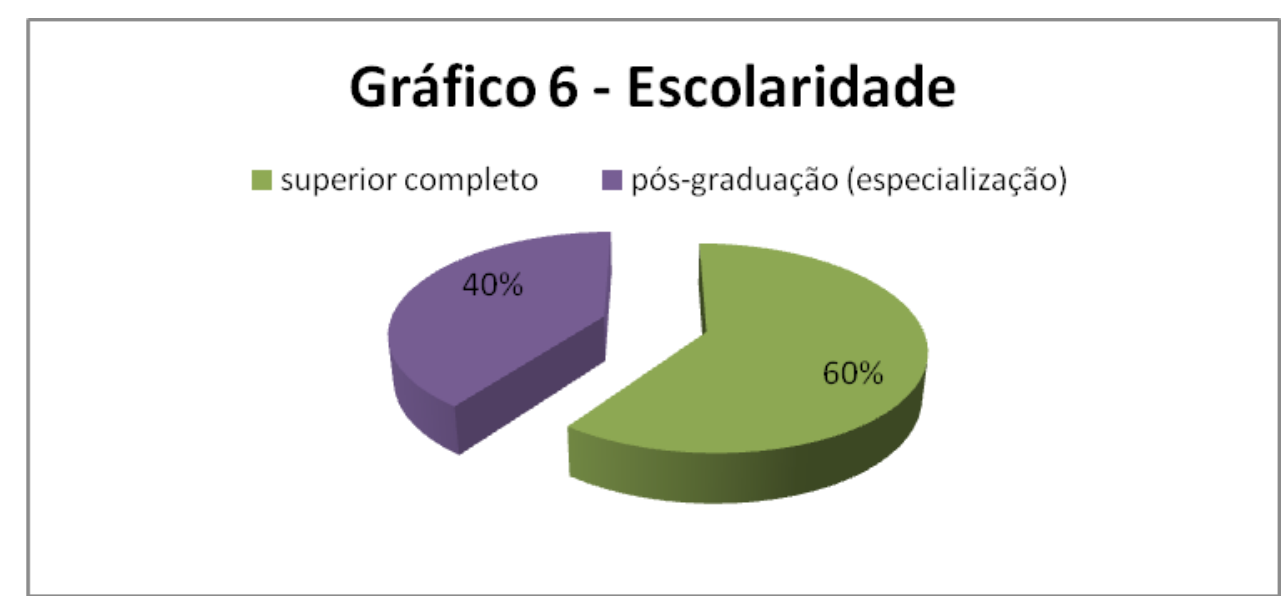

Quanto à escolaridade, $60 \%$ responderam ter nível superior e $40 \%$ declarou possuir pós-graduação a título de especialização, o que demonstra o perfil qualificado do 
corpo docente. Pode-se verificar a opção pela valorização da formação continuada, processo fundamental para agregar conhecimento e experiências, melhorando as práticas educacionais, além de favorecer a ascensão profissional e a melhoria salarial.

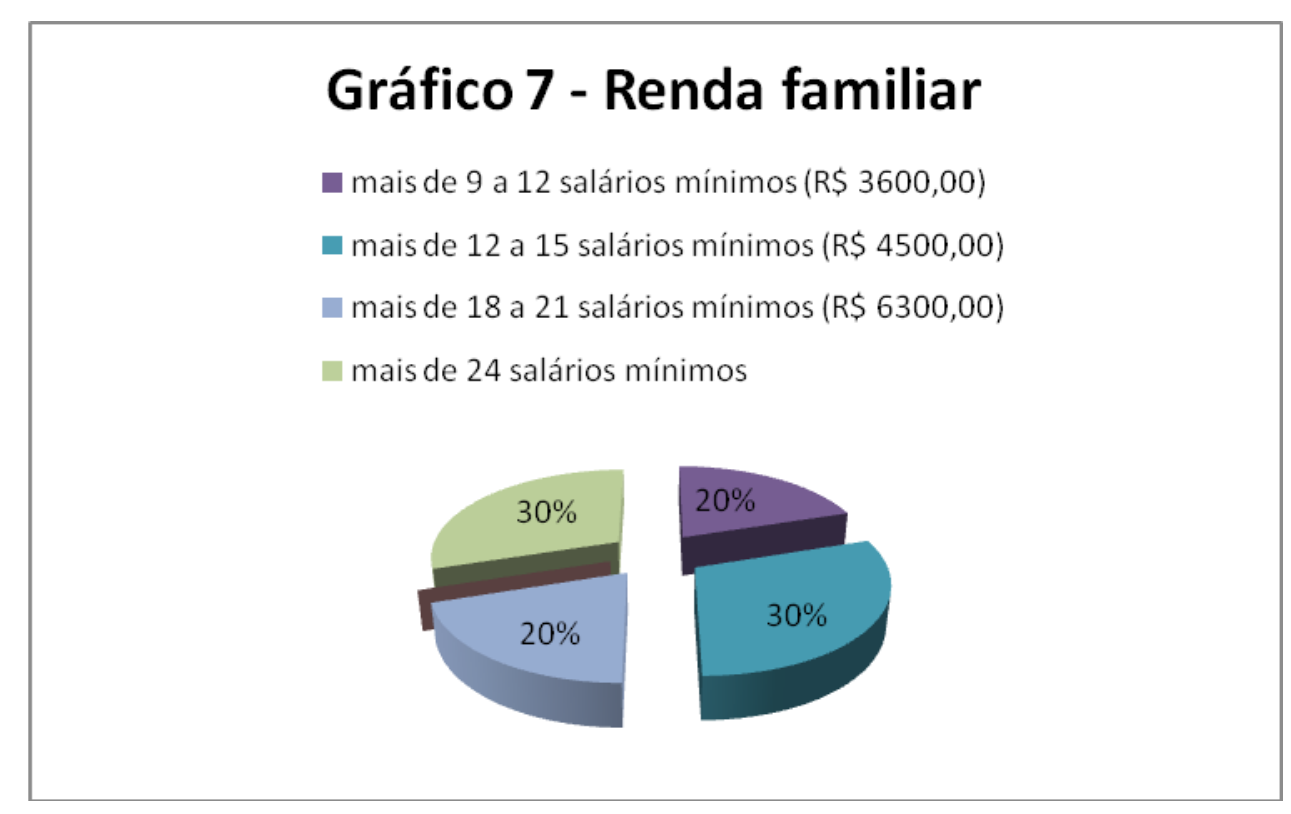

De acordo com o Gráfico 7, 30\% dos professores entrevistados possuem renda familiar superior a 24 salários mínimos, 30\% entre 12 e 15 salários, $20 \%$ entre 18 a 21 salários e outros $20 \%$ declararam estar no patamar entre 9 e 12 salários mínimos. Essas informações indicam que os professores desta escola podem ser classificados socialmente como pertencentes à classe média, possuindo condições de vida bastante privilegiadas em relação a uma considerável parte da população brasileira. 


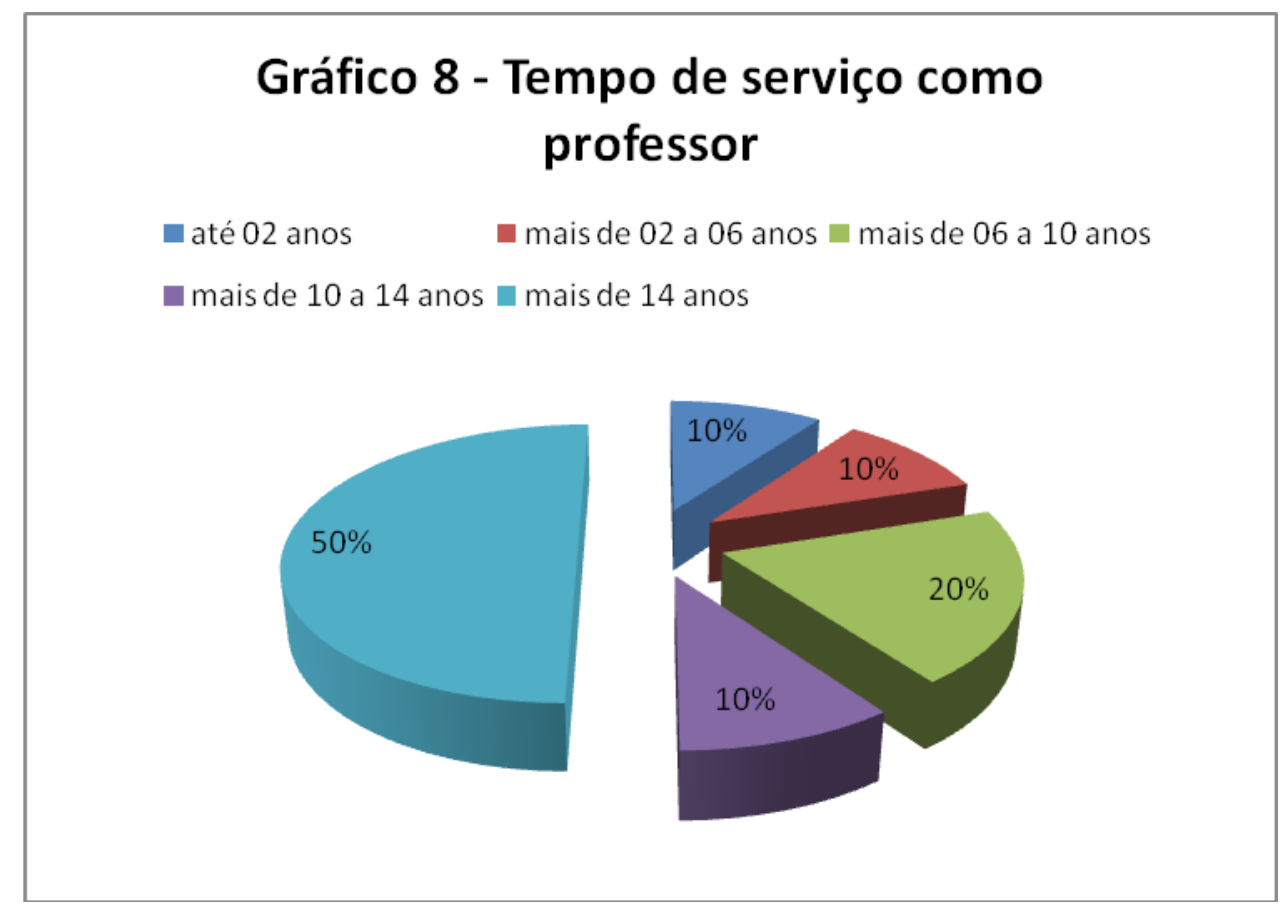

Metade dos professores (50\% dos entrevistados) tem mais de 14 anos de profissão, o que demonstra uma longa trajetória da experiência profissional presente no corpo docente escolar. $20 \%$ têm entre 6 e 10 anos, $10 \%$ entre 10 e 14 anos de profissão, outros $10 \%$ entre 2 e 6 anos e ainda $10 \%$ tem menos de 2 anos como professor. Em geral, a equipe de professores parece ser bastante experiente, o que pode facilitar a aplicação das propostas pedagógicas da escola.

\section{Gráfico 9 - Tempo de trabalho na SEE-DF}

até 02 anos mais de 02 a 06 anos mais de 06 a 10 anos

mais de 10 a 14 anos mais de 14 anos

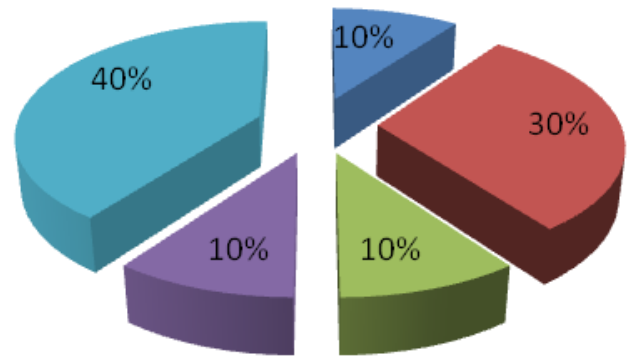


O tempo de serviço na SEE-DF aproxima-se e, algumas vezes, até se iguala ao tempo de exercício como professores: $40 \%$ dos entrevistados estão na secretaria estadual há mais de 14 anos, 30\% entre 2 e 6 anos, $10 \%$ entre 10 e 14 anos, $10 \%$ entre 6 e 10 anos e $10 \%$ possuem menos de 2 anos na SEE-DF. Neste caso, pode-se constatar que $50 \%$ dos professores entrevistados estão há mais de 10 anos na rede pública de ensino, o que pode representar uma condição favorável para uma proposta pedagógica mais comprometida com a formação cidadã dos alunos.

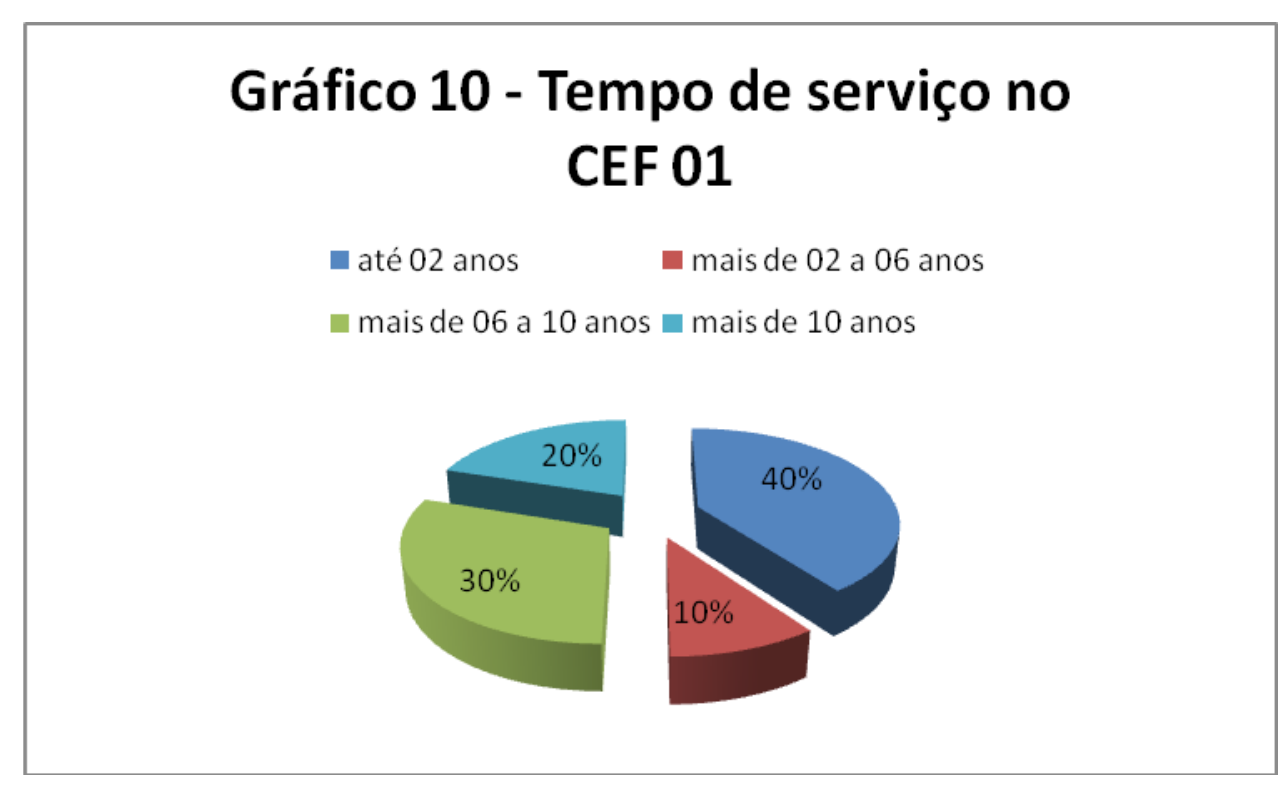

$70 \%$ dos professores entrevistados estão na escola há mais de 6 anos, demonstrando relativa estabilidade no quadro de professores, além de favorecer a implementação e continuidade dos projetos previstos no PPP da escola. Esta estabilidade é fundamental para uma boa observação crítica a respeito da realidade escolar, a construção de um projeto docente coletivo e um melhor entendimento das complexidades existentes nas relações com a comunidade em que a escola está inserida. 


\title{
Gráfico 11 - Local de moradia
}

\author{
@ Sobradinho asa Sul \# Planaltina de Goiás
}

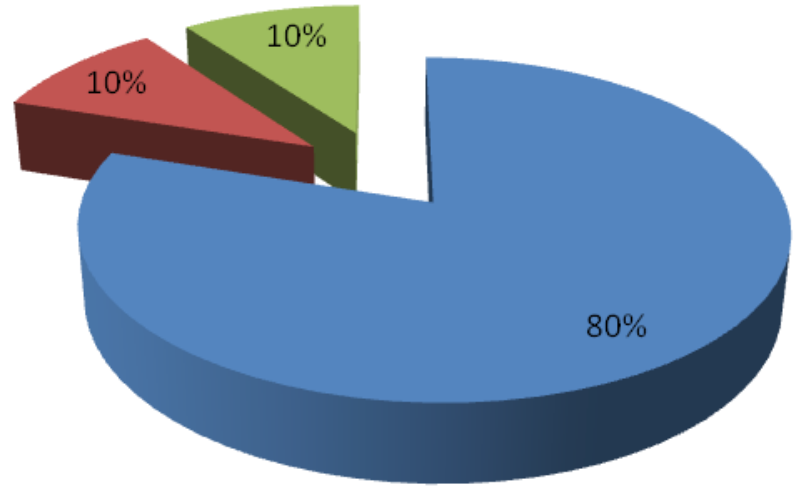

É possível observar no Gráfico 11que a grande maioria dos professores entrevistados possui fácil acesso ao local de trabalho visto que $80 \%$ deles residem em Sobradinho. Apenas dois possuem moradia fora do local de trabalho: um mora na Asa Sul e outro em Planaltina de Goiás, cidade localizada na região do Entorno do DF. Isto, sem dúvida, facilita o acesso à escola, assim como diminui a sobrecarga do deslocamento diário entre o local de moradia e de trabalho.

\section{2- Perfil político-ideológico}

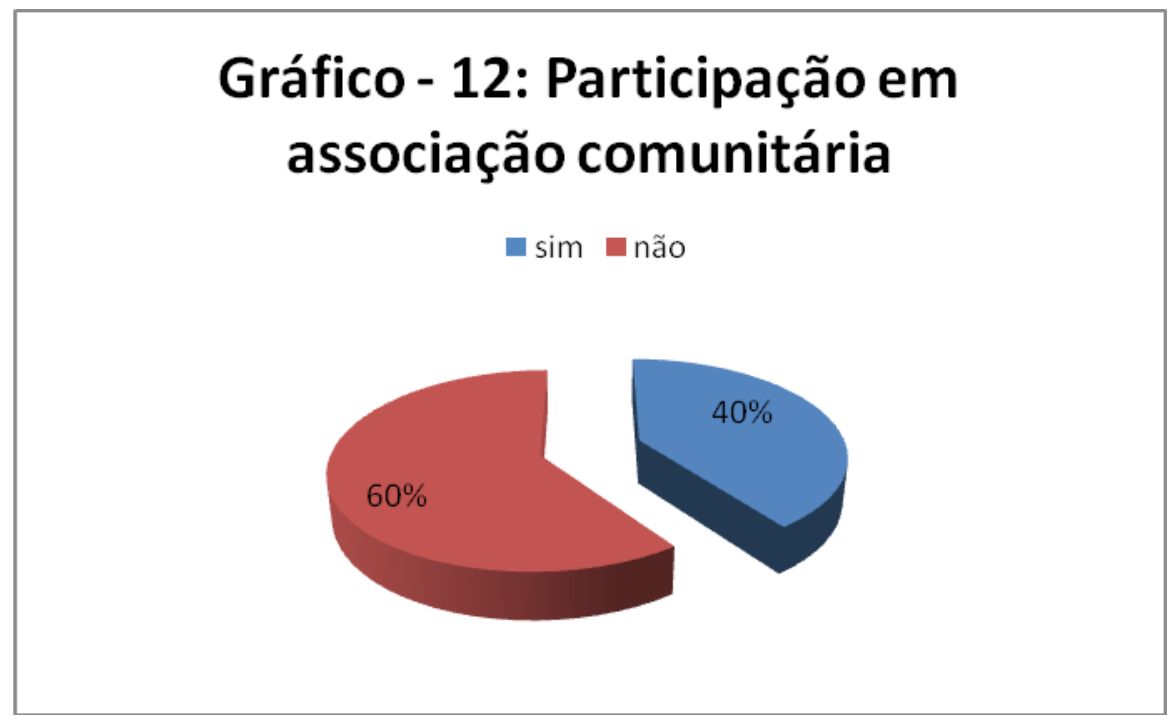


Quando indagados a respeito da participação em algum tipo de associação comunitária (associação de moradores, prefeitura comunitária, clube esportivo, etc), a maioria (60\%) afirmou nunca ter se envolvido em atividade deste tipo. Isto é bastante significativo, pois a experiência social dos docentes entrevistados parece estar restrita às relações privadas da vida familiar.

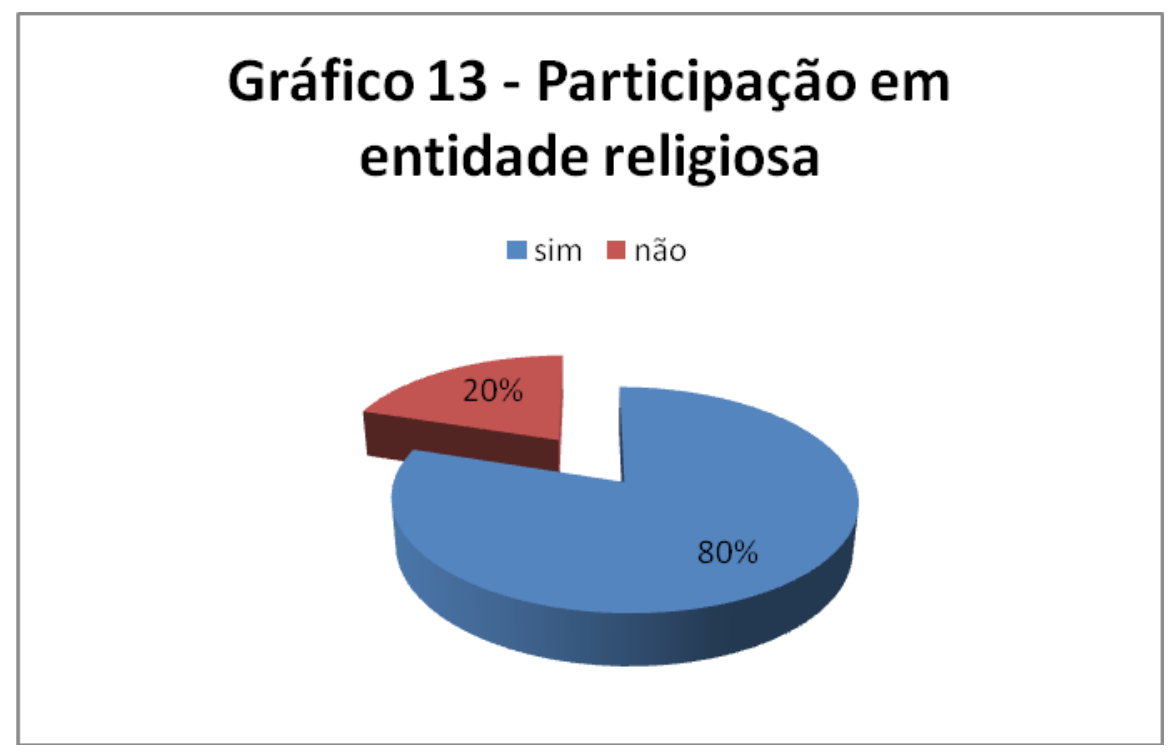

$80 \%$ dos professores participam em organismos religiosos e somente $20 \%$ dos entrevistados jamais participaram de entidade religiosa. Este dado pode estar relacionado com a predominância de mulheres no grupo dos docentes que, em geral, estão mais presentes nas práticas religiosas do que os homens.

\section{Gráfico 14 - Filiação sindical (SINPRO)}

m $\operatorname{sim}$ mão

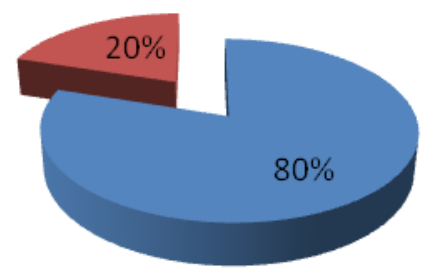


A grande maioria dos entrevistados $(80 \%)$ é filiada ao Sindicato dos Professores do Distrito Federal. Tal filiação é justificada pelo fato deles entenderem o sindicato como uma forma de organização social que tem por objetivo promover a luta da classe, representar os interesses da categoria, além de fiscalizar e combater possíveis abusos por parte dos empregadores.

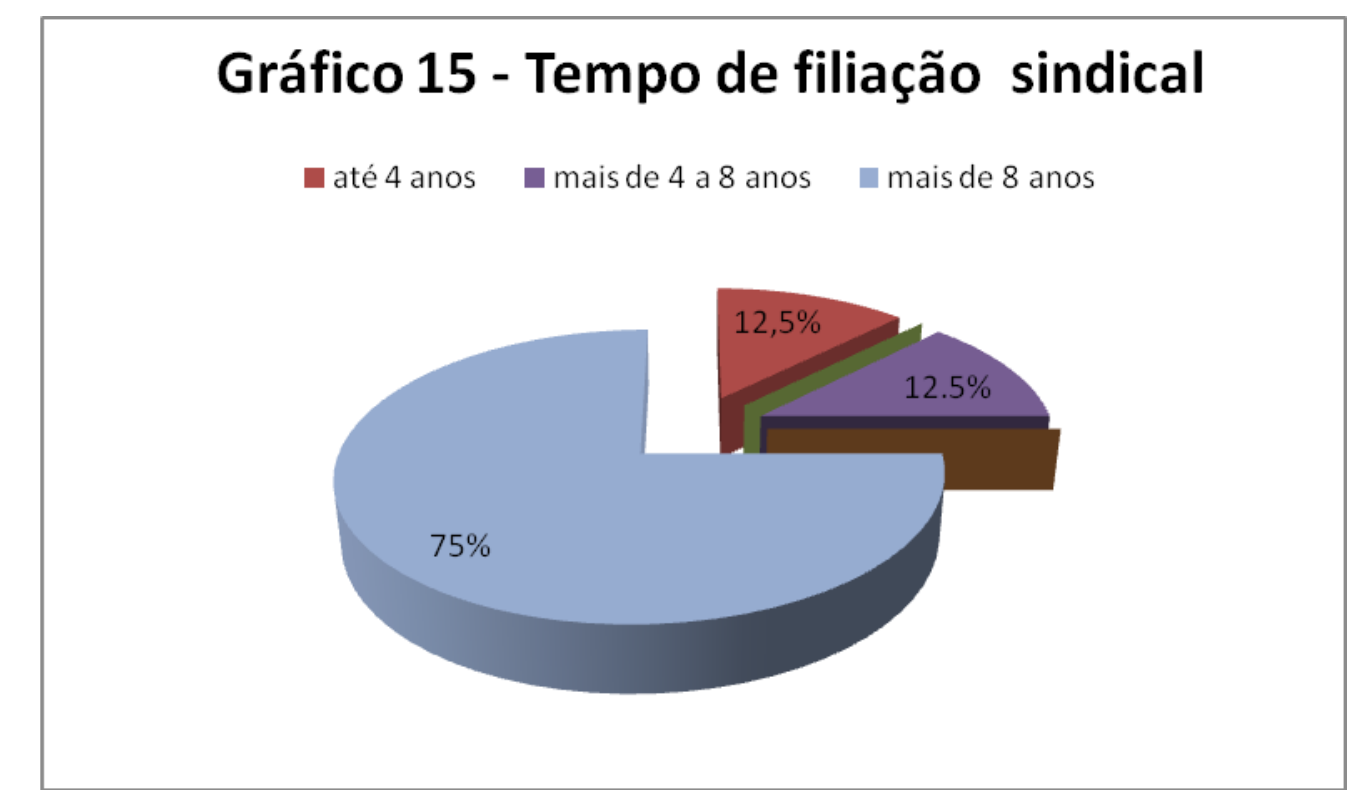

Considerando o universo de filiados composto de 8 professores, $60 \%$ possuem mais de 8 anos de filiação ao SINPRO, 10\% possui entre 4 e 8 anos e $10 \%$ possuem até 4 anos de filiação. Esta característica é interessante, pois apesar do grupo de entrevistados não ter experiências participativas junto a entidades comunitárias, eles estão vinculados ao órgão representativo da categoria. 


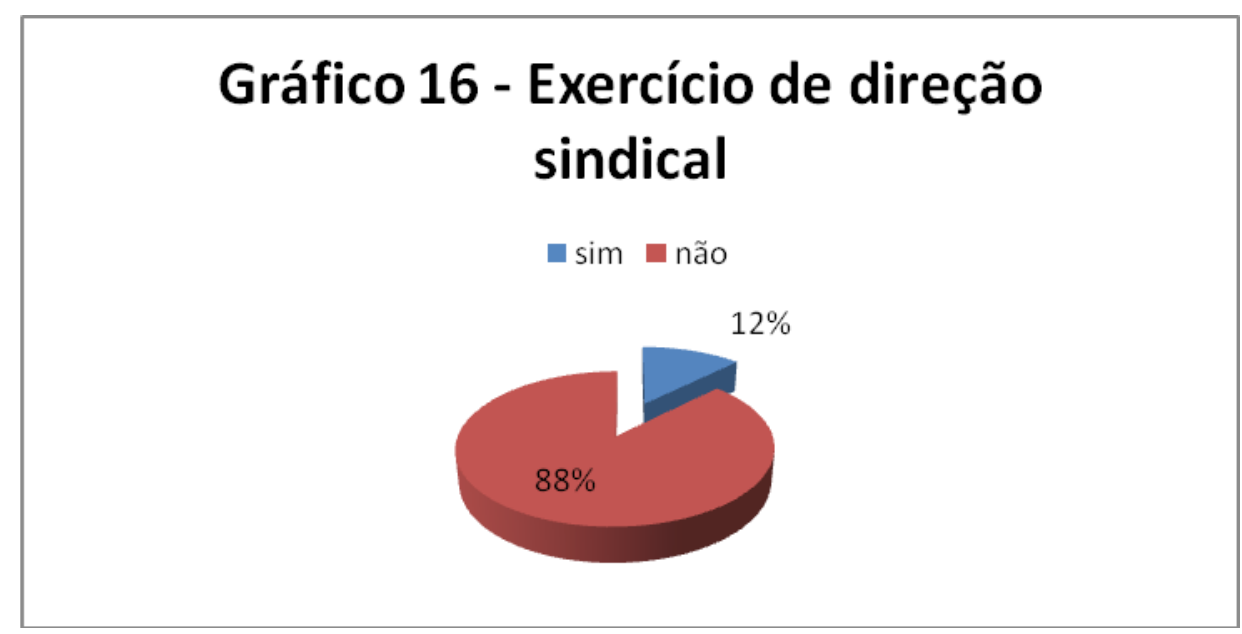

Considerando ainda o universo de entrevistados filiados ao sindicato (88\%), apenas 1 (12\%) já ocupou o cargo de delegado sindical entre 1988 e 1991. Estes dados indicam que a experiência organizativa em entidade sindical é pouco difundida entre os docentes.

Indagados a respeito das conquistas do sindicato de 1980 até os dias de hoje, eles ressaltaram com o plano de carreira, a melhoria salarial, as gratificações e a regulamentação da jornada de trabalho. Conforme pode ser observado, os professores enfatizam as reivindicações por melhores condições de trabalho.

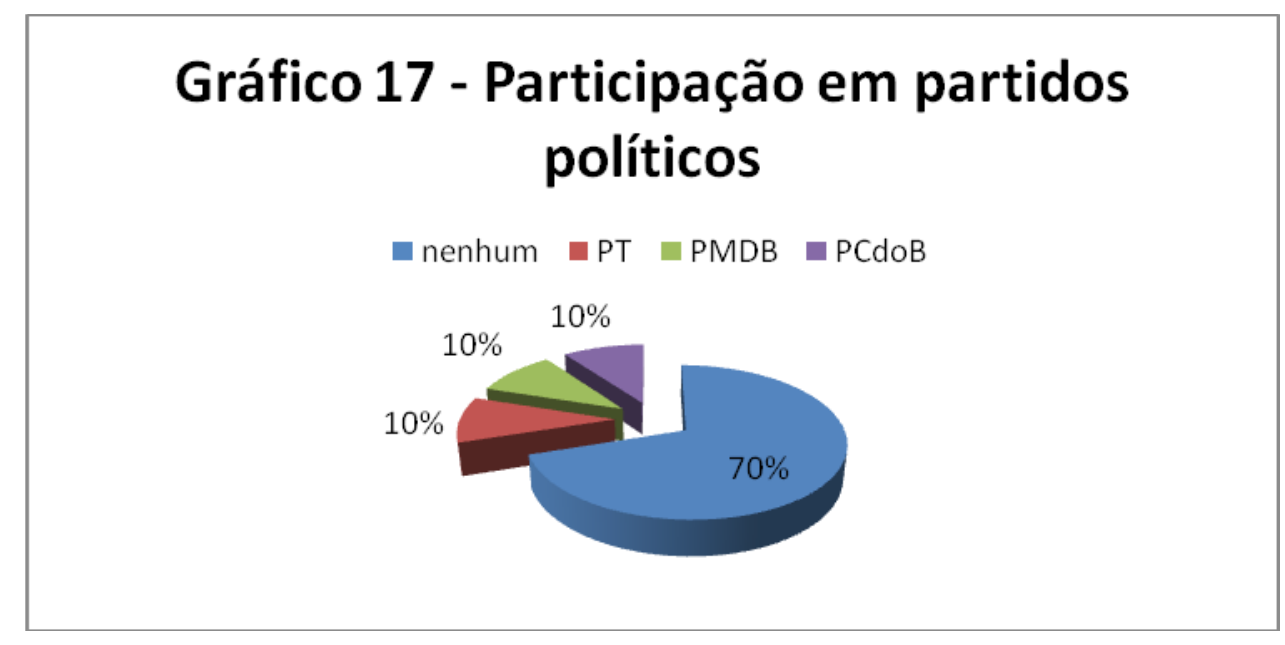

O pertencimento a partido político é pouco presente entre os entrevistados, pois somente $30 \%$ dos professores possuem alguma filiação partidária. 
Dos três filiados a partidos políticos, um pertence ao PMDB, outro ao PT e o terceiro ao PCdoB. O mais interessante é que, apesar de serem filiados, nenhum deles é militante de qualquer partido político. No discurso utilizado para justificar a ausência de militância e o distanciamento dos docentes em relação à política, ficou explícito o desgosto com a situação política atual e o desânimo frente às dificuldades políticas do país.

\section{3- Escola e comunidade}

O CEF 01 realiza pequenos trabalhos em parceria com a sociedade civil. $\mathrm{O}$ empresariado local e alguns pais auxiliam na manutenção e melhoria das instalações e na arrecadação de material para viabilizar os eventos e festas da escola. A comunidade também participa com doações de alimentos para gincanas e festas.

É interessante ressaltar o "Dia da Família", um evento que a escola faz bimestralmente, visando estimular a participação da família na educação de seus fillhos. Neste dia é apresentado o resultado das notas, além dos trabalhos artísticos e literários dos docentes. Apresentações de dança, música, arte e teatro mobilizam os alunos que se preparam durante todo o semestre para este dia.

Infelizmente, mesmo com todo este esforço, a participação dos pais ainda é pequena na vida escolar dos alunos, porém tem havido melhora desde a implementação deste projeto.

Neste final de bimestre, além do "Dia da Família", foi realizada a "Festa Julina”. É interessante ressaltar que houve grande envolvimento de todos os alunos e professores para o sucesso da festa. Outro aspecto de extrema importância que manifesta a intenção de redução das desigualdades sociais é o modo de organização das festas, ocasião em que todos os alimentos arrecadados são para o consumo de todos. Nas festas tudo é gratuito, não havendo, portanto, distinção econômica no acesso dos alunos às comidas e bebidas ofertadas aos presentes. 


\section{4- Escola, democracia e cidadania}

Nesta parte do estudo serão tratadas questões vinculadas à noção de cidadania, direitos, democracia e a postura da escola em relação à formação de cidadãos.

Os entrevistados, em geral, tenderam a atrelar a noção de cidadania no Brasil à luta por direitos, ao cumprimento dos deveres, à autonomia e à participação.

Em relação aos direitos humanos, foi possível perceber a falta de conhecimento de uma definição precisa do tema, apesar dos professores possuírem um certo senso comum sobre o assunto. Respeito ao outro, ponto de partida para uma sociedade mais justa, proteção ao ser humano, liberdade e defesa contra abusos são algumas das respostas obtidas.

Todos os entrevistados afirmaram conhecer, em alguma medida, seus direitos de cidadãos. Os mais destacados são os direitos fundamentais previstos no $\mathrm{Art} .5^{\circ} \mathrm{da}$ Constituição Federal de 1988: voto, ir e vir, liberdade de opinião e expressão, trabalho, moradia, saúde, segurança e educação.

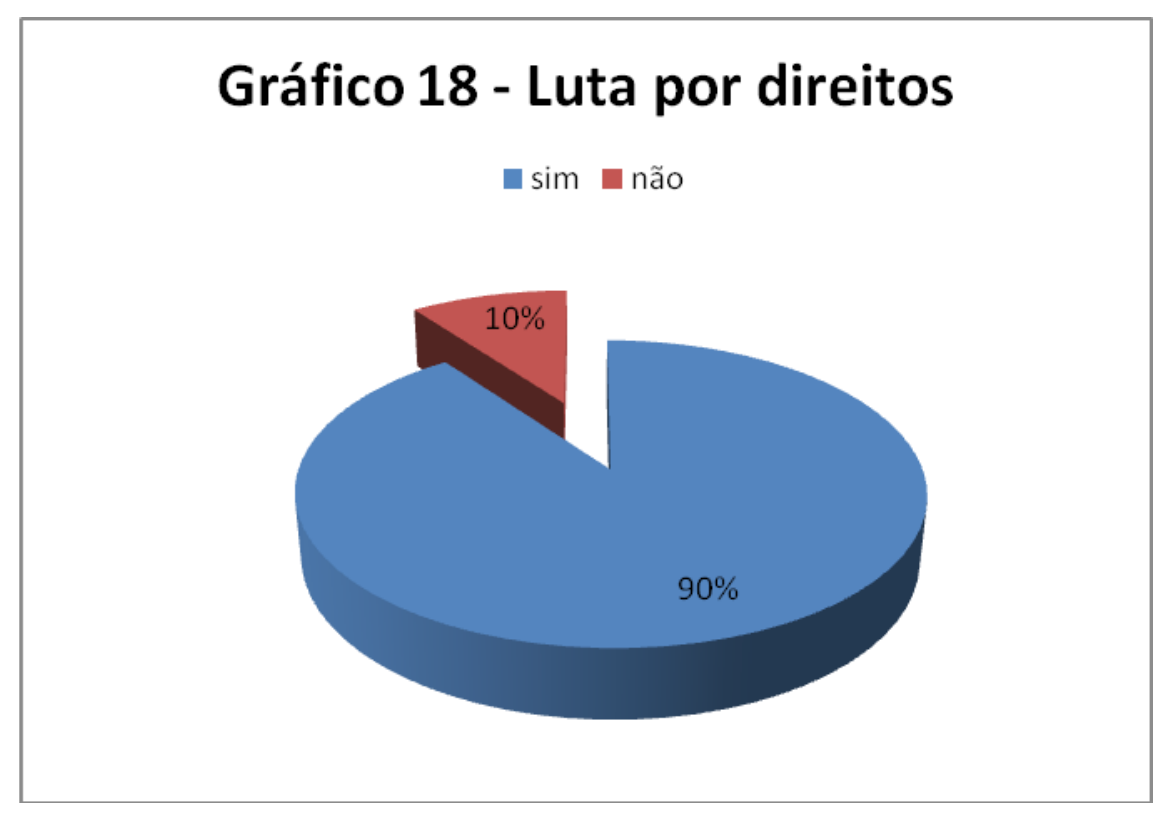

Somente um professor afirmou não lutar pelos seus próprios direitos. Para aqueles que lutam (90\%) as principais ações realizadas são: 1) uso do voto como instrumento 
de escolha de representantes defensores dos interesses da população; 2) contato direto com os candidatos eleitos para solicitar apoio às suas reivindicações; 3) solicitação de auxílio dos órgãos responsáveis pela proteção de direitos como o PROCON e o Ministério Público; 4) contato com ouvidorias de órgãos públicos e privados para denunciar a violação de direitos; 5) utilização de e-mails para solicitar providências relacionadas a direitos.

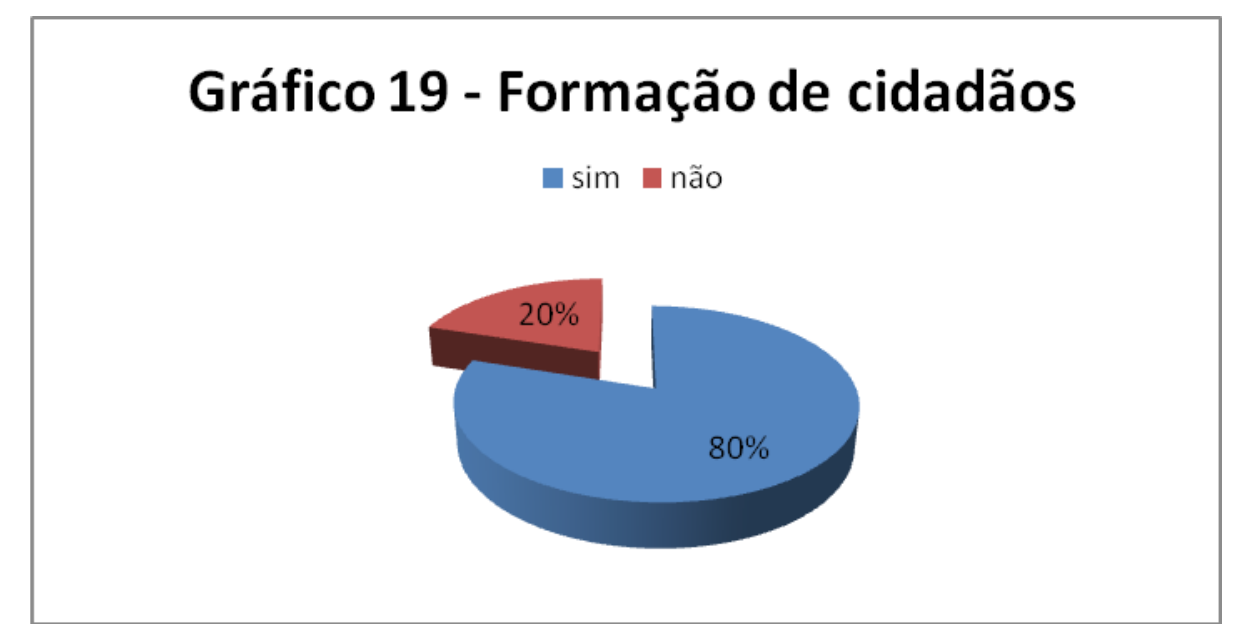

Oitenta por cento dos professores (8) entrevistados reconheceram que o CEF 01 está preocupado com a formação para a cidadania. Ressaltaram que a escola desenvolve projetos interdisciplinares voltados para a formação de valores e que o PPP aborda temas transversais no dia-a-dia dos alunos, também relacionados à cidadania: questões de ética, meio-ambiente. Foi apresentada a sugestão de desenvolver projetos específicos que abordassem, de maneira mais direta, os direitos humanos, a cidadania e os valores para que a abordagem destes temas se desse de maneira contínua, não dependendo apenas da vontade dos professores. 


\section{Gráfico 20 - Democracia no Brasil}

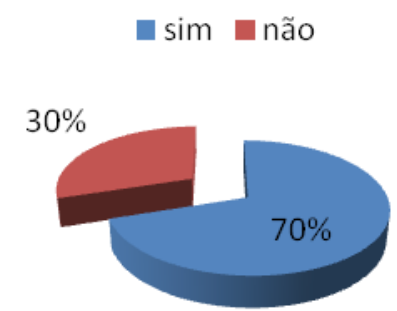

Dois terços dos docentes entrevistados (30\%) reconheceram a existência de democracia no Brasil e apenas três professores fizeram ressalvas, afirmando que a democracia existente não é global e há muita desigualdade social no país. Interessante observar que, mesmo fazendo restrições ao processo democrático do país, os docentes mantêm uma postura crítica em relação ao processo político e às diferenças de condição social entre os diversos estratos da sociedade.

Todos (10) responderam que no CEF 01 há práticas democráticas porque há respeito ao outro, liberdade de expressar opiniões e dar sugestões; os alunos são ouvidos, tratados com respeito e de forma igualitária; as decisões são tomadas em conjunto pela comunidade escolar e estão previstas no regimento interno; existe diálogo entre a direção e os professores. Alguns exemplos foram citados: os alunos participam por meio do representante de turma e dos conselhos de classe; parte dos professores dá aos alunos a oportunidade de serem avaliados, demonstrando interesse pela opinião dos alunos a respeito do trabalho desenvolvido pelo professor. 


\section{5- Escola e educação em direitos humanos}

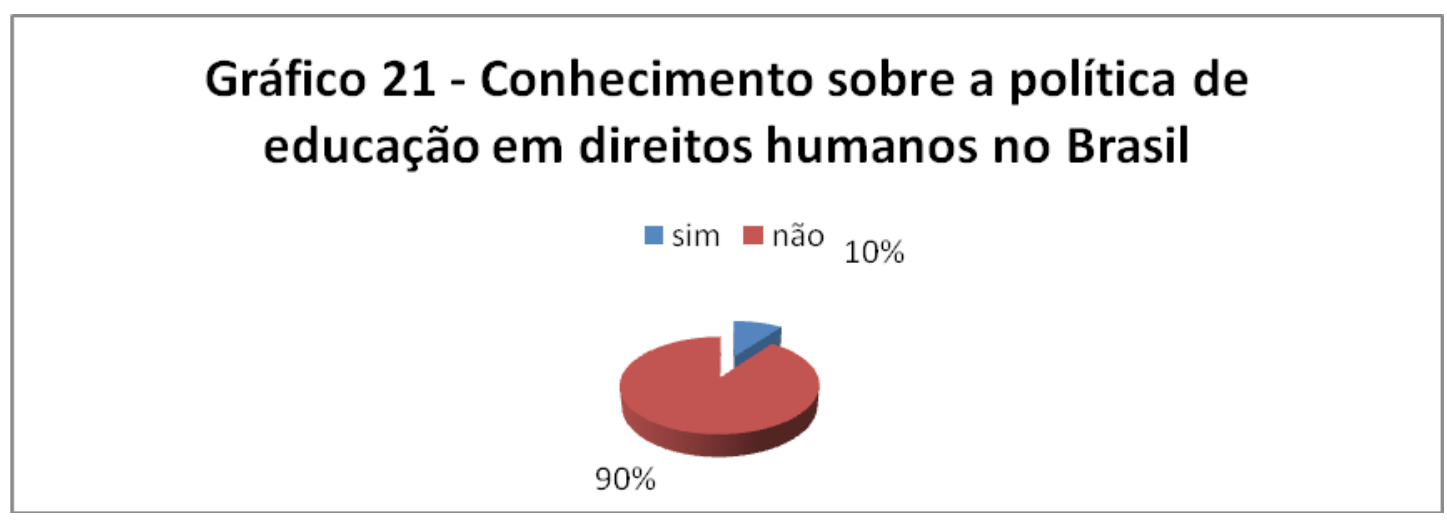

Somente um professor (10\%) alegou conhecer alguma política pública voltada para a educação em direitos humanos, mas classificou como tal os programas de profissionalização de $2^{\circ}$ grau. Neste caso, não demonstra ter conhecimento desta política, o que leva a inferir que a educação em direitos humanos permanece praticamente ausente da agenda escolar e docente.

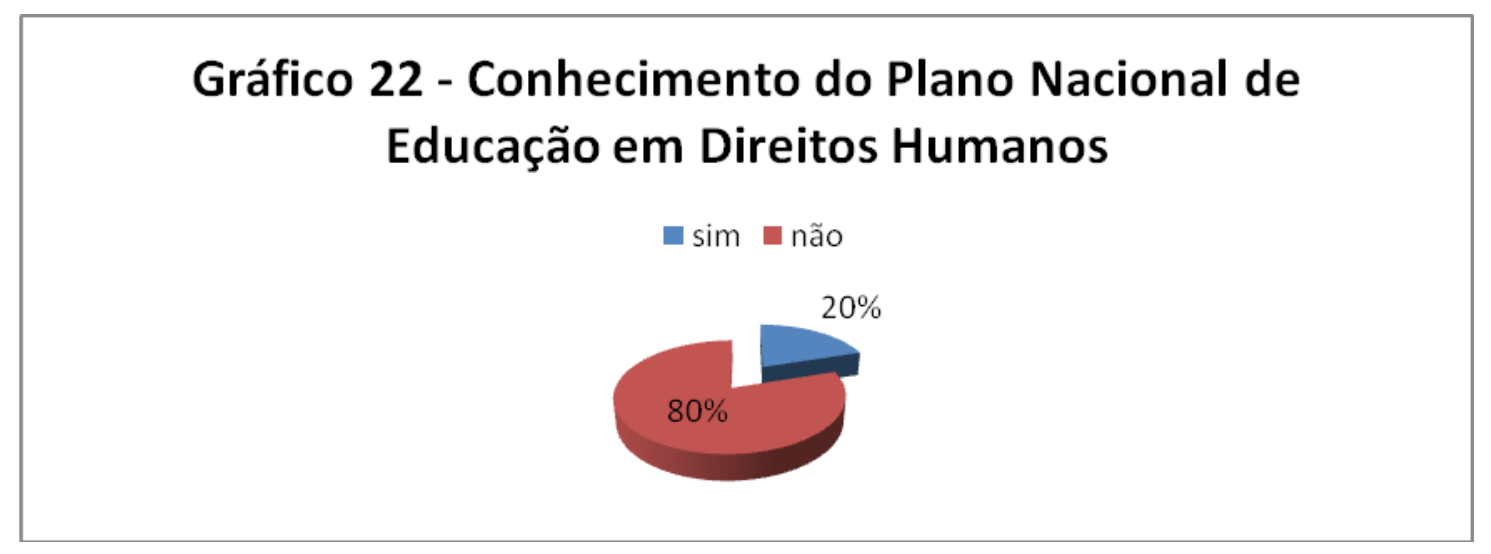

Somente a diretora e uma professora afirmaram conhecer o Plano Nacional de Educação em Direitos Humanos. Os demais entrevistados afirmaram que nunca tomaram conhecimento de sua existência. Ao serem interrogados sobre a implementação de um plano desta natureza, afirmaram que este deveria ser divulgado aos professores por meio de palestras e/ou seminários. Houve ainda a sugestão de incluir o plano no currículo escolar e talvez até transformá-lo em uma disciplina sistematizada, mas fizeram uma ressalva, alegando possível falta de interesse institucional na efetivação ou implementação do plano nas escolas. 


\section{Gráfico 23 - Reconhecimento dos alunos como sujeitos de direitos}

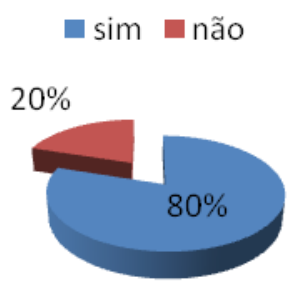

A maioria dos docentes entrevistados (80\%) acredita que a escola reconhece os alunos como sujeitos de direitos, uma vez que está presente na agenda escolar o respeito e o diálogo, sendo que circula no espaço escolar a idéia dos alunos serem a prioridade da instituição. Os que não concordam com esta visão, afirmaram que o paternalismo está muito presente nas relações dos gestores e professores para com os alunos.

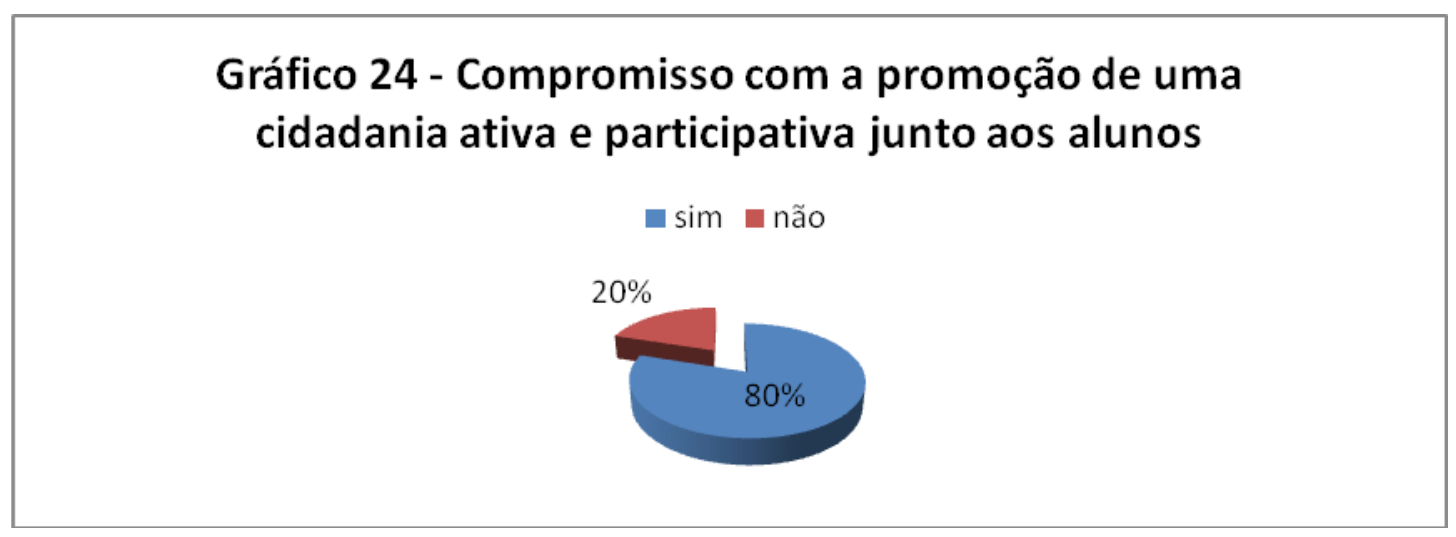

Todos os entrevistados atribuem enorme importância ao incentivo para a adoção, por parte dos alunos, de atitudes, sentimentos e práticas sociais que favoreçam o reconhecimento da igualdade de direitos e o respeito às diferenças, atributos imprescindíveis à formação de uma sociedade justa, inclusiva e igualitária. Entretanto, ao nível do compromisso da escola com a promoção de uma cidadania ativa e participativa junto aos alunos, $80 \%$ responderam afirmativamente e $20 \%$ deram respostas negativas à questão. 


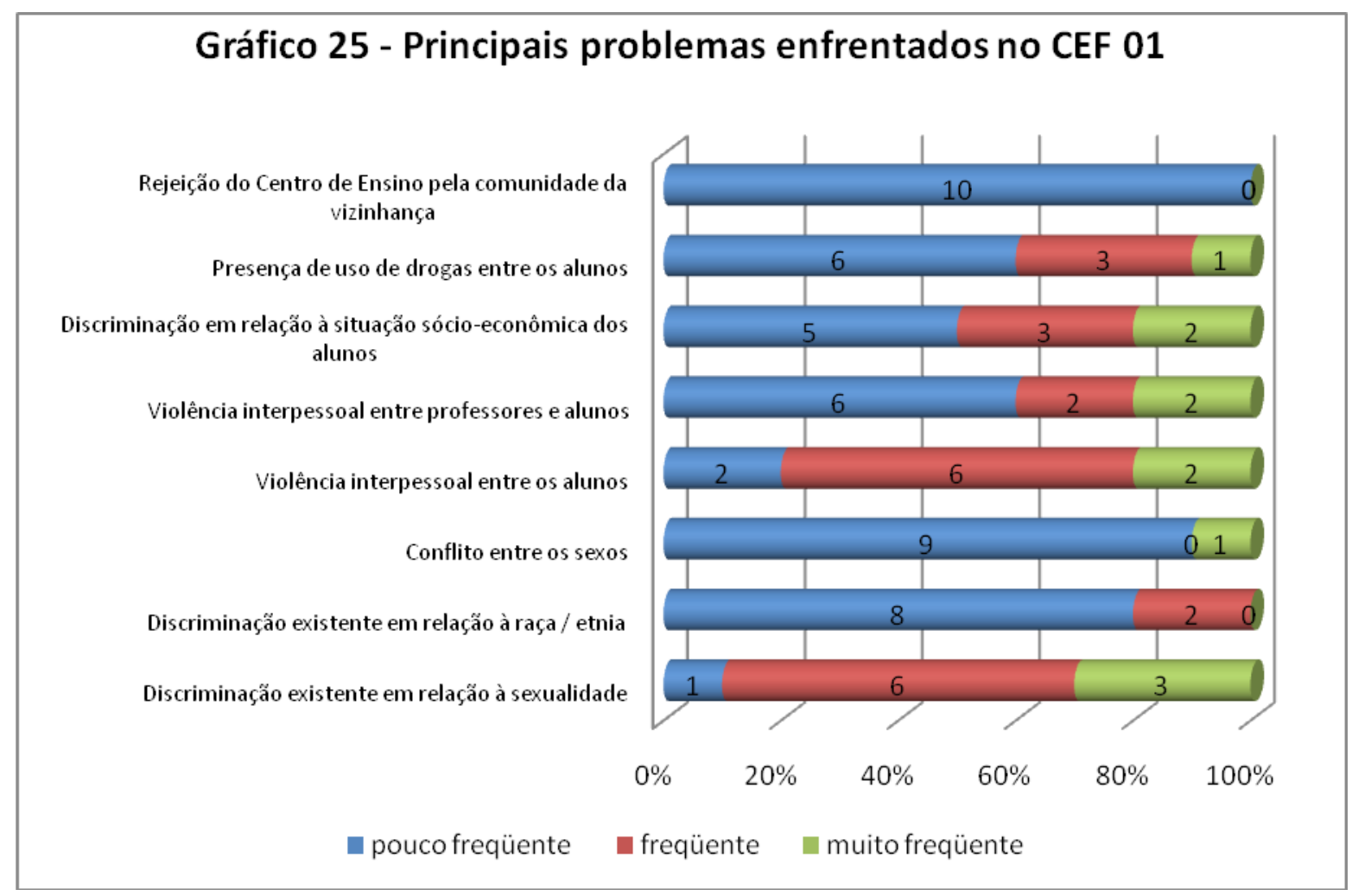

Conforme demonstra o Gráfico 26, as categorias relacionadas à discriminação em relação à sexualidade e à violência interpessoal entre os alunos ocupam posições de destaque entre os principais problemas enfrentados na escola. Por outro lado, a comunidade local não manifesta rejeição à presença da escola na sua vizinhança, o que é altamente positivo, tendo em vista a situação de rejeição em outras unidades escolares do DF.

A presença do uso de drogas entre os alunos, a discriminação em relação à situação sócio-econômica e a violência interpessoal entre professores e alunos ocupam posição de média relevância, o que parece favorecer relações interpessoais mais amistosas e solidárias.

Também foi constatada pouca freqüência de situações de discriminação em relação à raça/etnia e de conflito entre os sexos, fato que expressa certa tolerância e respeito ao outro nas relações sociais. Os professores relataram que em situações de conflito, fazem primeiro o uso do diálogo. Caso não se obtenha sucesso, o problema é encaminhado à direção. 
Ressaltaram que geralmente resolvem os conflitos em sala de aula, sem necessidade de tomar medidas mais enérgicas, pois é muito comum a situação ficar sob controle após a abertura de diálogo entre professores e alunos.

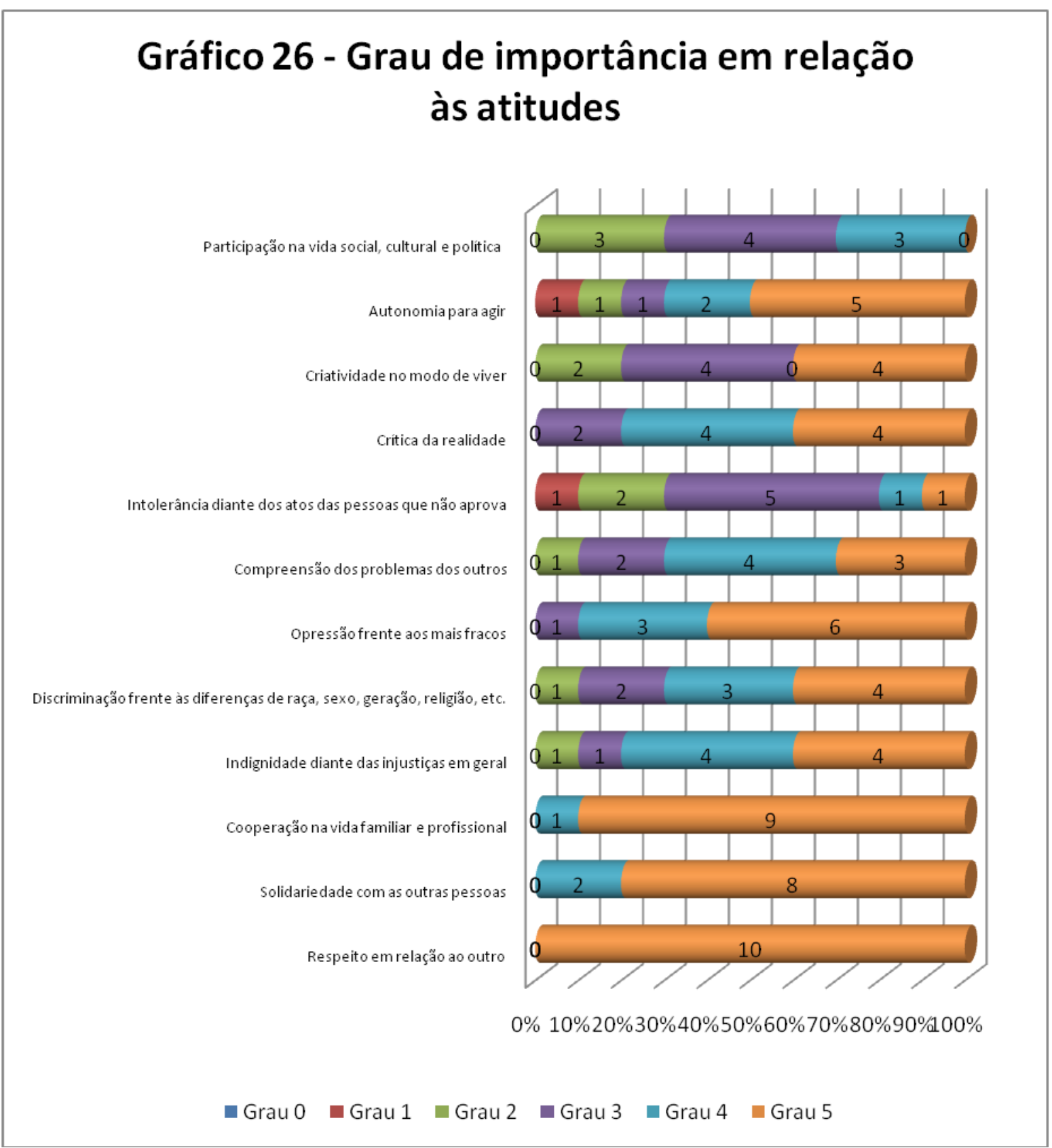

As atitudes apresentadas acima representam bases ou predisposições comportamentais presentes nas relações sociais. Todos os entrevistados admitiram a máxima importância ao respeito, $90 \%$ à cooperação familiar e profissional e $80 \%$ à solidariedade com 
as outras pessoas. Estas três atitudes refletem de certo modo a configuração de um ambiente escolar satisfatório para a convivência social, em uma perspectiva democrática e cidadã.

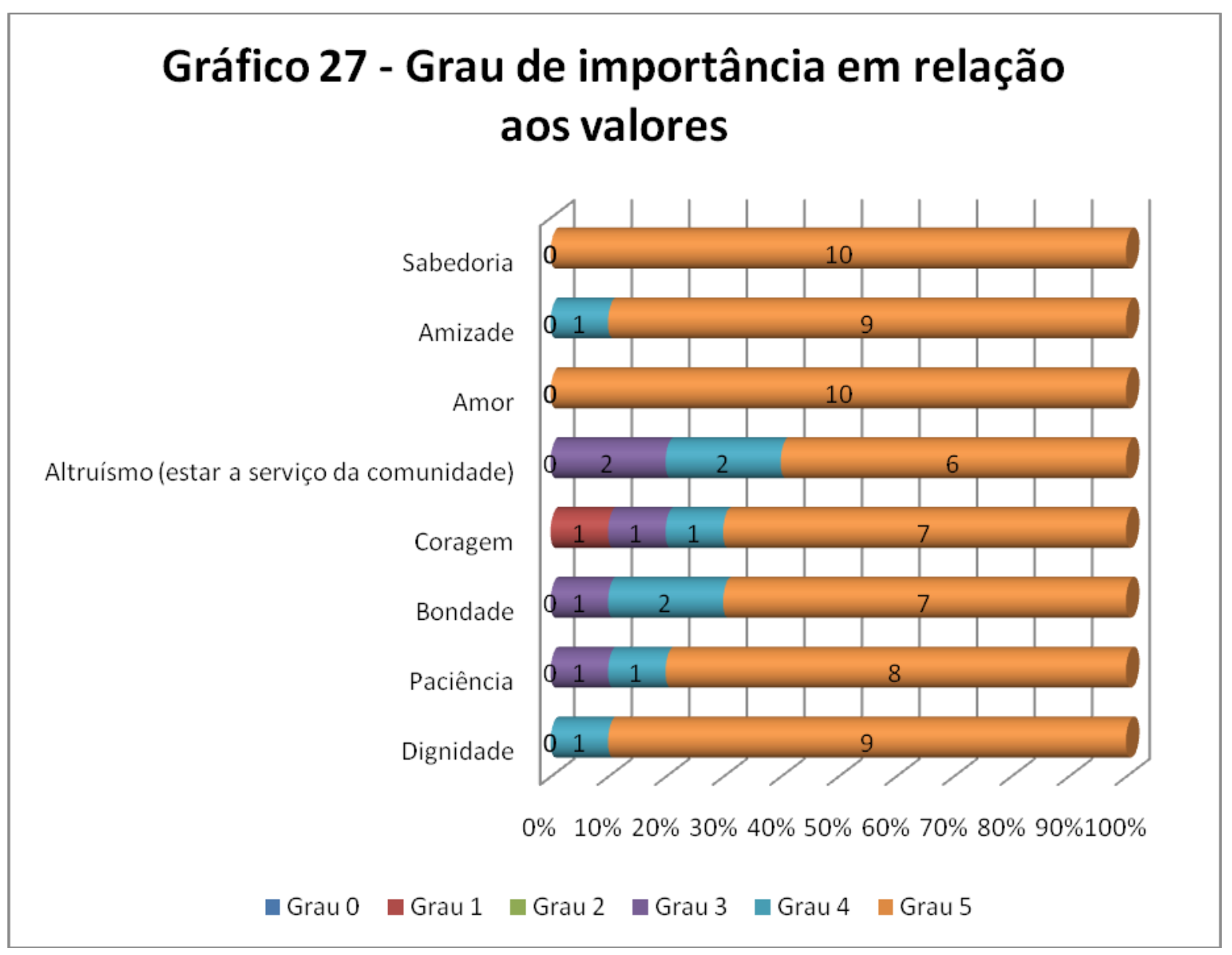

Dentre os valores mais importantes relatados pelos docentes, o amor e a sabedoria ocupam lugar de destaque, obtendo 100\% de máxima importância, o que revela uma predisposição de afeto e discernimento na convivência social, além da busca de equilíbrio no modo de viver. A amizade e a dignidade (90\%) juntamente com a paciência (80\%) constituem aspectos relevantes para a construção de um ambiente escolar pautado por relações de respeito, calma e solidariedade. Em seguida, a coragem e a bondade $(70 \%)$, somadas ao altruísmo (60\%), revelam que os docentes entrevistados valorizam virtudes preciosas para o exercício da profissão de educador(a).

Com base nesses dados, pode-se verificar que a construção de valores por parte dos profissionais de ensino desta escola é propícia ao sucesso no processo educativo, 
uma vez que os valores e atitudes implícitos nos comportamentos, discursos e ações parecem influenciar de maneira positiva os alunos durante o convívio na escola.

\section{6- Educação em direitos humanos e projeto político-pedagógico}

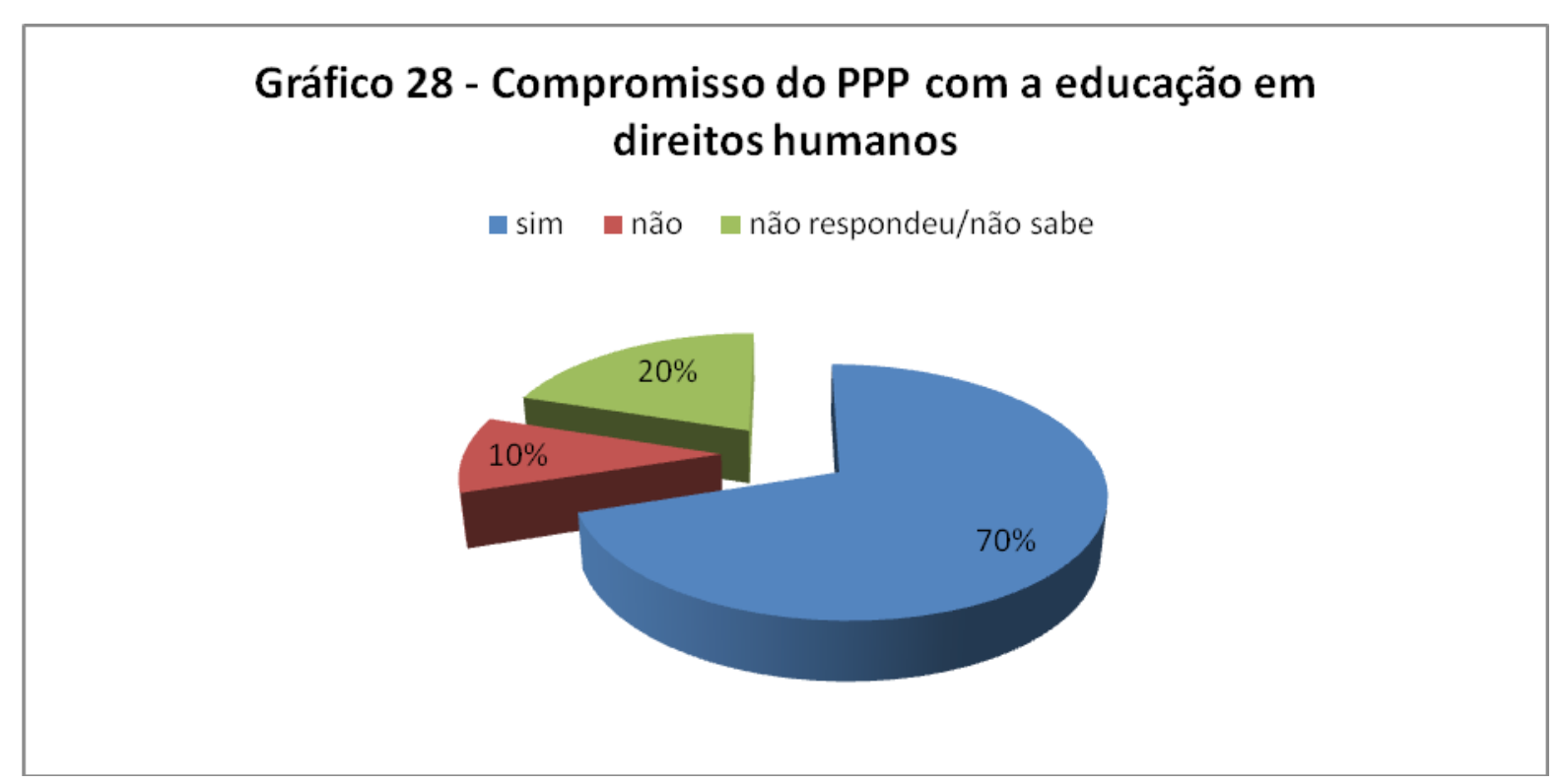

Dos 10 professores, 7 (70\%) responderam que o PPP do CEF 01 possui compromisso com a educação em direitos humanos, 2 (20\%) negaram e $1(10 \%)$ respondeu não ter conhecimento do PPP da escola, por estar trabalhando há pouco tempo no CEF 01. Neste sentido, o potencial educativo na linha dos direitos humanos se revela bastante promissor.

Quanto às finalidades sociais, culturais, políticas, profissionais e humanísticas da escola, os entrevistados relataram que o CEF 01 possui o papel de contribuir para a formação de cidadãos conscientes e capazes de transformar a sociedade. Além disso, a escola promove eventos culturais com diversas manifestações artísticas como dança, música, poesia, pintura e teatro desenvolvidos pelos próprios alunos e apresentados em diferentes momentos como nas festas e reuniões de pais. A formação para a cidadania foi ressaltada como finalidade política. 
Profissionalmente, os professores não identificaram objetivos que estão sendo cumpridos pela escola, considerando o fato da mesma atender somente alunos do ensino fundamental. Alguns, porém, reconheceram que esta fase da formação do aluno é a base para o desenvolvimento de um bom profissional. Do ponto de vista humanístico, o CEF 01 possui a meta de reduzir as desigualdades sociais e formar cidadãos solidários.

O funcionamento da estrutura pedagógica da escola foi classificado, de modo geral, como satisfatório. Alguns ressaltaram a escassez de recursos financeiros e a falta de autonomia por parte da escola para direcionar os recursos para necessidades específicas tais como a reforma da quadra de esportes, etc. Em geral, os recursos vêm atrelados a projetos que, muitas vezes, não são prioritários para a escola.

Outro aspecto interessante abordado na pesquisa foi o conteúdo das disciplinas. Os professores relataram que os livros didáticos às vezes não possuem os assuntos correspondentes ao conteúdo curricular do DF. O Ministério da Educação (MEC) disponibiliza os livros e o GDF elabora o currículo, sem observar se há uma adequada correspondência de assuntos/temas a serem abordados nas disciplinas.

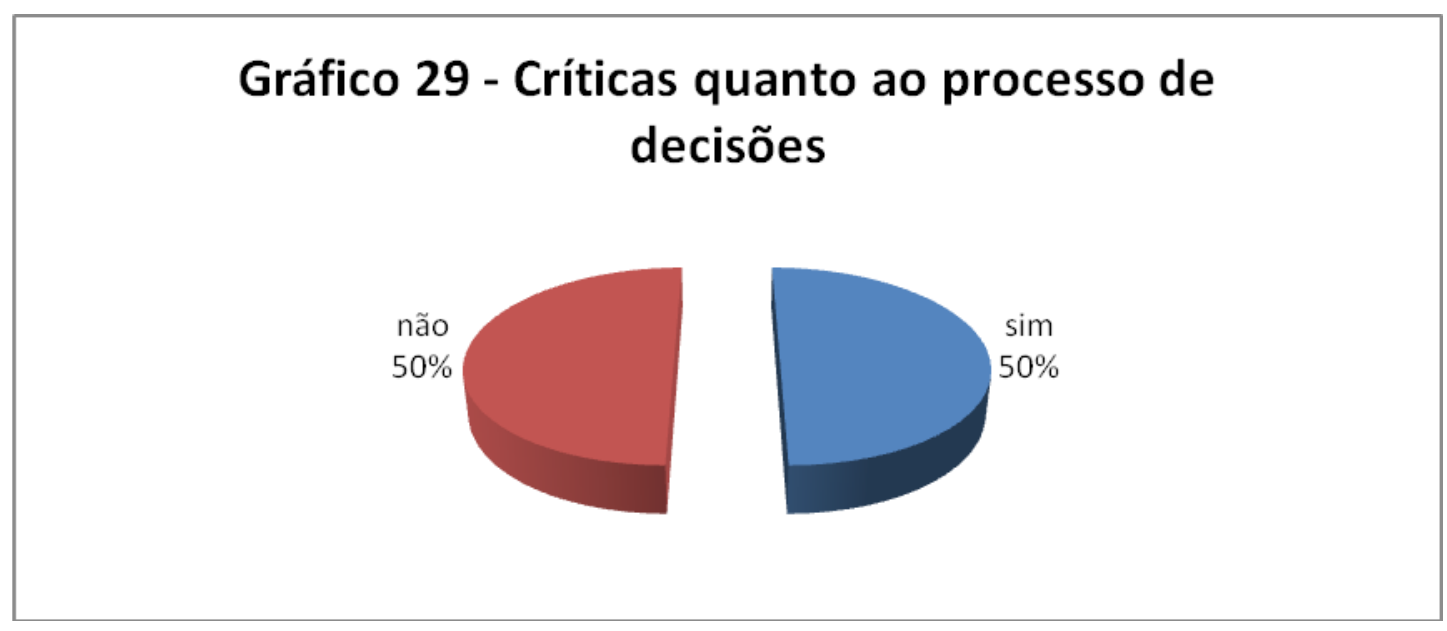

Metade dos professores (50\%) está satisfeita com o processo de tomada de decisões na escola. Uma crítica importante foi a falta de autonomia da direção, que se vê prejudicada até mesmo em situações simples: se um aluno desobedece ao regimento escolar 
indo para a escola sem uniforme, a direção não pode interferir porque o Ministério Público intervém, determinando que a escola aceite aquele aluno. Outra situação mencionada foi o caso das suspensões e expulsões da escola. Quando alguma situação extrema acontece, a escola não pode punir os alunos com suspensão nem expulsão. O máximo que se pode fazer é transferir o aluno de escola o que, na visão dos professores, significa não resolver o problema apresentado pelo comportamento do aluno transferido.

Quanto aos recursos didático-pedagógicos, estes parecem atender satisfatoriamente às necessidades das disciplinas e as salas de aulas também se mostram adequadas, visto que a escola desenvolve um projeto de sala-ambiente (salas fixas para cada disciplina), permitindo aos professores e alunos construírem um ambiente propício à disciplina estudada.

Foi ressaltado que a ausência de interesse dos pais em relação à vida escolar dos alunos e a falta de valores construtivos por parte da família são as principais causas da indisciplina dos alunos. Os professores tentam ensinar valores democráticos e cidadãos, educando os alunos para suprir esta lacuna, mas reconhecem que esta função é, principalmente, da família.

O PPP da escola é avaliado bimestralmente, o que é bastante valioso para favorecer reflexões, discussões e possíveis adaptações necessárias ao bom desenvolvimento dos projetos. 


\section{8- CONCLUSÃO}

Ao analisar o PPP do CEF 01 pode-se perceber que, longe de possuir a intenção de esgotar a discussão do tema e de entender completamente o universo pesquisado como um todo, para além de suas relações e construções sociais bem como institucionais, foi possível verificar que o tema educação em direitos humanos encontra-se diluído em diversos projetos da escola, mas não de maneira sistematizada em ações ou projetos específicos. Há pouca clareza quanto à educação em direitos humanos, apesar de haver forte intenção, por parte do corpo docente, de transmitir valores e formar cidadãos.

A avaliação continuada do PPP é positiva, visto que ainda há bastante o que acrescentar e rever nas práticas pedagógicas dos docentes e, visto que a construção coletiva deste projeto indica a possibilidade de agregação de outros que visem à formação de cidadãos como sujeitos de direitos, conhecedores dos seus deveres, solidários e capazes de refletirem a respeito da realidade social em que estão inseridos e, de maneira mais profunda, contribuírem para uma mudança dessa realidade.

O conhecimento do Plano Nacional de Educação em Direitos Humanos por parte dos professores, e a conscientização clara de que a educação em direitos humanos tem por objetivo a formação de uma cultura de respeito à dignidade humana, através da promoção e da vivência de valores como igualdade, justiça, solidariedade, cooperação, liberdade, tolerância e paz são de fundamental importância à construção de um projeto políticopedagógico que realmente contemple de maneira satisfatória a educação em direitos humanos.

Em relação à hipótese formulada, pode-se dizer que esta foi confirmada, tendo em vista que: 
1. O PPP não contempla satisfatoriamente o tema em foco, pois não define de maneira clara a questão dos direitos humanos em seus projetos educacionais.

2. Os professores trabalham de forma desarticulada as questões de valores e de cidadania, em virtude de ainda não possuírem um projeto específico de educação em direitos humanos.

Considerando a construção coletiva e democrática do PPP, e admitindo que esta não é isenta da influência de valores, crenças e reflexões críticas daqueles que participam de sua construção, vale ressaltar que, conforme consta nos dados da pesquisa, apesar da ausência de projetos específicos de direitos humanos e de ações coordenadas no sentido da educação em direitos humanos, o CEF 01 possui um corpo docente comprometido não somente com a transmissão de valores, porém, mais do que isso, os professores demonstram por meio de práticas cotidianas uma profunda preocupação com a formação de cidadãos.

\section{9- REFERÊNCIAS BIBLIOGRÁFICAS}

AFONSO, Maria Rosa. Educação em direitos humanos: aspectos da realidade portuguesa. Jornal da Rede Estadual de Direitos Humanos do Rio Grande do Norte. Edição Especial EDH -2006, p.05.

BOAS, Benigna Maria de F. V. O projeto político-pedagógico e a avaliação. In: VEIGA, Ilma Passos e REZENDE, Lúcia M. G. Escola: espaço do projeto político pedagógico. Papirus Editora, Campinas/SP, $8^{\mathrm{a}}$ edição, 2005.

Brasil. Comitê Nacional de Educação em Direitos Humanos. Plano Nacional de Educação em Direitos Humanos. Versão preliminar. -Brasília: Secretaria Especial dos Direitos Humanos, Ministério da Educação, Ministério da Justiça, UNESCO, 2006. 
Brasil. Comitê Nacional de Educação em Direitos Humanos. Plano Nacional de Educação em Direitos Humanos. -Brasília: Secretaria Especial dos Direitos Humanos, Ministério da Educação, Ministério da Justiça, UNESCO, 2007.

BUSSMANN, Antônia C. O projeto político-pedagógico e a gestão da escola. In: VEIGA, Ilma Passos (Org.). Projeto político e pedagógico da escola: uma construção possível. Papirus Editora, Campinas/SP, 14 edição, 2004.

CANDAU, Vera M. Educação em direitos humanos no Brasil: realidades e perspectivas. In: CANDAU, V. M. e SACAVINO, S. Educar em direitos humanos: construir democracia. Rio de Janeiro, DP\& $\&^{\mathrm{a}}$ Ed. 2000.

CAVAGNARI, Luzia Borsato. Projeto político-pedagógico, autonomia e realidade escolar: entraves e contribuições. In: VEIGA, Ilma Passos e REZENDE, Lúcia M. G. Escola: espaço do projeto político pedagógico. Papirus Editora, Campinas/SP, 8 edição, 2005.

Declaração dos Direitos do Homem e do Cidadão 26/08/1789. In: BRANDÃO, Adelino (Org.). Os direitos humanos - antologia de textos históricos. São Paulo: Landy Livraria Editora e Distribuidora LTDA, 2001.

CANDAU, Vera Maria. Educação em direitos humanos hoje. Jornal da Rede Estadual de Direitos Humanos do Rio Grande do Norte. Edição Especial EDH - 2006, p.02.

DELORS, Jacques. Educação: um tesouro a descobrir. São Paulo: Cortez, $3^{\text {a }}$ ed., 1999. DEMO, Pedro. Política social e política educacional. Educação, cultura e política social. Porto Alegre - RS: Editora Feplam, 1979. . Educação e qualidade. Papirus Editora, 2a edição, 1995. . Educação pelo avesso: assistência como direito e como problema. São Paulo:

Cortez, 2000. 
DESLANDES, Suely Ferreira. Pesquisa social: teoria método e criatividade/Suely Ferreira Deslandes, Otávio Cruz Neto, Romeu Gomes; Maria Cecília de Souza Minayo (organizadora). - Petrópolis, RJ: Vozes, 1994.

FALKEMBACH, Elza Maria Fonseca. Planejamento participativo: uma maneira de pensá-lo e encaminhá-lo com base na escola. In: VEIGA, Ilma Passos A. (org). Projeto políticopedagógico da escola: uma construção possível. Papirus Editora, Campinas - São Paulo. 17 edição, 2004.

FREIRE, Paulo. Pedagogia do Oprimido. 17ª ed. Rio de Janeiro: Paz e Terra, 1970. HORTA, Maria Del Mar Rubio. Educar em direitos humanos: compromisso com a vida. In: CANDAU, V. M. e SACAVINO, S. Educar em direitos humanos: construir democracia. Rio de Janeiro, DP\&A Ed., 2000.

LAVILLE, Christian. A construção do saber: manual de metodologia da pesquisa em ciências humanas/Christian Laville e Jan Dionne; trad. Heloísa Monteiro e Francisco Settineri. - Porto Alegre: Editora Artes Médicas Sul Ltda.; Belo Horizonte: UFMG, 1999.

MAANEN, John Van. Reclaiming qualitative methods for organizational research: a preface. In: Administrative Science Quarterly, vol 24, nº 4, 1979.

MAGENDZO K, Abraham. Educación en derechos humanos: un desafío para los derechos de hoy. Ensayo 2006. Santiago: LOM Ediciones, $1^{\mathrm{a}}$ ed., 2006.

MARQUES, Mário O. Escola, aprendizagem e docência: imaginário social e intencionalidade política. In: VEIGA, Ilma Passos A. (org). Projeto político-pedagógico da escola: uma construção possível. Papirus Editora, Campinas - São Paulo. 17ª edição, 2004.

NEVES, Carmen Moreira de Castro. Autonomia da escola pública. In: VEIGA, Ilma Passos A. (org). Projeto político-pedagógico da escola: uma construção possível. Papirus Editora, Campinas - São Paulo. 17ª edição, 2004. 
SANTIAGO, Anna Rosa F. Projeto político-pedagógico da escola: desafio à organização dos educadores. In: VEIGA, Ilma Passos A. (org). Projeto político-pedagógico da escola: uma construção possível. Papirus Editora, Campinas - São Paulo. 17ª edição, 2004.

SANTIAGO, Anna Rosa F. e ZASSO, Silvana Maria B. Projeto político-pedagógico: a experiência de uma escola de periferia urbana na construção de sua identidade. In: VEIGA, Ilma Passos A. (org). Projeto político-pedagógico da escola: uma construção possível. Papirus Editora, Campinas - São Paulo. 17 edição, 2004.

TOSI, Giuseppe (Org.). Direitos humanos: história, teoria e prática. João Pessoa: Editora Universitária/UFPB, 2005.

VEIGA, Ilma P. A. Educação básica e educação superior: projeto político-pedagógico. Campinas - São Paulo: Papirus, 2004, capítulos 01 e 02.

VEIGA, Zilah de Passos Alencastro. As instâncias colegiadas da escola. In: VEIGA, Ilma P. A. e RESENDE, Lúcia M. G. Escola: espaço do projeto político-pedagógico. Papirus Editora, Campinas - São Paulo. $8^{\mathrm{a}}$ edição, 2005.

VEIGA, Ilma Passos Alencastro. Educação básica: projeto político-pedagógico. Papirus Editora, Campinas - São Paulo. 8 a edição, 2005.

WARAT, Luis Alberto. Direitos Humanos: Subjetividade e práticas pedagógicas. In: SOUSA, JR et al. (orgs). Educando para os direitos humanos: Pautas Pedagógicas para a Cidadania na Universidade. Brasília. Editora Síntese. 2003. 
10- ANEXOS 
Subsecretaria de Estado de Educação do Distrito Federal

Subsecretaria de Suporte Educacional

Gerência Regional de Ensino de Sobradinho

Centro de Ensino Fundamental 01 de Sobradinho - CEF 01

\section{Projeto Político-pedagógico 2007-2008}

Sobradinho - DF 


\section{SUMÁRIO}

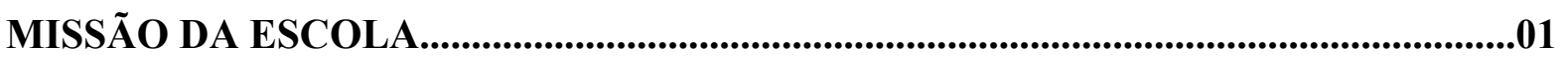

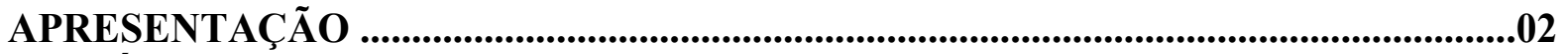

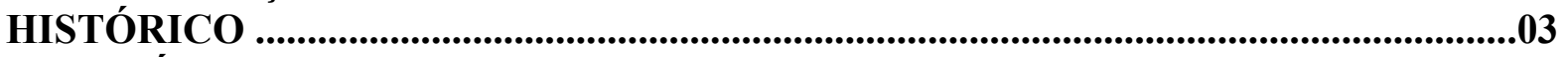

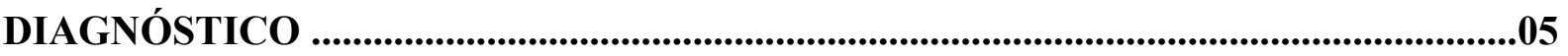

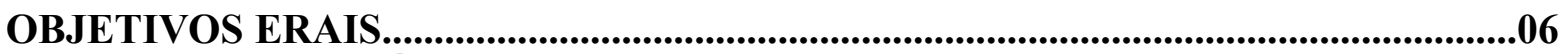

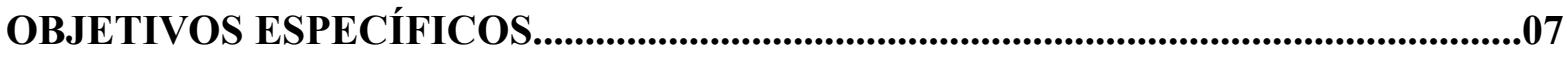

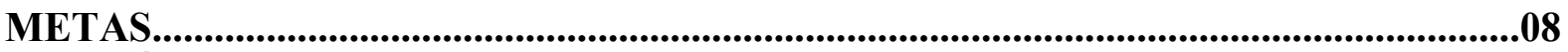

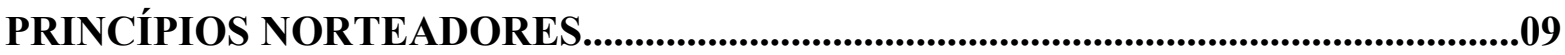

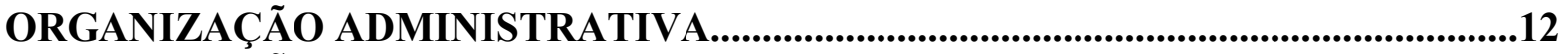

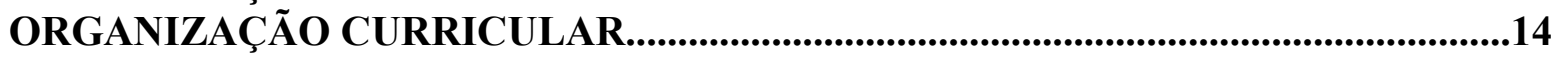

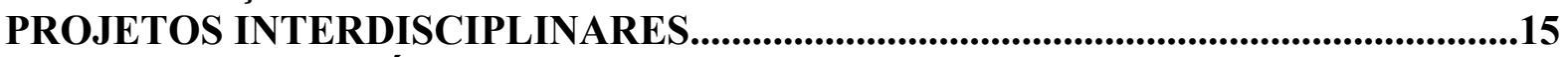

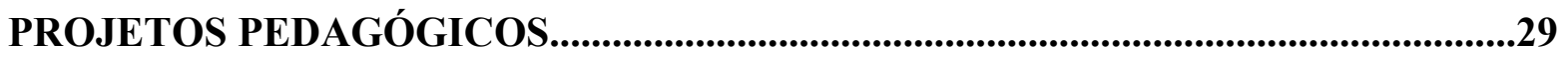

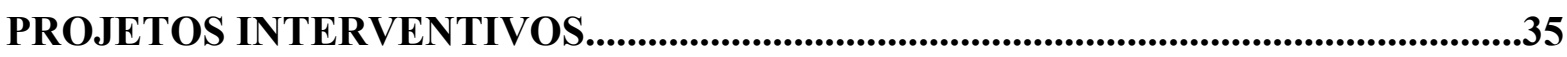

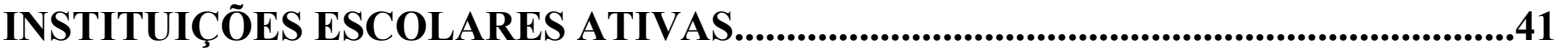

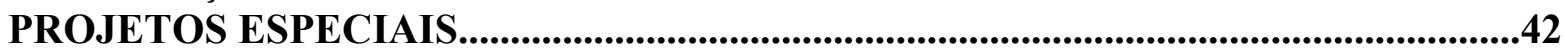

AVALIAÇÃ 


\section{APRESENTAÇÃO}

A presente proposta visa ao aprimoramento de ações adotadas e também a implementação de novas iniciativas que conduzam à elevação do nível de aprendizagem dos alunos e a uma integração interdisciplinar mais efetiva.

Para obtenção dos objetivos propostos há necessidade da implantação de diversos projetos pedagógicos dentre os quais enfatizamos os seguintes:

\section{Meio Ambiente}

A diversidade de seres vivos existentes, as relações de dependência e outros aspectos devem ser considerados significativos para formação de uma consciência crítica do aluno no papel de preservação do meio ambiente proporcionando um desenvolvimento sustentável.

\section{Sexualidade na Adolescência}

Diante das modificações com relação aos valores morais que vêm ocorrendo ao longo das gerações faz-se necessário uma nova abordagem com relação à Educação Sexual no âmbito escolar.

Em tempos passados o assunto sexo era considerado "TABU", tanto na escola como no convívio familiar, o que dificultava a educação sexual dos jovens. A liberação proporcionada através dos meios de comunicação veio, em muitos casos, acarretar uma banalização e conseqüente degradação dos valores sociais. Tendo em vista a nova realidade e a necessidade de adequação das ações que visem proporcionar ao jovem uma visão realística, natural e livre de distorções. 


\title{
DIRETORA
}

FRANCISCA APARECIDA FERNANDES

\section{VICE-DIRETOR}

YARA LÚCIA DE OLIVEIRA

\section{ASSISTENTE ADMINISTRATIVO}

JOSÉ EVANGELISTA DE ARAÚJO

\section{ASSISTENTE PEDAGÓGICO}

DJALMA MARCOS DA SILVA

SECRETÁRIO ESCOLAR

HENRIQUE CÉSAR ARRAZ BRITO

\author{
COORDENADORES \\ ÂNGELA ALVES DE ABREU \\ KÁTIA ALVES DE LUCENA
}

Endereço da Unidade de Ensino Quadra 02 conjunto C/D lote F - Sobradinho-DF CEP 73.015.020 


\section{MISSÃO DA ESCOLA}

As novas mudanças que o mundo vem experimentando, remetem a escola a uma profunda reflexão alusiva a sua prática educacional.

Baseada nesta reflexão global é que buscamos aprimorar as ações adotadas anteriormente e também implementar novas iniciativas que conduzam a elevação do nível de aprendizagem dos alunos e uma integração disciplinar mais efetiva, procurando assim preparar o educando para viver plenamente a cidadania cumprindo seus deveres e usufruindo seus direitos.

Promover o sucesso do aluno, incentivando o prazer de aprender, e assim estaremos erradicando a cultura da repetência.

Manter-se vinculada à comunidade, atendendo seus anseios, partilhando decisões e compartilhando resultados. Parceria esta que resultará no sucesso da aprendizagem, preservação do patrimônio público, auxílio nas dificuldades encontradas no cotidiano, onde a comunidade sentir-se-á prazerosa em colaborar. 


\section{HISTÓRICO DA ESCOLA}

Situado à Quadra 02 conjunto $\mathrm{C} / \mathrm{D}$ lote $\mathrm{F}$, o Centro de Ensino Fundamental 01 de Sobradinho, funcionando em dois turnos (matutino/vespertino), atendendo alunos de $4^{\mathrm{a}}$ e $5^{\mathrm{a}}$ à $8^{\mathrm{a}}$ séries.

Iniciou suas atividades em:

Ano de Construção - 1972

Recebimento do prédio: 09/11/1972

Data de inauguração: 22/03/1973

Natureza do ato: Criação Instrução no 03 de 15/03/1973

Júlio de Castilhos Cachapuz de Medeiros

Presidente da FEDF na época.

Autorização de funcionamento: Reconhecido pela portaria no 17 de 07/07/1980.

Datas de funcionamento e diretores que por aqui passaram:

1972 a $1973 \Rightarrow$ Lucy Sezana

1974 a $1975 \Rightarrow$ Marília Martins Rezende

1976 a $1979 \Rightarrow$ Marilda Lopes Martins

1980 a $1984 \Rightarrow$ Nadir Pereira de Araújo

1985 a $1988 \Rightarrow$ Zita de Almeida e Silva

1989 a $1991 \Rightarrow$ Marília Geraldes de O.L. Bezerra

1992 a $1994 \Rightarrow$ Vera Lúcia Bremmer Sampaio

1995 a $1997 \Rightarrow$ René Silva de Bitencourt

1998 a $1999 \Rightarrow$ Carivaldo João da Silva

2000 a $2007 \Rightarrow$ Francisca Aparecida Fernandes

Atualmente sob a direção da vice-diretora, Professora Yara Lúcia de Oliveira (aguardando nomeação), o Centro de Ensino Fundamental 01 de Sobradinho atende 622 alunos, sendo 305 no matutino ( $4^{\mathrm{a}}, 7^{\mathrm{a}}$ e $8^{\mathrm{a}}$ séries $)$, e 317 no vespertino $\left(4^{\mathrm{a}}, 5^{\mathrm{a}}\right.$ e $6^{\mathrm{a}}$ séries $), 25$ professores, 02 coordenadores assistente de educação, 02 coordenadores de área, 08 servidores de conservação e limpeza, 04 merendeiras, 03 vigias, 02 porteiros, 01 secretário, 02 Especialistas em educação, 01 diretora, 01 vice-diretor.

A sua estrutura física hoje é a seguinte: 12 salas de aula, 01 salas especiais, 01 biblioteca, 01 secretaria, 01 direção, 01 sala onde funciona o áudio e o administrativo, 01 sala de professores com copa, 02 banheiros para professores, 01 banheiro para deficiente, 01 depósito de educação física, 02 banheiros para educação física, 01 depósito de material, laboratório de informática (em implantação), 01 sala de coordenação, 01 cantina conjugada com o depósito de merenda, 01 pátio coberto, 02 banheiros para alunos, 01 sala de vídeo/múltiplas funções, 01 depósito de material de limpeza, 02 banheiros para servidores, 01 sala para servidores, 01 guarita, 01 quadra esportiva (necessitando de reparos e cobertura). 


\section{OBJETIVOS GERAIS}

Desenvolver um trabalho construtivo baseado no novo currículo de Educação Básica, visando tornar a prática educativa mais eficiente, dinâmica, buscando assim a melhoria da qualidade do ensino na aprendizagem e a educação como um todo.

Gerenciar de forma criativa e participativa, os recursos destinados ao bem estar da comunidade escolar, a manutenção e conservação do patrimônio público sob nosso gerenciamento, tornando o ambiente de trabalho agradável e propício à aprendizagem. 


\section{OBJETIVOS ESPECÍFICOS}

Desenvolver um trabalho consciente e seguro de seus objetivos, garantindo assim um melhor desempenho pedagógico compromissado com a educação.

Fazer da coordenação pedagógica um momento de reflexão e organização das atividades desenvolvidas coletivamente para um bom desempenho curricular através da interdisciplinaridade.

Proporcionar ao aluno, através da recuperação contínua e formativa a oportunidade de adquirir o conhecimento dos conteúdos não apreendidos anteriormente.

Orientar atividades que desenvolvam o crescimento intelectual e sóciocultural.

Oferecer ao aluno oportunidade de expressar sua criatividade e patriotismo, através de atividades cívicas culturais.

Promover o entrosamento escola comunidade, através de eventos sócioculturais.

Promover reflexões sobre o papel da tecnologia e da ciência para formar a construção do saber de forma crítica e seletiva.

Estimular o corpo docente e discente a utilizar o laboratório de informática a fim de aprimorar o conhecimento.

Proporcionar recuperação paralela aos de $5^{\mathrm{a}}$ a $8^{\mathrm{a}}$ séries.

Orientar procedimentos e atitudes que determinem uma melhor forma de valorização do indivíduo, exercendo o respeito mútuo e a responsabilidade para com os outros.

Implantar projetos pedagógicos que contribuam para a melhoria do rendimento escolar.

Oferecer oportunidades para que o Conselho Escolar possa atuar. 


\section{METAS}

Temos como meta primeira nesta proposta implantar o Currículo da Educação Básica das Escolas Públicas do Distrito Federal.

Capacitar lideranças entre os adolescentes.

Incentivar a participação dos representantes de turmas na disciplina e organização da escola.

Incentivar a Coordenação Pedagógica local.

- $\quad$ Realizar o Recreio Orientado/Rádio Musical.

- $\quad$ Realizar a Semana de Prevenção ao uso de drogas.

- $\quad$ Realizar horas cívicas bimestrais.

- Incentivar o aluno a utilizar a internet como meio de pesquisa.

- Implantar dinâmicas para a melhoria da educação e valorização da autoestima dos jovens que compõem a clientela deste centro de ensino.

Dar condições para a atuação do Conselho Escolar.

- Manter a mecanografia de forma que possa imprimir o material necessário e com boa qualidade.

- $\quad$ Motivar o aluno a criar o hábito de leitura.

- $\quad$ Incentivar a participação dos pais na vida escolar de seus filhos. 
RESPONSÁVEIS PELO DESDOBRAMENTO DAS METAS

Direção

- Diretora

- Vice-diretor

- Coordenador-Assistente de direção

- Secretário

Coordenadores pedagógicos

Professores

Auxiliares de educação

Pais

Alunos 


\section{ESTRATÉGIAS}

- Reuniões administrativo-pedagógicas

- Reelaboração do Regimento Interno da Escola

- Integração entre as disciplinas

- Unificação do método de Avaliação

- E outras. 


\section{VALORES E PRINCÍPIOS NORTEADORES}

A educação é um processo dinâmico e deve acompanhar a evolução dos tempos para que não se torne obsoleta e deixe de cumprir o seu importante papel na formação do cidadão crítico e participativo no que diz respeito as questões políticas, sociais e culturais.

Com base nessas considerações, adota como princípios norteadores: A Lei de Diretrizes e Bases da Educação Nacional (Lei 9394/96), os Parâmetros Curriculares Nacionais, o Parecer $n^{\circ} 04$ da Câmara de Educação Básica referente às Diretrizes Curriculares Nacionais para o Ensino Fundamental, a Proposta Pedagógica das Escolas Públicas do Distrito Federal, o Currículo da Educação Básica do Distrito Federal e os Quatro Pilares da Educação - UNESCO.

\section{I - Lei de Diretrizes e Bases da Educação Nacional (Lei 9394/96).}

A nova Lei de Diretrizes e Bases da Educação Nacional, aprovada em 20 de Dezembro de 1996, consolida e amplia o dever do poder público para com a educação em geral e em particular para com o ensino fundamental, assegurando a todos "a formação comum indispensável para o exercício da cidadania e fornecer-lhes meios para progredir no trabalho e em estudos posteriores" fato que confere ao ensino fundamental, ao mesmo tempo, um caráter de terminalidade e de continuidade.

\section{II - Parâmetros Curriculares Nacionais:}

Os Parâmetros Curriculares Nacionais constituem um referencial de qualidade para a educação no Ensino Fundamental em todo o país. Sua função é garantir o respeito às diversidades culturais, regionais, étnicas, religiosas e políticas que atravessam uma sociedade múltipla, estratificada e complexa.

$\mathrm{O}$ conjunto das proposições expressas nos PCNs responde à necessidade de referências a partir dos quais o sistema educacional do país se organize para que a educação possa atuar, decisivamente, no processo de construção da cidadania. Educação Básica):

III - Diretrizes Curriculares Nacionais (parecer $n^{0} 04$ - Câmara de

As Diretrizes Curriculares Nacionais (29/01/98): é um conjunto de definições doutrinárias sobre princípios, fundamentos e procedimentos na Educação Básica, que orientarão a escola na organização, na articulação e no desenvolvimento das atividades propostas.

\section{IV - Proposta Pedagógica das Escolas Públicas do Distrito Federal:}

A política da Secretaria de Estado de Educação se alicerça no compromisso de ter como centro de interesse o aluno, levando em consideração suas experiências e acrescentando novas aprendizagens significativas e contextualizadas. O C.E.F. 01 com base nestas considerações se compromete em criar condições para que o aluno, além disso, goste da escola; sinta que é respeitado, para poder manifestar-se com confiança.

\section{V - Currículo da Educação Básica das Escolas Públicas do Distrito Federal:}


O currículo das Escolas Públicas do Distrito Federal é um documento compatível com "um novo tempo da educação". A elaboração desse currículo pressupõe o respeito a alguns princípios básicos e importantes para o alcance dos objetivos traçados pelo C.E.F. 01 de Sobradinho.

$>$ Princípio da Interdisciplinaridade - Trata os componentes curriculares de forma integrada, para que o aluno entenda um mesmo fenômeno, sob diferentes pontos de vista.

$>$ Princípio da Contextualização - Tem como ponto de partida a experiência dos educandos, o contexto onde estão inseridos, gerando a partir daí as aprendizagens significativas.

$>$ Valores e Atitudes - Permeiam o currículo em sua totalidade. São determinantes no que diz respeito à conduta e à postura do educando em relação a si próprio, ao outro, à escola e conseqüentemente às situações mais amplas em que esteja envolvido. Neste contexto o corpo docente do C.E.F. 01 dedica-se à discussão e viabilização de estratégias que forneçam a formação de valores e atitudes em seus alunos.

$>$ Desenvolvimento de competências - Compreende a capacidade dos alunos em executar ações e operações mentais que atuem junto aos conhecimentos e experiências adquiridas, gerando as habilidades, ou seja, o saber fazer.

$>$ Avaliação - Deve ser concentrada nas aprendizagens significativas e no progresso do aluno. Essa avaliação deverá caracterizar-se como diagnóstica, processual, contínua, cumulativa e participativa.

\section{VI - OS QUATRO PILARES DA EDUCAÇÃO - UNESCO}

O relatório Jacques Delors, publicado pela UNESCO em 1996, depois de muitas discussões, chegou à conclusão de que pelo menos 04 eixos fundamentais devem nortear a educação no século XXI:

$>$ Aprender a aprender;

$>$ Aprender a fazer

$>$ Aprender a conviver;

$>$ Aprender a ser;

Esses quatro pilares estão presentes na filosofia do CEF 01, pois contribuem para a melhoria da qualidade da educação e abrangem o ser em sua totalidade, do cognitivo ao ético, do estético ao técnico, do imediato ao transcendente. 


\section{ORGANIZAÇ̃̃O ADMINISTRATIVO-PEDAGÓGICO}

\section{DIREÇÃO}

A direção inserida num processo democrático busca a melhoria da qualidade de Ensino numa ação conjunta entre professores, auxiliares de educação, pais e alunos.

\section{CONSELHO ESCOLAR}

O Conselho Escolar é um órgão de apoio ao gerenciamento da Unidade de Ensino.

\section{SECRETARIA}

A secretaria tem por finalidade manterem atualizados e guardados toda a escrituração referente ao funcionamento do Estabelecimento de Ensino e a vida escolar dos alunos.

Atualmente a escola conta com um computador Pentium Celeron 2.4 e uma impressora EPSON matricial FX 890 e um Sistema de Gestão Escolar (SGE), mantido pelo GDF.

\section{COORDENAÇÃO-ASSISTÊNCIA ADMINISTRATIVA}

Os serviços Técnico-Administrativos têm a finalidade de manter em bom funcionamento as atividades administrativas que são constituídas da seguinte forma: Alimentação (merenda escolar), Almoxarifado, conservação e limpeza, portaria, segurança e manutenção.

\section{COORDENAÇÃO-ASSISTÊNCIA PEDAGÓGICA}

Todos os serviços Técnico-Pedagógicos funcionam articulados entre si, visando a integração de toda a comunidade escolar. 


\section{EQUIPAMENTOS}

01 duplicador eletrônico (Risograf 1530)

$>01$ computador e impressora locado pelo GDF

$>01$ computador Pentium 400

$>01$ impressora Deskjet HP $710 \mathrm{C}$

> 04 aparelhos de televisão sendo 1 aparelho 29"

$>03$ aparelhos vídeo cassete

$>05$ aparelhos de som

$>02$ caixas acústicas

$>01$ microfone

$>01$ Mesa de som de 6 canais

$>01$ Amplificador DBK 720

$>01$ Caixa Amplificada STANER

$>01$ Fax Olivetti $485 \mathrm{~T}$

$>02$ retro projetores

$>01$ spring lights

$>$ mapas de todas as disciplinas

$>01$ módulo júnior

$>01$ esqueleto

$>01$ partes do corpo humano em peças anatômicas

$>01$ Home Theater

$>01$ Impressora HP Multifuncional HP 2410

$>$ Data Projector 


\section{1 - PROJETO - SALA DE LEITURA}

CRONOGRAMA - De fevereiro a dezembro de 2007

NÍVEL DE COORDENAÇÃO - * Oficina da Palavra

* Língua Portuguesa

NÍVEL DE ATUAÇÃO - Ensino Fundamental - alunos de $4^{\mathrm{a}}$ a $7^{\mathrm{a}}$ séries

LOCAL - Centro de Ensino Fundamental 01 de Sobradinho

\section{1 - APRESENTAÇÃO}

A linguagem escrita tem características próprias que o aluno não domina completamente. A preocupação com o "erro" acaba por inibir a fantasia, a imaginação, a criatividade (...), por isso este PROJETO SALA DE LEITURA visa capacitar, estimular, formar, modificar a postura do aluno nos hábitos nocivos à história da vida diária e escolar e o convívio da emoção por meio da interação com o meio, com as pessoas significativas que o cercam, expressando-se oral, gráfica, auditiva e visualmente.

\section{2 - JUSTIFICATIVA}

Justifica-se a criação deste Projeto em virtude da mudança da Lei 9.394/96 que sugere autonomia da parte diversificada, adotada pela Comunidade Escolar junto à Escola; seguido em atendimento ao documento expedido pela Secretaria de Estado de Educação que sugere interdisciplinaridade nas disciplinas e finalmente pela necessidade de trabalhar com alunos nas áreas de Produção de Texto, Língua Portuguesa, Geografia e História, ajudando-os a registrar suas idéias criativas e espontâneas.

\section{3 - OBJETIVO}

\subsection{1- GERAL}

Proporcionar aos alunos noções claras de análise de valores, reflexão sobre os temas surgidos, ampliação de sua competência discursiva para atuar nos diversos contextos sociais, favorecendo condições básicas para tomada de decisões responsáveis e estimular o gosto pela leitura.

\subsection{2 - ESPECÍFICOS}

- Aproximar o educando dos textos e os tornar familiares - condição para a leitura fluente, prática de escuta, produção de texto oral e escrito;

- Favorecer a discussão sobre determinado tema, propondo levantamento individual e/ou coletivo de idéias e dados que nortearão a produção de atividades técnicas e literárias;

- Possibilitar o educando a compreender a relação que existe entre a fala e a escrita, identificando a Língua Portuguesa como possuidora de variedades regionais, sociais, culturais, geográficas e discursivas;

- Expandir o conhecimento, contribuindo para a formação de cidadãos sujeitos de si e da história, como agentes criativos e conscientes do processo de produção coletiva do espaço; 
- Informar como escrever e sugerir sobre o que escrever, possibilitando a vivência de emoções, da fantasia e da imaginação, despertando sua curiosidade.

\section{4 - METAS E AÇÕES}

\subsection{1 - METAS}

- Interdisciplinaridade do Projeto Sala de Leitura com a Língua Portuguesa, História e a Geografia, envolvendo Temas Transversais: Ética, Pluralidade Cultural, Orientação Sexual, Meio Ambiente, Trabalho e Consumo, Valores e Atitudes;

- Implantação de uma sala de leitura com textos informativos a fim de que o educando possa se expressar com maior consciência e clareza nas disciplinas que estuda.

\subsection{2 - $\underline{\text { AÇÕES }}$}

- Problemas Sociais:

- Relato de textos com "comentarista de futebol", tecendo opiniões;

- Dramatização de cenas sobre o menor abandonado;

- Confecções de grandes painéis sobre os preconceitos existentes em nossa sociedade;

- Criação de peças teatrais sobre o desemprego;

- Concursos de slogans sobre o analfabetismo;

- Apresentação de parlendas, raps, paródias sobre desigualdade, etc.

- Problemas de Migração:

- Criação de situações que envolvam relatos, apresentação de trabalhos, entrevistas, simulações realizadas entre alunos, professores e convidados a partir dos problemas regionais: físicos, sociais e culturais;

- Problemas Ambientais:

- Produção de jornal - mural para exposição de produção de textos da classe (poéticos, informativos, de opiniões, recados, propagandas de denúncia) sobre o Homem e a Natureza;

- Leitura e escrita de atividades como: cartazes, desenhos, reportagens, relatórios, campanhas educativas sobre o homem e o meio ambiente;

- Proporcionar um ambiente de estímulo à produção de textos, preparando gradativamente para a formação do indivíduo capaz de "pensar" e "fazer", ser crítico e buscar soluções;

- Sugestões de pesquisas e coletas de dados, folders, histórias em quadrinhos, jornais, revistas e programas de televisão, vídeo (...), explorando diversas temáticas sociais, políticas, ambientais e culturais;

- Leitura de textos escritos seqüenciados de partes (introdução, desenvolvimento, conclusão, parágrafos, capítulos,...) em função da complexidade dos temas escolhidos, observando o discurso direto e indireto.

\section{5 - RECURSOS}

\subsection{1 - HUMANOS}

- Direção

- Professores: - Oficina da Palavra

- Geografia 
- História

- Língua Portuguesa

- Coordenadores Pedagógicos

- Alunos

- Comunidade

- Bibliotecário (no momento apresentamos carência)

\subsection{2 - MATERIAIS}

- Jornais, revistas e outros

- Mural

- Vídeo

- Televisão

- Livros Literários e Científicos

- Cartazes

- Papéis Diversificados (pardo, fantasia,...)

- Giz, quadro de giz, cola, tesoura,...

- Biblioteca, entre outros.

\section{6 - SUGESTÕES}

\subsection{1 - ANEXO 1:}

- Sugestões de atividades que poderão ser desenvolvidas na Biblioteca do Projeto Sala de Leitura.

\subsection{2 - ANEXO 2:}

\subsection{1 - ANEXO 1 - SUGESTÕES DE ATIVIDADES QUE PODERÃO SER DESENVOLVIDAS NAS AULAS DENTRO DO PROJETO SALA DE LEITURA}

01 - Assistir Filme

A turma assistirá a um mesmo filme.

O filme será narrado em sala pelos alunos.

Cada aluno narra uma pequena parte. Os colegas corrigem ou acrescentam, quando houver falhas.

02 - Entrevista

Cada grupo de alunos escolherá uma autoridade ou especialista, para ser entrevistada sobre um tema previamente escolhido pelos grupos. Cada grupo apresentará em sala as opiniões dos entrevistados e seus argumentos.

Obs.: A entrevista pode ser também hipotética.

03 - Ouvir e Reproduzir o que ouviu

O professor lê uma notícia de jornal. Em seguida, solicitará alguns alunos que reproduzam o que ouviram, da maneira mais fiel possível.

04 - Jornal Falado

Uma vez por semana um grupo de alunos apresentará, em sala, um jornal falado, semelhantes aos telejornais, sobre assuntos previamente determinados. 
05 - Desenvolvimento do Senso Crítico

Pedir aos alunos que assistam a um determinado programa de televisão para que haja depois uma discussão, em sala, a respeito dele.

06 - Concurso de Anedotas

Realizar com os alunos um festival de anedotas, de preferência, criadas por eles mesmos.

07 - Dramatização

Sob orientação do professor os alunos encenarão em sala, um determinado texto ou trecho de uma obra lida.

08 - Conversa sobre Assunto da Redação

Um aluno lê para a turma a sua redação, seus colegas farão perguntas a respeito do assunto de seu texto e ele dará as devidas explicações.

09 - Conversa Telefônica

O aluno formará dupla com um colega.

Quando o professor os chamar, diante da turma, eles improvisarão uma conversa telefônica de dois namorados, de dois amigos, entre mãe e filha, etc.

10 - Coro Falado ou Jogral

Dividir a turma em várias equipes.

Cada equipe ensaiará uma apresentação de um texto ou de um trecho de uma obra lida, sob a forma de um coro falado ou jogral.

11 - Receita

Em dia determinado pelo professor, os alunos indicados por ele deverão apresentar, oralmente ou por escrito, aos colegas a sua receita. A do prato que mais gostam.

\section{2 - Adivinhação}

Os alunos destacados pelo professor descreverão uma pessoa (oralmente), um lugar, um objeto, uma coisa qualquer, sem dizer o nome que algum colega descubra o que está sendo descrito.

13 - Imitação

Imitar um pouco o pessoal de televisão. Cada vez que o professor achar interessante, ele interrompe a aula e anuncia: "Nossos comerciais, por favor!", indicando alguém que irá à frente para fazer uma propaganda.

14 - Ler e Interpretar Oralmente

Após ler um poema, uma frase, um pensamento, uma notícia... o aluno fará sua interpretação oralmente.

15 - Espetáculo de Variedades

Os alunos apresentarão um show com números musicais, humorismo, declamações, etc.

16 - Resumo leu.

Resumir para os colegas oralmente, uma reportagem, um conto, um romance que 
17 - Confecção de Cartazes Publicitários

Os alunos confeccionarão cartazes publicitários, propagandas, obras lidas por eles.

18 - Slogans

Criar slogans a partir de determinadas idéias do livro lido.

19 - Reportagem

Os alunos indicados pelo professor contarão a sua turma uma reportagem interessante que tenham lido em jornal ou revista.

20 - Reprodução de Trechos e Textos

Reescrever um trecho ou texto com outras palavras, conservando a idéia principal (discutir, antes, com os alunos qual é a idéia básica do trecho)

21 - Dar Finais Diferentes a um Texto Lido

Após ler um texto ou um livro, o aluno escreverá um final diferente daquele dado pelo autor.

22 - Paródia

Redigir uma paródia (em versos).

A paródia consiste na imitação caricata, zombeteira, irônica de um texto, abordando um assunto do momento.

23 - Carta

Escrever uma carta ao autor de um livro, concordando ou discordando do destino dado à determinada personagem ou sugerindo outro final para a história.

\section{4 - Programa de Rádio}

Elaborar, em grupo, um programa de rádio, com as seguintes características: Dia e horário que vai ao ar, patrocinadores; partes: a) Hora do Jovem (música da preferência dos jovens), tradução de música estrangeira, oferecimento musical. b) Hora do Amor: Recados do coração, leituras de poemas de amor, audição de músicas românticas.

\section{$25-\mathrm{Disco} / \mathrm{CD}$}

Toda classe escutará (e cantará) uma ou mais vezes, uma música previamente escolhida para:

a) Analisar a letra (conteúdo, linguagem);

b) Fazer um debate em torno do tema evidenciado na letra;

c) Escrever uma paródia da letra.

26 - Princípios de História

Inicia-se uma história, que pode ser um fato real da vida de alguma pessoa, deixando os presentes em "suspense". Em pequenos grupos, os alunos deverão encontrar um final para a história.

27 - Colagem

A partir de fotografias tiradas de revistas, os alunos, em grupos, imaginam uma colagem onde se juntam vários elementos complementares, que comuniquem uma mensagem.

Ex.: Sociedade de consumo: colagem de publicidade, restos de embalagens, etc. 


\subsection{2 - ANEXO 2 - CONSIDERAÇÕES IMPORTANTES PARA A ELABORAÇÃO DO SEU ROTEIRO}

01 - Ter o conhecimento prévio do assunto a ser trabalhado;

02 - Aproveitar as suas emoções enquanto leitor para a criação das atividades;

03 - Dividir o trabalho em três grandes momentos: Motivação Prévia, Momento da Leitura e Atividades a partir da Leitura: "ESCRITA";

04 - Propor sugestões de atividades que envolvam outras áreas do conhecimento, em parceria com a prática da leitura e escrita (interdisciplinaridade);

05 - Observar as possibilidades de se relacionar outros textos a partir do gênero, assunto, ilustração, personagens, estrutura, etc. semelhantes ao texto escolhido (intertextualidade);

06 - Ter atenção para não direcionar o trabalho a uma unidade ideológica inflexível;

07 - Propor pesquisas, participação da família, interação entre os alunos e professores nas atividades sugeridas;

08 - Proporcionar atividades dinâmicas de trabalho para que o interesse da criança e do adolescente não se perca nos primeiros momentos;

09 - Oferecer diversas atividades e atentar para que não sejam muito longas;

10 - Estimular:

- A oralidade dos alunos (propagandas, teatros, opiniões, painéis, debates, etc.);

- A criação (escrita, artística, musical, corporal, etc.).

- O aspecto crítico (resenhas, comentários, opiniões, comparações, etc.). Propor a leitura individual e a leitura compartilhada para o desenvolvimento contínuo do leitor.

11 - Considerar a diversidade das linguagens: coloquial, regional e padrão;

12 - Considerar a diversidade cultural das regiões brasileiras: música, alimentação, costumes, linguagem, roupas, folclore, etc.;

13 - Salientar no livro infanto-juvenil o papel da ilustração a partir da observação atenta, de debates direcionados, de reproduções dos próprios alunos, da análise do traço, do estilo, das cores, da dinamicidade, da ilustração, etc.

\section{7 - AVALIAÇÃO}

*Observação, participação, interesse e auto-avaliação do professor e dos alunos destacando pontos positivos e negativos.

*Destreza, ritmo e o desempenho dos participantes nas realizações das tarefas no decorrer do processo no ano letivo.

Observação:

Este Projeto é flexível, está sujeito a alterações, mudanças, conforme às necessidades dos alunos, dos professores e das disciplinas que irão atuar.

\section{2 - PROJETO DESENHANDO FORMAS}

2.1 - Identificação do Projeto

Projeto: Desenhando Formas

Coordenação: Geometria 
Matemática

Educação Artística

Local: Centro de Ensino Fundamental 01 de Sobradinho

Cronograma: Ano Letivo 2007

\section{2 - Justificativa}

Como já é do conhecimento de muitos e comprovado inclusive através de estatísticas, os alunos do ensino fundamental de $5^{\mathrm{a}}$ a $8^{\mathrm{a}}$ séries, apresentam um elevado grau de dificuldade no estudo da matemática. Segundo os estudiosos são várias as causas para estes problemas que no momento não nos cabe discorrer sobre elas.

Querendo minimizar esse problema em nossa escola, que procuraremos introduzir o projeto de geometria. Assim, teremos como eixo norteador nesse projeto a interdisciplinaridade, principalmente com as disciplinas de arte e matemática, pois as competências se compatibilizam.

\section{3 - Objetivos}

\subsection{1 - Geral}

Desenvolver capacidades cognitivas abstratas e formais, de raciocínio, de abstração, de dedução, de reflexão e de análise, bem como desenvolver habilidades para resolver problemas em diferentes campos, para ressaltar aspectos e relações da realidade não observáveis diretamente e, para permitir, antecipar e prever ações, situações ou resultados antes que se produzam ou se observem de modo a construir conhecimentos necessários para o desenvolvimento do conhecimento crítico-estético e competência artística nas diversas linguagens da arte como artes visuais.

\subsection{2 - Específicos:}

*Construção da relação de autoconfiança com a produção artística pessoal e conhecimento estético, respeitando a própria produção e a dos colegas, sabendo receber e elaborar críticas;

* Sanar as dificuldades do aluno em relação à geometria;

* Integrar a geometria a outros componentes curriculares;

*Facilitar o aprendizado da álgebra;

*Facilitar a formação de conceitos e a percepção das formas artísticas;

* Incorporar as distintas formas de expressão matemática como numérica, gráfica e geométrica à linguagem e aos modos de argumentação habituais com o propósito de comunicar-se de maneira precisa;

*Identificar formas e relações espaciais que se apresentam na realidade, analisando as propriedades e relações geométricas implicadas e sensibilizando-se com sua beleza.

\section{4 - Desenvolvimento}

\subsection{1 - Iniciação}

Reuniões com a equipe envolvida para selecionarem as competências, habilidades e procedimentos que serão desenvolvidos ao longo do bimestre.

\subsection{2 - Culminância}

Ao final dos bimestres serão realizadas amostragens das atividades desenvolvidas pelos alunos.

\subsection{3 - Sugestões}

Despertar...

*a curiosidade e interesse por averiguar a medida de alguns objetos e a duração de algumas ações. 
*o interesse e gosto pela descrição precisa de situações, orientações e relações espaciais, utilizando a linguagem básica da geometria.

*a curiosidade e interesse por identificar formas e relações geométricas nos objetos do seu cotidiano.

*a sensibilidade diante das qualidades estéticas de configurações geométricas, reconhecendo sua presença na natureza, na arte e na técnica.

\section{5 - Avaliação}

Será realizada durante o ano de 2007, no final de cada bimestre.

\section{3 - PROJETO DESPORTIVO}

\section{1 - Objetivo}

Proporcionar aos alunos a vivência em torneios, nos quais são exigidos o companheirismo, a persistência, a garra e respeito pelos colegas que jogam com ele e "contra" ele, e ainda eventualmente revelar alunos que possam defender Sobradinho em competições.

Serão disputadas as seguintes modalidades esportivas:

Handebol, Atletismo, Vôlei, Tênis de mesa e queimada, Futsal, Tênis de quadra e salto em altura.

\section{2 - Cronograma}

$1^{\circ}$ Bimestre - Festival de Atletismo

$2^{\circ}$ Bimestre - Torneio de Futsal

$3^{\circ}$ Bimestre - Torneio de Handebol

$4^{\circ}$ Bimestre - Torneio de Tênis de mesa

\section{3 - Operacionalização}

As equipes que disputarão os torneios serão as turmas da escola e ocasionalmente poderão se unir a outras para montar uma equipe só, caso não haja elementos suficientes para montar determinada equipe, sendo os jogos realizados nos turnos de estudo do aluno. definido:

Os professores atuarão como organizadores dos times e torcidas, como abaixo

- organização: apitando, arbitrando, fazendo súmulas, ajudando na entrada dos times em quadra.

- torcida: criando gritos de guerra, pompons, atuando como técnicos, etc.

\section{4 - Material Utilizado}

Todo material a ser utilizado a escola já possui, ou seja:

- Quadra

- Mesas

- Bolas

- Serviço de som

- Medalhas

\section{4 -PROJETO RECUPERAÇÃO PARALELA (DEPENDÊNCIA)}

\section{1 - Justificativa}

Visando reverter o índice de reprovação, sentimos a necessidade de elaborar este projeto.

Quando o aproveitamento do aluno é insuficiente, as causas devem ser investigadas. Comprovamos que os fatores que contribuíram foram: sociais, desinteresse dos responsáveis, apatia do próprio educando e freqüente troca de professores. 
O aluno de aproveitamento insuficiente poderá ter rendimento satisfatório se lhe proporcionarmos o tempo e as condições necessárias para atingir a sua aprendizagem.

Afim de que possamos realizar nosso trabalho contamos com a colaboração desta regional no sentido de nos oferecer os recursos humanos necessários.

\section{2 - Objetivo Geral}

- Proporcionar condições para que os alunos atinjam os objetivos propostos no planejamento anual combatendo a repetência e a evasão.

\section{3 - Objetivos Específicos}

- Oferecer em períodos freqüentes, aulas especiais (que não sejam regularmente destinados ao trabalho escolar, com todos os alunos da turma) para atender aqueles alunos que não estão acompanhando bem o processo.

- Recuperar a aprendizagem insuficiente ou deficiente.

\section{4 - Fases do Processo de Recuperação}

O processo de recuperação compõe-se das seguintes fases:

- Seleção dos alunos que apresentam dificuldade nas disciplinas: Matemática, Português, Ciências, História, Geografia, Inglês.

- Atendimento dos mesmos em horário contrário ao seu turno.

- Acompanhamento do rendimento dos alunos que estão no processo de recuperação.

\section{5 - Conteúdo da Disciplina}

Após uma análise diagnóstica da turma o professor regente determinará:

- Quais os alunos que apresentam dificuldade.

- Quais as deficiências que precisam ser trabalhadas.

- Qual o nível de reforço necessário.

- Para cada aluno

- Para cada deficiência identificada

Assim, o professor regente, terá incumbência de passar, periodicamente, ao professor da recuperação, a listagem dos conteúdos a serem trabalhados.

\section{6 - Horário de Atendimento}

Observada a carga residual dos professores os alunos serão atendidos em turno contrário ou seja:

Vespertino - das 7: 15 às 11:00

Matutino - das 13:00 às 18:00

\section{7 - Avaliação}

Caberá ao professor regente avaliar os alunos em sala de aula, através de teste escrito, orais e outras atividades conforme entendimento com o professor recuperador.

O aluno continuará no processo de recuperação enquanto for evidenciado seu desempenho insatisfatório

\section{8 - Recursos Necessários}

Para que este projeto seja implantado satisfatoriamente há necessidade da designação de 01 (um) professor de matemática, com 40 horas, por ser a disciplina que mais apresenta dificuldade para os alunos acarretando o maior índice de reprovação. 


\section{5 - PROJETO MEIO AMBIENTE}

\section{1 - JUSTIFICATIVA}

A superfície da terra está em constante processo de transformação e, ao longo de seus 4,5 bilhões de anos, o planeta registra drásticas alterações ambientais. Essas mudanças, no entanto, são provocadas por fenômenos geológicos e climáticos e podem ser medidas em milhões e até centenas de milhões de anos. Com o surgimento do homem na face da Terra, o ritmo de mudanças acelerou-se.

A escalada do progresso técnico humano pode ser medida pelo seu poder de controlar e transformar a natureza. Observa-se quanto mais rápido o desenvolvimento tecnológico, maior o ritmo de alterações provocadas no meio ambiente. As fontes de energia dominadas pelo homem, a partir do século XVIII, produzem determinadas conseqüências ao meio ambiente. Porém existem fontes alternativas que preservam o ambiente sem causar danos ao equilíbrio ecológico.

Este projeto visa informar e alertar sobre todos os agentes causadores do desequilíbrio e provocar no corpo docente a iniciativa de buscar meios que não afetem o nosso planeta e não diminua a qualidade de vida do ser humano, formando uma consciência presente e futura, encontrando soluções alternativas.

\section{2 - OBJETIVO GERAL}

Identificar as alterações ambientais causadas pela ação do homem, somadas a processos naturais que mudam o clima no mundo e proporciona uma completa revisão de nossos atuais padrões de consumo e desperdício, com estratégias para garantir um desenvolvimento sustentável.

\section{3 - OBJETIVOS ESPECÍFICOS}

- Refletir sobre o papel da tecnologia e da ciência na preservação ambiental.

- Formar a construção do saber de forma crítica e seletiva observando os agentes causadores do desequilíbrio ecológico.

- Promover discussões, entre os alunos e professores, sobre a abrangência temática: Desenvolvimento Sustentável.

- Participar de palestras que apresentam estudos, pesquisas e práticas.

- Identificar o estilo de desenvolvimento econômico adotado nos últimos séculos e suas conseqüências.

- Perceber a proposição de problemas e paradoxos para acabar com a degradação ambiental observando os objetivos econômicos e políticos.

- Valorizar e preservar os ecossistemas existentes.

\section{4 - CLIENTELA}

Alunos da $4^{\mathrm{a}}$ a $8^{\mathrm{a}}$ séries.

\section{5 - ESTRATÉGIAS}

- Textos diversos;

- Documentários;

- Palestras;

- Meios de comunicação;

- Dramatização;

- Confecção de murais;

- Sarau;

- Filmes. 
5.6 - RECURSOS

- Professores;

- Coordenadores pedagógicos;

- Data show;

- Vídeo cassete;

- DVD;

- Televisão.

\section{7 - CRONOGRAMA}

De fevereiro a dezembro de 2007.

\section{6 - PROJETO LABORATORIO DE INFORMÁTICA}

\section{1 - JUSTIFICATIVA}

As mudanças continuam correndo e as escolas precisam sofrer transformações frente a essa "nova tecnologia", palavra que vem do grego "tuctein", que significa criar, produzir, conceber, dar a luz e assim construir uma aprendizagem inovadora que leva o indivíduo a se sentir como um ser globalizado capaz de interagir e competir com igualdade na busca de seu sonho profissional.

Tornar nossos alunos integrados neste contexto é ma tarefa de grande importância, pois muitas vezes a escola torna-se o único local de acesso pra o contato nas áreas de lazer, cultura, esporte, alimentação.

A informática assim contribuirá articulando e priorizando o trabalho coletivo e crítico de construção do conhecimento, e esta construção precisa estar referendada no constante esforço de se criar ambientes de ensino, aprendizagem, interatividade e cooperatividade, tendo em vista as inúmeras possibilidades de implantação de novas técnicas de ensino.

\subsection{OBJETIVOS}

\subsubsection{GERAL}

Oportunizar os alunos o contato com a informática contribuindo para que eles desenvolvam a criatividade, o espírito crítico, o trabalho em grupo para o desenvolvimento de competências e habilidades.

\subsection{2 - ESPECÍFICOS}

- Reconhecer a informática como ferramenta para novas estratégias de aprendizagem, capaz de contribuir de forma significativa para o processo de construção nas diversas áreas;

- Identificar os principais equipamentos de informática, reconhecendo-os de acordo com suas características e funções;

- Reconhecer o papel da informática na organização da vida sócio-cultural e na compreensão da realidade, relacionando o manuseio do computador a casos reais, seja no mundo do trabalho ou na vida privada;

- Construir conhecimento utilizando para isso atividades interdisciplinares através da Internt;

- Promover situações de aprendizagem aos educandos e estimula-los a compreender as possibilidades da tecnologia de informática; 
- Estimular a aplicação do conhecimento e habilidades em uma prática reflexiva dos conceitos anteriormente adquiridos em sala de aula, para a concretização do saber e sua utilização no atendimento das necessidades individuais;

- Incorporar a informática como componente do processo ensino-aprendizagem;

- Incentivar os professores a utilizarem softwares educacionais como forma de enriquecer suas aulas;

- Criar na escola um espaço a mais para proporcionar interação aluno/professor.

\section{3 - AVALIAÇÃO:}

- Através de reuniões e discussões entre professores e coordenadores;

] - Por meio de entrevistas, questionários e sugestões de alunos;

- No desenvolvimento dos alunos nas atividades realizadas no laboratório.

\section{4 - DIVULGAÇÃO:}

- Através de cartazes;

- Através de bilhetes;

- Reuniões de pais e mestres;

- Ao NTE;

- Aos alunos em sala.

\section{5 - CRONOGRAMA:}

Durante o ano letivo em curso.

\subsection{RECURSOS NECESSÁRIOS:}

6.6.1 - HUMANOS:

- Professores;

- 02 coordenadores do laboratório com jornada ampliada, para os dois turnos (matutino/vespertino).

\subsection{2 - MATERIAIS:}

20 Computadores;

02 Impressoras;

01 Data show;

20 mesas de computador;

20 cadeiras.

\section{7 - PROJETOS DESENVOLVIDOS PELA SECRETARIA DE EDUCAÇÃ̃O APOIADOS PELO C.E.F. 01}

- Estamos dando prosseguimento aos Projetos já existentes e implantando outros, conforme relação em anexo:

1) Drogas/Sexualidade

2) Recreio Orientado

3) Oficina de Artes

4) Desenhando Formas

5) Renda Minha

6) Visitador Escolar (Programa desenvolvido pela SE)

7) Bolsa-Escola 
8) Recuperação Paralela (Dependência)

9) Sala de Leitura

10) Meio Ambiente

11) Gestão Escolar

\section{8 - PROJETO VALORES HUMANOS}

- Cronograma - De março a dezembro de 2007

- Nível de Atuação - Ensino Fundamental - alunos de $4^{\mathrm{a}}$ a $8^{\mathrm{a}}$ séries

- Local - Centro de Ensino Fundamental 01 de Sobradinho

\section{1 - Objetivo Geral:}

Implantar a prática de valores como a Amizade, o Respeito, a Justiça e a Solidariedade para melhorar o convívio, o cooperativismo e o desenvolvimento de todos, realizando com responsabilidade atividades em grupos, assumindo direitos e deveres que lhe correspondem.

\section{2 - Objetivos Específicos:}

- Desenvolver o respeito mútuo entre os alunos.

- Reconhecer ações positivas para a formação de uma sociedade mais justa.

- Facilitar o trabalho em grupo.

- Possibilitar o contato com histórias de vida em que valores foram essenciais.

- Solidarizar-se ante os problemas e necessidades de seus companheiros e da comunidade, contribuindo para a superação.

\section{3 - Desenvolvimento dos problemas:}

Cada professor ficará responsável por uma turma e em parceria com seus alunos desenvolverão atividades relacionadas aos valores humanos seguindo o seguinte cronograma:

$1^{\circ}$ bimestre - Amizade e Respeito

$2^{\circ}$ bimestre - Honestidade

$3^{\circ}$ bimestre - Justiça

$4^{\circ}$ bimestre - Solidariedade

\section{4 - AÇÕES:}

I - Num primeiro momento a ser combinado na escola, os professores trabalharão com seus alunos os textos de apoio que constam:

- Conceitos do valor trabalhado

- Biografias

- Exemplos de vida

- Frases

- Fábulas

II - Parte-se então, num segundo momento para a montagem de murais, confecção de cartazes, apresentação de músicas, encenações, etc.

III - Complementando e enriquecendo o Valor Humano trabalhado é passado um filme instigando o debate e relatos.

IV - De forma interdisciplinar será trabalhada a biografia de personalidades como: Madre Tereza de Calcutá; Betinho, Gandhi entre outros, onde o contexto histórico também será analisado. 
V - Finalizando os alunos terão que desenvolver ações solidárias, mostrando responsabilidade e engajamento no contexto social.

\section{9 - PROJETO FEIRA DE CIÊNCIAS, ARTE E CULTURA}

- Nível de atuação - Ensino Fundamental - alunos de $5^{\mathrm{a}} \mathrm{s} 8^{\mathrm{a}}$ séries.

- Local - Centro de Ensino Fundamental 01 de Sobradinho

9.1 - Objetivo Geral:

Compreender a Ciência como processo de produção de conhecimento e como atividade humana histórica associada a aspectos de ordem social, econômica, política e cultural.

\section{2 - Objetivos Específicos:}

- Relacionar o conhecimento científico à tecnologia, como meio para suprir as necessidades humanas.

- Desenvolver habilidades, valores e atitudes para participar de forma responsável na prevenção e solução de problemas.

- Realizar produções artísticas, pesquisando e explorando a linguagem cênica.

- Reconhecer, respeitar e valorizar a diversidade das manifestações culturais.

\section{3 - Desenvolvimento:}

Cada professor coordenará a atividade em uma turma, onde dentro de um ou vários temas e/ou tópicos escolhidos será desenvolvido o trabalho.

\section{4 - Culminância:}

A "Feira" ocorrerá nos dias 26 e 27 de outubro de 2006, estando previsto para o primeiro dia a montagem e abertura e para o segundo dia a abertura para visita da comunidade, apresentações teatrais e desmonte.

9.5 - Avaliação:

*Observação, participação e interesse dos alunos.

*Desempenho dos participantes nas realizações das tarefas.

OBS: Estes projetos são flexíveis, estão sujeitos a alterações, mudanças, conforme as necessidades dos alunos, dos professores e das disciplinas que irão atuar.

\section{PROJETO XADREZ NA ESCOLA}

\section{Componentes Curriculares:}

Português, matemática, ciências

\section{1-Tema}

A introdução do projeto Xadrez na Escola, levará o aluno a compreender as diversas funções do xadres, identificando o significado e movimento de todas as suas peças, estimulando, assim, o raciocínio e contribuindo também para auxiliar tomada de decisões, tão necessárias no dia a dia.

\section{2 - Justificativa}

Os alunos do ensino fundamental apresentam um elevado grau de dificuldade de concentração, atenção e raciocínio.

Querendo minimizar esse problema em nosso Estabelecimento de Ensino, procuramos introduzir o projeto de Xadrez visando também ensinar aos alunos a tomar decisões para a vida como no jogo aumentando assim sua concentração e raciocínio.

\section{3 - Objetivo Geral}


Desenvolver capacidades cognitivas de raciocínio e pensamento lógico, bem como desenvolver habilidades como: criatividade, planejamento, antecipação, atenção, autocontrole, concentração, imaginação, memória, perseverança, paciência, tomada de decisão e a inteligência geral.

\section{4- Objetivos Específicos}

- Facilitar o aprendizado da Matemática

- Conhecer o jogo

- Identificar as regras

- Perceber o raciocínio lógico

- Desenvolver as capacidades intelectuais (memória)

- Incentivar o ensino de Xadrez como atividade sócio-educativa

\section{5 - Procedimentos}

O ensino de Xadrez é desenvolvido através de uma parte teórica e uma parte prática, sendo que a parte prática é feita através de trabalho em grupo com 4 componentes: dois jogadores e dois observadores. Os observadores anotam e registram todas as jogadas.

\section{6 - $\underline{\text { Avaliação }}$}

Através da prática do jogo, através de testes escritos e campeonatos realizados durante o ano letivo.

\section{1 - PROJETOS INDIVIDUAIS/PARALELOS:}

\section{1 - *Projeto de leitura}

Objetivo - Colocar o aluno em contato com diferentes tipos de texto

Período de duração - anual

Ações - Participação em concursos literários diversos

Público-Alvo - Professores, alunos e pais

Responsável - Equipe pedagógica e professores das $4^{\mathrm{a}}$ séries

\section{2 - *Arte e Ofício}

Objetivos:

- Propiciar ao aluno contato com diferentes expressões artísticas (teatro, música, pintura).

- Promover a interdisciplinaridade, tendo como fio condutor a arte.

Período de Duração - Dois semestres

Público-Alvo: Professores, alunos e pais

Responsável: Equipe pedagógica e professores.

\section{3 - * Noções Básicas da Língua de Sinais para a comunicação diária}

Objetivo - Promover a comunicação básica entre ouvintes e não ouvintes.

Período de duração - Primeiro semestre letivo

Público-Alvo - Alunos e professores das $4^{\mathrm{a}}$ séries (mat/vesp).

Responsável - Professores das $4^{\mathrm{a}} \mathrm{s}$ séries e Prof. Patrícia (D. A.)

\section{4 - *Festival de Música Internacional}

\section{5 - *Projeto de Cordel e Xilogravura}




\section{2 - PROJETO SALA AMBIENTE}

\section{1 - Justificativa:}

A sala ambiente tem por finalidade dotar o corpo docente e discente de maior suporte técnico e pedagógico para que a educação se processe em ambiente adequado, dinâmico e interativo, para prover a aprendizagem significativa.

\section{2 - Objetivos:}

- Proporcionar ambiente agradável para melhor assimilação de conhecimentos específicos;

- Facilitar atividades diversificadas;

- Estimular a interdisciplinaridade e transversalidade;

- Divulgar a pluralidade cultural da nossa sociedade;

- Favorecer a disposição de materiais para o desenvolvimento das competências previstas;

\section{3 - Responsáveis:}

- Diretora e Vice-Diretor

- Assistência Pedagógica

- Coordenadores

- Professores

- Auxiliares em educação

- Discentes

- Comunidade Escolar

- Conselho Escolar

- APM

\section{4 - Público Alvo} séries.

O Público alvo que se pretende atingir são os corpos docente e discente de $5^{\mathrm{a}}$ a $8^{\mathrm{a}}$

\section{5 - Recursos}

- Espaços Físicos

- Móveis

- Materiais didáticos específicos

\section{6 - Manutenção dos Recursos}

- Cada sala deverá ter sua chave;

- O Professor deverá ter sua chave;

- Os componentes da Direção deverão estar, efetivamente, no pátio durante a troca de horário, até que todos assimilem os hábitos e a disciplina proposta;

- As salas e blocos devem ser identificados com clareza, por disciplina e por professor;

- Cabe ao professor a manutenção do ambiente (organização e limpeza)

12.7 - Operacionalização

Descrição do funcionamento das salas ambientes:

- Distribuição de salas por bloco:

Bloco A - Laboratório, Biblioteca, Sala de Vídeo, Sala de Artes;

Bloco B - Salas de aula 
Bloco C - salas de aula

\section{8 - Ambientes Especiais}

Os espaços sala de vídeo, biblioteca, laboratório, quadras, sala de múltiplas funções, devem ser otimizados tanto por seus coordenadores quanto pela busca de sua utilização pelos demais docentes.

Sugere-se que sejam planejadas, antecipada e constantemente, atividades diversificadas nos laboratórios da escola, em todas as disciplinas e entre estas.

\section{9 - Do Ambiente por Disciplina}

Cada sala de aula, a partir de então, deverá incorporar a disciplina com a qual se relaciona de modo que a sala seja um retrato tanto do docente quanto da disciplina que ministra.

Acredita-se que a composição deste ambiente se dará gradativa e proporcionalmente no empenho dado pelo professor regente. Portanto, professores e direção, deverão incentivar a disponibilizar os recursos necessários, na medida do possível.

\subsection{0 - NORMATIZAÇÃO PARA O CORPO DOCENTE}

- Durante a troca de sala o professor não deverá se ausentar da sala;

- Ao se ausentar da sala durante o recreio, ou em outra situação, o professor deverá manter a sala trancada;

- Nos dias em que o professor não estiver na sala (atraso, falta justificada, abono, atestado médico, etc), contaremos com o apoio dos coordenadores e direção.

OBS:

- O professor deverá orientar constantemente,representantes de turma para agirem no caso de sua ausência;

- Será de responsabilidade do professor, no seu horário, os alunos de sua turma de modo que estes só poderão transitar pela escola munido de crachá do professor;

- O professor tem o dever de encaminhar os casos de alunos ausentes em sua sala, após os 15 minutos de tolerância.

\subsection{1 - NORMATIZAÇÃO PARA O CORPO DISCENTE}

- O aluno tem no máximo 5 minutos, para troca de sala. Em caso de ultrapassar este tempo, sofrerá sanções conforme discriminação abaixo:

a) Na $1^{\text {a }}$ semana: $\mathrm{O}$ aluno será advertido oralmente pelo professor;

b) A partir da $2^{\mathbf{a}}$ semana: $O$ aluno será encaminhado à Direção para as devidas providências disciplinares, devendo em seguida, retornar à sala de aula;

- Durante a troca de sala, o aluno não deverá ir ao banheiro. Em caso de maior necessidade, o aluno deverá estar munido de crachá do professor regente;

- O trânsito de alunos nos pavilhões, será observado pelo corpo da direção que o fará cumprir todas as normas;

- O aluno é o maior responsável pelo seu material escolar. Em caso de perda ou esquecimento, a responsabilidade será imputada ao mesmo. professor;

- O aluno, inclusive o representante, só será atendido na Direção com o crachá do

- Para o intervalo do recreio: a troca de sala se dará antes do recreio, onde serão batidos dois sinais - o primeiro para a troca de sala; o segundo para o recreio. Ao final do recreio, o aluno se dirige imediatamente para sua sala; (a tolerância será de 5 minutos). 


\subsection{2 - Avaliação}

Propõe-se que as avaliações específicas do projeto, salas ambientes, sejam periódicas e constantes, priorizando o refazer do que não está atendendo as perspectivas propostas.

\subsection{3 - Divulgação}

A troca de experiências dar-se-á por intercâmbio, primeiramente com a comunidade escolar, por meio de cartas, bilhetes, reuniões, convites para eventos, por ser para com ela nosso compromisso maior.

\section{BIBLIOGRAFIA}

Lei de Diretrizes e Bases da Educação

Regimento da Secretaria de Educação

Estratégias de Matrícula

Currículo de Educação Básica das Escolas Públicas do Distrito Federal: ensino fundamental $5^{\mathrm{a}}$ a $8^{\mathrm{a}}$ série. 2.ed./Secretaria de Estado de Educação., 2002.

Sugestões de pais e servidores do C.E.F. 01

FRANKLIN, Benjamin. Capacidades desenvolvidas pelo Xadrez. 
ROTEIRO DE ENTREVISTA

INFORMANTES: PROFESSORES/AS DE CEFS DA REDE PÚBLICA DO DF

Formulário $n^{\circ}$.

Nome do (a) entrevistador (a):

Nome do (a) informante:

CEF:

Data da entrevista:

Duração da entrevista: a) início:

hs

b)término:

hs

\section{I - PERFIL SÓCIO-ECONÔMICO}

1.Assinale com $x$ sem fazer pergunta.

Sexo: $1 .($

) Masculino

$(\cdots)$ Feminino

2.Qual é a idade do senhor(a)?

Idade: 1.( ) Até 18 anos

2. ( ) De 19 a 24 anos

3. ( ) De 25 a 30 anos

4. ( De 31 a 36 anos

5. ( ) De 37 a 42 anos

6. ( ) De 43 a 48 anos

7. (.) De 49 a 54 anos

8. ( ) Mais de 54 anos

9. (: Sem resposta / Não sabe

3.Qual é o estado civil do senhor(a)?

Estado civil: $\quad$ 1. ( ) Solteiro

2. ( ) Casado

3. ( ) Separado (desquitado / divorciado)

4. ( ) Viúvo

5. ( ) Outro: Qual?

6. ( ) Sem resposta / Não sabe

4.Assinale com $\mathrm{x}$ sem fazer pergunta.
Cor / raça:
1. ( ) Preta
2. ( ) Branca
3. ( ) Parda
4. ( ) Indígena
5. ( ) Amarela
6. ( ) Outra: Qual?
7. ( ) Sem resposta/Não sabe 
5.Qual é a religião do senhor(a)?

Religião:
1. ( ) Católica
2. ( ) Protestante / Evangélica
3. ( Espírita
4. ( Religiões afro-brasileiras (umbanda / candomblé etc)
5. ( ) Outra: Qual?
6. ( Sem religião
7. ( Sem resposta / Não sabe

6.Qual é o grau de escolaridade do senhor(a)? Escolaridade:
1. ( ) $2^{\circ}$ Grau - Curso Normal / Pedagógico
2. ( Superior completo
3. ( ) Superior completo
4. ( ) Pós-graduação
a. ( Especialização: Área:
b. ( ) Mestrado: Área:
c. ( ) Doutorado: Área:
d. ( ) Outra: Qual?
5.( ) Sem resposta / Não sabe

7.Qual é a renda familiar do senhor(a)? Renda Familiar ${ }^{1}$
1.( ) Até 3 salários mínimos ( $\$ 900,00)$
2. ( ) Mais de 3 a 6 salários mínimos ( $\$ 1,800,00)$
3. ( ) Mais de 6 a 9 salários mínimos ( $R \$ 2.700,00)$
4. ( ) Mais de 9 a 12 salários mínimos ( $\$ 3.600,00)$
5. ( ) Mais de 12 a 15 salários mínimos $(\mathrm{R} \$ 4.5000,00)$
6. ( ) Mais de 15 a 18 salários mínimos ( $R \$ 5.400,00)$
7. ( ) Mais de 18 a 21 salários mínimos ( $\$$ 6.300,00)
8. ( . Mais de 21 a 24 salários mínimos $(\mathrm{R} \$ 7.200,00)$
9. ( Mais de 24 salários mínimos
10. ( Sem resposta/Nã̃o sabe

8.Qual é o tempo de serviço que o senhor(a) tem como professor?

Tempo de serviço como professor: 1. ( ) Até 02 anos

2. ( ) Mais de 02 a 06 anos

3. ( ) Mais de 06 a 10 anos

4. ( ) Mais de 10 a 14 anos

5. ( ) Mais de 14 anos

6. ( ) Sem resposta / Não sabe

'Valor em fevereiro / 2006: R\$300,00 
9.Qual é o tempo de trabalho do senhor(a) do SEEDF?

Tempo de trabalho na FEDF: 1.( ) Até 02 anos

2. ( ) Mais de 02 a 06 anos

3. ( ) Mais de 06 a 10 anos

4. ( ) Mais de 10 a 14 anos

5. ( ) Mais de 14 anos

6. () Sem resposta/Não sabe

10.Qual é o tempo de trabalho que o senhor(a) tem neste Centro de Ensino?

Tempo de trabalho neste Centro de Ensino: 1. ( ) Até 02 anos

2. ( ) Mais de 02 a 06 anos

3. ( ) Mais de 06 a 10 anos

4. ( ) Mais de 10 a 14 anos

5. ( ) Mais de 14 anos

6. ( ) Sem resposta / Não sabe

11. Local de moradia no DF / Entorno:

\section{II - PERFIL POLÍTICO-IDEOLÓGICO}

12. O sr (a) participa ou já participou de alguma associação comunitária (associação de moradores, prefeitura comunitária, clube esportivo etc)?
1. ( ) $\operatorname{Sim}$
2. ( ) Não

13. Se sim:

Qual?

Por que?

14. O sr (a) participa ou já participou de algum movimento social (negros, mulheres, ambientalistas, homossexuais etc)?
1. ( ) Sim
2. ( ) Não

15. Se sim:

Qual?

Por que?

16. O senhor já participou de alguma entidade religiosa?
1.Sim(
2.Não( 
17. Se sim:

Qual?

Por que?

18. O sr (a) é filiado (a) ao SINPRO/DF (Sindicato dos Professores do DF)?

Por que?
1. ( ) $\operatorname{Sim}$
2. ( ) Não

19. Se sim: Tempo de filiação no SINPRO: 1. ( ) Até 1 ano

2. ( ) Mais de 1 até 2 anos

3. ( ) Mais de 2 até 4 anos

4. ( ) Mais de 4 até 6 anos

5. ( ) Mais de 6 até 8 anos

6. ( ) Mais de 8 até10 anos

7. ( ) Mais de 10 anos

8. ( Sem resposta/Não sabe

20.0 sr (a) ocupa ou já ocupou algum cargo no sindicato?

1. ( ) Sim

21. Se sim: Qual?

1.

2.

3.

22. O SINPRO tem realizado greves desde os anos 1980 . Nomeie tres dos principais resultados dessas greves em relação aos direitos dos associados/professores: 1.

2.

3.

23. O sr (a) é filiado a algum partido político?

1. ( ) Sim
2. ( ) Não

Período: de

Período: de

Período: de

a 
24. Se sim: Qual? 1. ( ) PMDB

2. ( ) PT

3. ( ) PDT

4. ( ) $\mathrm{PSDB}$

5. ( ) $\mathrm{PC}$ do $\mathrm{B}$

6. ( ) PV

7. ( ) $\mathrm{PSB}$

8. ( ) PCB

9. () PSC
10. ( ) PTB

11. ( ) PCO

12. ( ) PSTU

13. ( ) PPS

14. ( ) PFL

15. ( ) PSOL

16. ( ) Outro: Qual?

17. ( ) Sem resposta/Não sabe

25. O sr (a) é militante de algum partido político?

$$
\text { 1. ( .) Sim }
$$

2. ( ) Não

10. () PTB

11. ( ) $\mathrm{PCO}$

12. ( ) PSTU

13. ( ) PPS

14. ( ) PFL

15. ( ) PSOL

16. ( ) Outro: Qual?

17. () Sem resposta/Não sabe

\section{III - ESCOLA E COMUNIDADE}

27. Este Centro de Ensino realiza algum trabalho em parceria com a sociedade civil?
1. ( . ) Sim
2. ( ) Não

28. Se sim: Quais organizações sociais participam desta parceria?

1. ( ) Movimentos sociais

2. ( ) Associações civis (sindicatos, igrejas, clubes etc)

3. (. ) ONGs

4. ( ) Empresariado

5. ( ) Outro: Qual?

6. () Sem resposta/ Não sabe

29. Se sim: Que tipo de trabalho tem sido desenvolvido? 
29. Enumere as estratégias que este Centro de Ensino utiliza para integrá-lo na comunidade. a) Pais:

b) Vizinhança:

31. Os pais participam das atividades da escola?

$$
\text { 1. ( ) Sim 2.( ) Não }
$$

Por que?

32. Se sim: De que maneira os pais participam neste Centro de Ensino?

33. Este Centro de Ensino incentiva a participação dos pais?

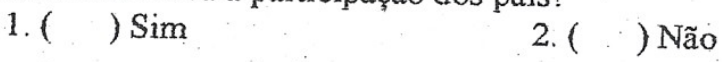

Por que?

34. Se sim: Aponte as três principais medidas adotadas por este Centro de Ensino para incentivar a participação dos pais

1

2.

3

IV - ESCOLA, DEMOCRACIA E CIDADANIA

35. O que significa para o sr (a) ser cidadão no Brasil? 
36. Que significado tem direitos humanos para o $\mathrm{sr}(\mathrm{a})$ ?

37. O sr (a) conhece os seus direitos de cidadão (ã)?
1. ( ) Sim
2. ( ) Não

38. Se sim: Quais são esses direitos?

39. O sr (a) luta por seus direitos?
1. ( ) Sim
2. ( ) Não

40. Se sim: Como o sr (a) luta por seus direitos?

41. Este Centro de Ensino está preocupado em formar cidadãos/cidadãs?
1. ( ) Sim
2. ( ) Não

Por que?

42. Que atividades vem sendo desenvolvidas neste Centro, tendo em vista a formação para a cidadania?

43. O que significa para o $\mathrm{sr}$ (a) viver em uma sociedade democrática?

44. No Brasil há democracia?
1. ( ) Sim
2. ( ) Não 
45. Neste Centro de Ensino há práticas democráticas?

$\begin{array}{ll}\text { Por que? } & \text { 1. ( ) Sim }\end{array}$

\section{Se sim: Quais?}

47. Dê alguns exemplos de medidas e/ou atividades desenvolvidas neste Centro de Ensino que expressam uma política democrática:

1. Na gestão do Centro:

2. Na atitude do professores:

3. $\mathrm{Na}$ atitude dos alunos:

4. Na participação dos pais:

5. Nos eventos da escola:

6. Outras situações? Quais?

\section{V-ESCOLA E EDUCAÇÃO EM DIREITOS HUMANOS}

48. O que o sr(a) entende por educação em direitos humanos? 49. O sr (a) conhece alguma política voltada para a educação em direitos humanos no
Brasil?
1. ( ) $\mathrm{Sim}$
2. ( ) Não 
50. Se sim: Qual?

51. O sr(a) conhece o Plano Nacional de Educação em Direitos Humanos?
1. ( ) Sim
2.( ) Não

52. Se sim: Qual é a importância deste Plano?

53. Se sim: Qual é a melhor maneira para conseguir sua implementação efetiva na educação básica ( $1^{\circ}$ e $2^{\circ}$ graus) ?

54. Na sua opinião, este Centro de Ensino reconhece os alunos (as) como sujeitos de direitos?

Por que?
1.( ) Sim
2. ( ) Não

55. Na sua opinião, este Centro de Ensino tem compromisso com a promoção de uma cidadania ativa e participativa junto aos alunos?

Por que?
1. (. ) Sim
2. ( ) Não

56. Que importância tem incentivar os (as) alunos (as) a adotar atitudes, sentimentos e práticas sociais que favoreçam o reconhecimento da igualdade de direitos e o respeito das diferenças? 
57. Enumere de um a três, por ordem de importância, os principais problemas que o sr (a) identifica neste Centro de Ensino.

( ) Discriminação existente em relação à sexualidade

( ) Discriminação existente em relação à raça / etnia

) Conflito entre os sexos

Violência interpessoal entre os alunos

) Violência interpessoal entre os professores e alunos

) Discriminação em relação à situação sócio-econômica dos alunos

) Presença de uso de drogas entre os alunos

) Rejeição do Centro de Ensino pela comunidade da vizinhança

) Outros: Quais?

58. Como o sr(a) lida com as situações de conflito e/ou violência em sala de aula?

59. Enumere em escala de 0 a 5 em medida o sr (a) se importa com as seguintes atitudes na vida cotidiana.

Escala: $0=$ nenhuma $1=$ muito pouca $\quad 2=$ pouca $\quad 3=$ média $\quad 4=$ média superior $5=$ máxima

\begin{tabular}{|c|c|c|c|c|c|c|}
\hline \multirow{2}{*}{\multicolumn{7}{|c|}{$\begin{array}{l}\text { ATTTUDES } \\
\text { Respeito em relação ao outro } \\
\text { Solidariedade com as }\end{array}$}} \\
\hline & & & & & & \\
\hline Solidariedade com as outras pessoas & 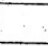 & $\therefore$ & & & & \\
\hline Cooperação na vida familiar e profissional & & & & & & \\
\hline Indignidade diante das injustiças em geral & & & & & & \\
\hline $\begin{array}{l}\text { Discriminação frente diferenças de raça, sexo, } \\
\text { geração, religião etc }\end{array}$ & & & & & & \\
\hline Opressão frente aos mais fracos & $\therefore$ & & & & & \\
\hline Compreensão dos problemas dos outros & & & & & & \\
\hline $\begin{array}{l}\text { Intolerância diante dos atos das pessoas que } \\
\text { não aprova }\end{array}$ & & & & & & \\
\hline Crítica diante da realidade & 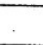 & & & & & \\
\hline Criatividade no modo de viver & & & & & & \\
\hline Autonomia para agir & & & & & & \\
\hline Participação na vida social, cultural e política & & & & & & \\
\hline
\end{tabular}


60. Enumere em escala de 0 a 5 a importância que o sr(a) dá aos seguintes valores:

Escola: $0=$ nenhuma $1=$ muito pouca $\quad 2=$ pouca $\quad 3=$ média $\quad 4=$ média superior 5= máxima

\begin{tabular}{|l|l|l|l|l|l|l|}
\hline VALORES & 0 & 1 & 2 & 3 & 4 & 5 \\
\hline Dignidade & & & & & & \\
\hline Paciência & & & & & & \\
\hline Bondade & & & & & & \\
\hline Coragem & & & & & & \\
\hline Altruísmo (estar a serviço da humanidade) & & & & & & \\
\hline Amor & & & & & & \\
\hline Amizade & & & & & & \\
\hline Sabedoria & & & & & & \\
\hline
\end{tabular}

\section{VI-EDUCAÇÃO EM DIREITOS HUMMANOS E PROJETO POLÍTICO -PEDAGÓGICO}

61. Na sua opinião, o projeto político-pedagógico deste Centro de Ensino está comprometido com a educação em direitos humanos?

$$
\text { 1. ( ) Sim }
$$

2. ( ) Não

Por que?

62. a)Quais são as finalidades sociais desse centro de ensino?

b) Quais são as finalidades culturais deste centro de ensino?

c) Quais são as finalidades políticas desse centro de ensino?

d) Quais são as finalidades profissionais deste centro de ensino? 
e) Quais são as finalidades humanísticas deste centro de ensino?

63. Como o sr(a) avalia o funcionamento da estrutura pedagógica deste Centro de Ensino nas seguintes dimensões:

a) Constituição e distribuição do poder interno (direção $X$ professores e funcionários; direção $X$ aluinos; professores $X$ alunos etc.)

b) Processo de ensino - aprendizagem (relação professor/ alunos (as) em sala de aula, tendo em vista o processo de conhecimento)

64. Como o sr(a) avalia o funcionamento da estrutura administrativa deste Centro de Ensino nas seguintes dimensões:

a) Gestão de recursos humanos (professores e funcionários administrativos)

b) Gestão dos recursos físicos (infra-estrutura da escola)

c) Gestão dos recursos finnanceiros (verbas institucionais)

65. Como o sr(a) avalia o currículo deste Centro de Ensino nas seguintes dimensões:

a) Conteúdo das disciplinas ${ }^{2}$ (tópicos do programa de cada disciplina)

b)Metodologia utilizada em sala de aula (recursos didático-pedagógicos)

${ }^{2}$ Disciplinas ministradas de quinta à oitava série: língua portuguesa, matemática, língua estrangeira moderna, geografia, história, ciências naturais, ensino religioso, educação física e artes. 
c)Recursos de ensino (espaços apropriados às disciplinas, recursos materiais, recursos áudio-visuais etc.)

d) Relação pedagógica (relacionamento aluno/professor no processo de ensino/aprendizagem)

e) Avaliação (momento de reflexão sobre os resultados alcançados em cada disciplina)

f) Visốes de mundo, (perspectiva conservadora $X$ progressista), normas (regras sociais e culturais) e valores dominantes (orientação ética, moral, política e ideológica dos professores) no processo de ensino/aprendizagem

66.Como é organizado o calendário escolar (dias letivos, férias, feriados, datas de avaliação, reuniões técnicas etc) neste Centro de Ensino?

67.Como o sr(a) avalia este calendário escolar?

a) Pontos positivos:

b) Pontos negativos:

68. Qual é sua opinião sobre o processo de decisões tomadas neste Centro de Ensino? 
69. O sr(a) tem críticas a fazer a respeito deste processo de decisões?70. Se sim: Quais?

$$
\begin{array}{ll}
\text { 1. ( ) } \operatorname{Sim} & \text { 2.( ) Não }
\end{array}
$$

70. Se sim: Quais?

71.Como o $\operatorname{sr}(\mathrm{a})$ avalia as condições de trabalho dos professores (horário de aulas, tempo para preparar as aulas, salário, etc.) neste Centro de Ensino?

72.Quais os principais problemas enfrentados pelos (as) professores (as) deste Centro de Ensino?

73.Como estes problemas tem sido resolvidos?

74.Este Centro de Ensino realiza uma avaliação anual do projeto político-pedagógico?

Por que?

1. ( ) Sim

2. ( ) Não

75. Se sim: Assinale: 
a)Pontos positivos desta avaliação:

b)Pontos negativos desta avaliação:

76. O sr(a) gostaria de comentar mais algum aspecto importante que não foi abordado? 